Portland State University

PDXScholar

\title{
Regulating Pavement Dwellers: the Politics of the Visibly Poor in Public Space
}

Lauren Marie Larin

Portland State University

Follow this and additional works at: https://pdxscholar.library.pdx.edu/open_access_etds

Part of the Speech and Rhetorical Studies Commons, and the Urban Studies and Planning Commons Let us know how access to this document benefits you.

\section{Recommended Citation}

Larin, Lauren Marie, "Regulating Pavement Dwellers: the Politics of the Visibly Poor in Public Space" (2017). Dissertations and Theses. Paper 3471.

https://doi.org/10.15760/etd.5355

This Dissertation is brought to you for free and open access. It has been accepted for inclusion in Dissertations and Theses by an authorized administrator of PDXScholar. Please contact us if we can make this document more accessible: pdxscholar@pdx.edu. 
Regulating Pavement Dwellers: The Politics of the Visibly Poor in Public Space

\author{
by
}

Lauren Marie Larin

A dissertation submitted in partial fulfillment of the requirements for the degree of

\author{
Doctor of Philosophy \\ in \\ Urban Studies
}
Dissertation Committee:
Lisa Bates, Chair
Gerald Sussman
Maura Kelly
Robert Liebman

Portland State University

2017 
(C) 2017 Lauren Marie Larin 


\begin{abstract}
Many researchers argue the increasing reliance on sit/lie ordinances to regulate homeless people's use of public space is one in a suite of neoliberal policies that shape the geographies of public space in cities to serve the needs of global capital. However, these policies are developed at the local, not global, level as specific actors make claims in the public sphere that communicatively shape policy formation. Through comparative case study, this research asks, how do different actors, situated in specific local and global contexts, influence the adoption of sit/lie ordinances?
\end{abstract}

I examine two cases of policymaking in Portland and San Francisco. I use discourse analytic strategies and thematic coding of newspapers, archival documents, and key informant interviews to look at policy-making processes as they occur in their political, social, and economic contexts. I focus especially on the role of language in policy-making, policy-making arenas, and actions of grassroots actors, drawing from three interdisciplinary literatures to develop an explanatory theory of policy-making.

I find the four interrelated explanatory factors in policy-making were: the actors (neoliberal and right-to-the-city); the tactics they use; the policy talk they use; and the policy arenas. First, political processes provide windows of opportunity and determine arenas for political activities. The different policy arenas (citizen election, committee, council led, litigation, etc.) influence the audience that the actors care about, and thus the policy talk. Additionally, elected officials have a determining effect on which arenas they use, that in turn structures the opportunities for policy talk. 
Second, the arena influences the depth to which resisters can discuss the issues with the wider public and decision-makers. This may explain why the right-to-the-city frame may not have been used as much as the academic literature might suggest. Resisters find it much harder to use this framing with the general public or elected officials because it takes too much time to explain to those unfamiliar. Instead, they rely more on concepts that may be more familiar like the dependent poor and unequal impact of the law on minority groups.

Third, I find local actors have different positions in the global economy, however on the local level their different avenues and strategies of involvement are due to local conditions rather than global ones. The location in the global political economy seems to be less important than local political decision making contexts and the actions of individuals who are locally powerful due to their economic status and political connections. This suggests room for resisters to use local politics to resist these ordinances, without having to take on the entire global economy.

Finally, actors use different narratives to influence decision makers and each other, responding and shifting to competing frames over time. The change over time is important, as it shows how policy debates change based on influences from different actors. My findings suggest the framing of the original necessity for the policy can influence the policy trajectory, but actors can and do respond and successfully shift policy talks over time. The dissertation concludes with additional implications for grassroots practice based on these theoretical findings. 


\section{Dedication}

To all those who are sleeping outside tonight, and those fighting so they can come inside.

and

My partner in life Michael Bullman, for being my rock through each step of this journey. Here is to many more journeys together without a dissertation in progress in the background.

My parents John Larin and Cindy Bannister who told me from a young age I had to be the first person in our family to go to college. I have a feeling this isn't what they meant, but it is what they got.

My grandmothers Audrey Larin and Helen Bannister, for teaching me to read, one Dr. Seuss and Disney book at a time. My grandfathers Edward Larin and John Bannister for teaching me stick-to-itiveness.

My sister, Penny Larin, for not letting me give up. 


\section{Acknowledgements}

My deepest appreciation goes out to my chair, Dr. Lisa Bates for being a thought partner, guide, and constant source of encouragement to find my own voice. I would also like to thank my committee members Drs. Bob Liebman, Gerry Sussman, and Maura Kelley for your guidance and more conversations over coffee than I can remember. Ann Greenberger provided insightful editing services. Thanks to all the community members who agreed to be interviewed, for sharing your knowledge with me and the world.

A number of other faculty and staff at Portland State University were also ardent supporters. Thanks to Dr. Dana Lundel for keeping me going, Dr. Ellen Bassett for pushing me, Dr. LeAnne Serbulo for helping shape my early thoughts, and Dr. Richard White and Dr. Shanna Eller for hiring me over and over.

Thanks also to the smart ladies who were a constant source of support, kicks in the pants, ideas, good food, and laughs when they were most needed - especially Drs. Moriah McSharry McGrath and Nicole Iroz-Elardo. The Writers Interest Group at Portland State University read and responded to many, many versions of this dissertation, special thanks to Dr. Gretchen Luhr, Dr. Marianne Ryder, and Peter O'Connell for your fabulous metaphors and stories. Thanks to Dr. Louise Dunlap for sharing your feedback process with us.

Last but not least, thanks to my family for whom this is dedicated. 


\section{Table of Contents}

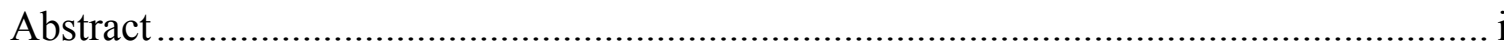

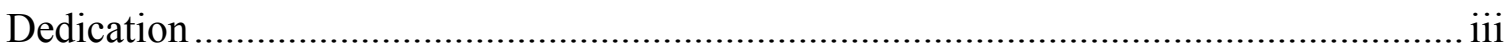

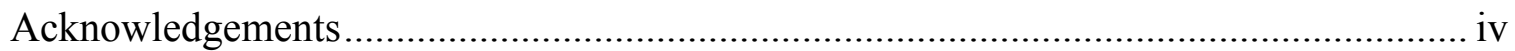

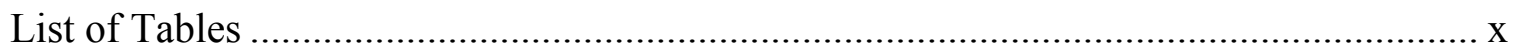

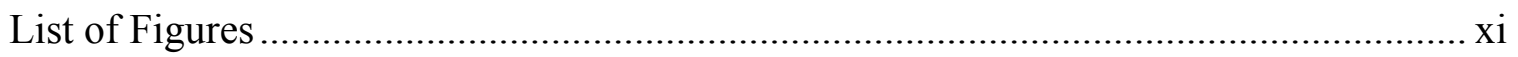

Chapter 1: Introduction and Problem Statement........................................................ 1

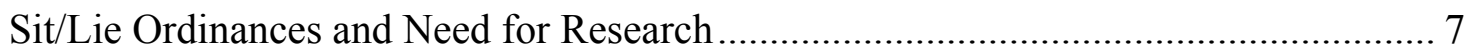

Rise of sit/lie ordinances to control homeless people ............................................. 8

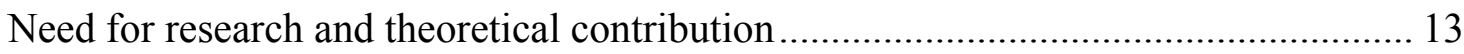

Chapter 2: Literature Review and Conceptual Framework ............................................ 16

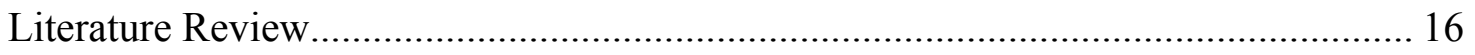

The Neoliberal City and the Right to the City: The Actors ....................................... 16

Roll-out neoliberalism and homelessness policy ………........................................ 17

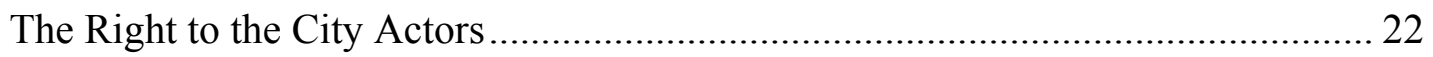

Social Movements: Political process, resources, framing, and motivation .............. 27

The role of discourse in the policy process and interpretive policy analysis............ 34

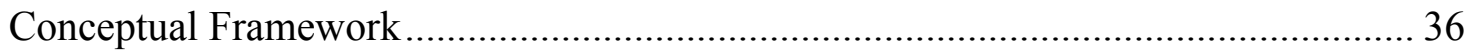

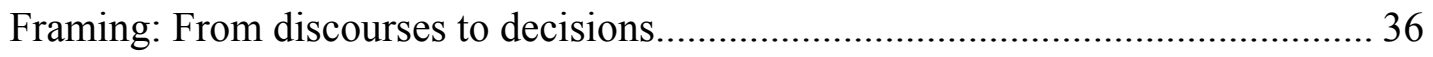


Discourses on the social question of homelessness

Chapter 3: Research Design and Methods.....

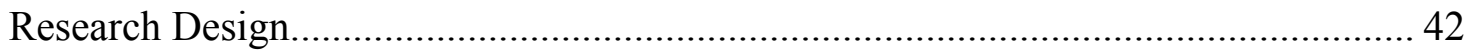

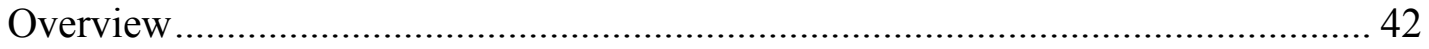

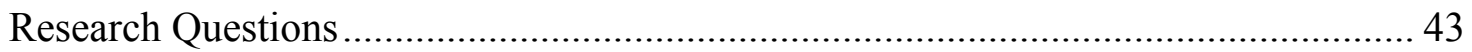

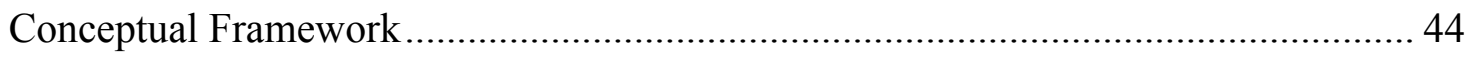

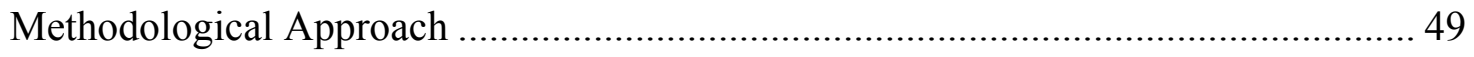

Comparative Case Study Approach ............................................................... 49

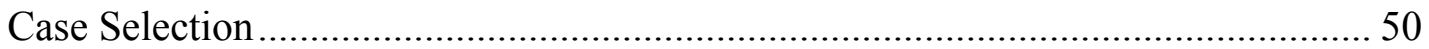

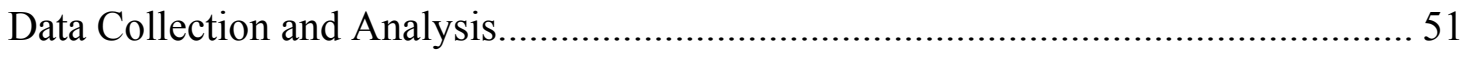

Data Collection Protocol................................................................................. 52

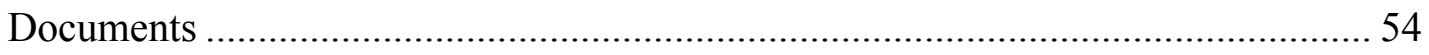

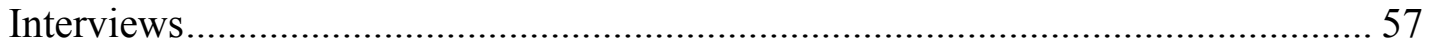

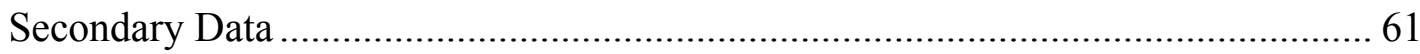

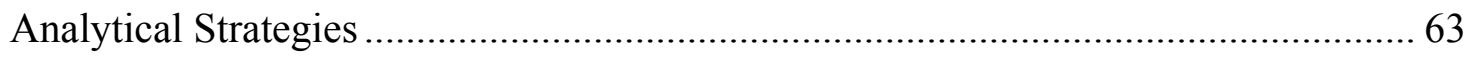

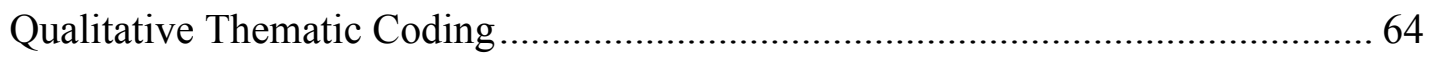

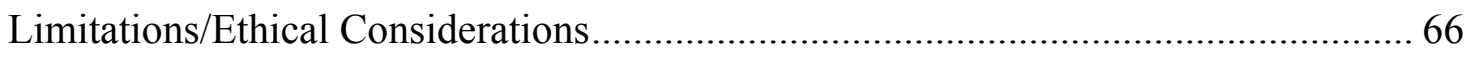

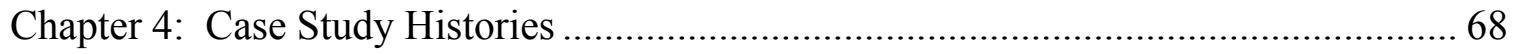

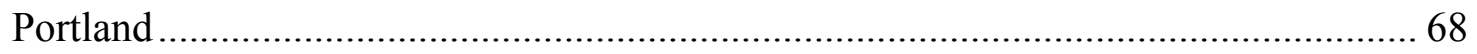


Economy and Form of Government

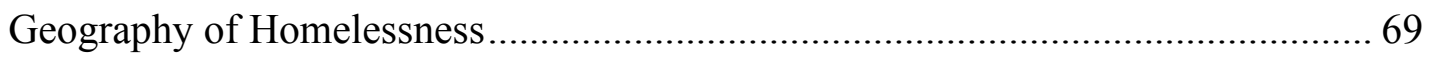

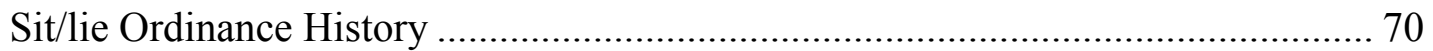

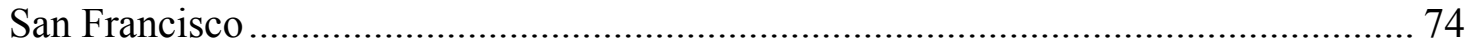

Economy and Form of Government .............................................................. 74

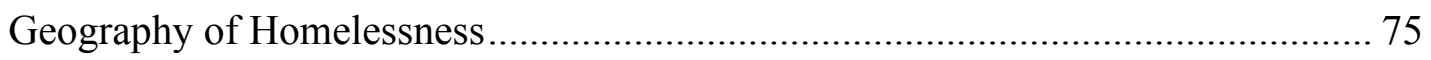

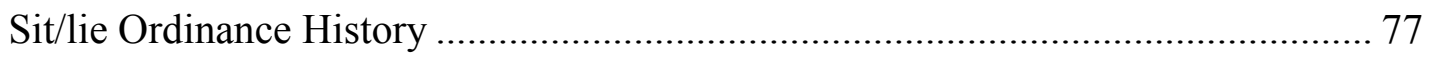

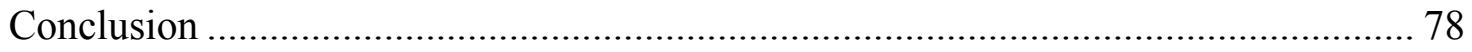

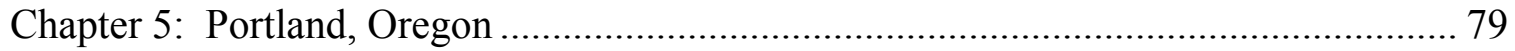

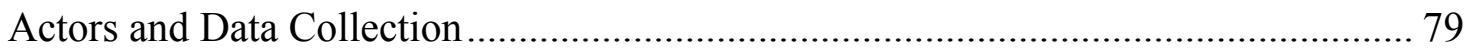

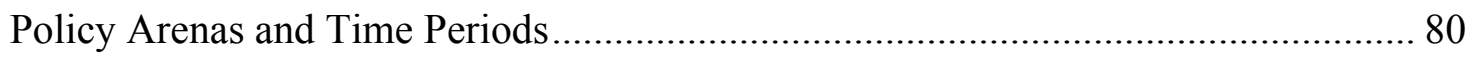

2001-2002: Administrative Rewrites To Enforce Laws Against the Poor .................. 81

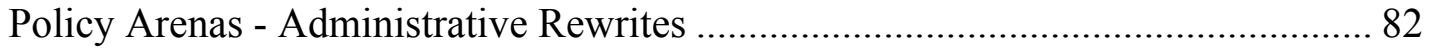

The Policy Discourses - Administrative Rewrites .............................................. 83

2002 - 2005 Legal Challenges and New Laws.................................................... 86

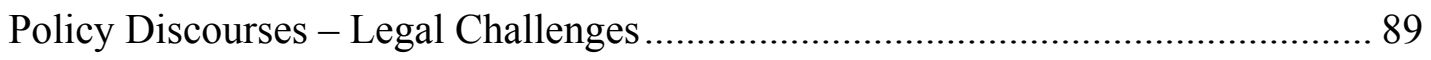

2006-2008 Citizen Stakeholder Involvement ............................................... 91

Policy Arena - Citizen Advisory Committee ......................................................... 92

Policy Discourses - Citizen Advisory Committee............................................. 92 


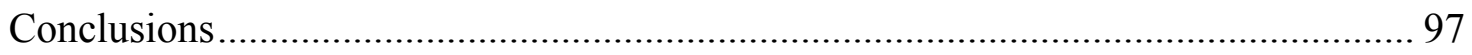

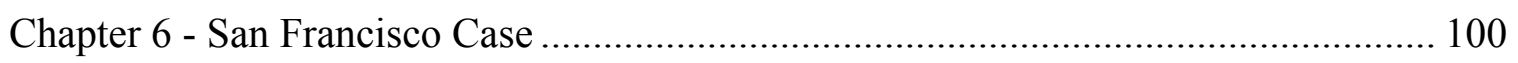

Origin Story and Historical Context ................................................................... 101

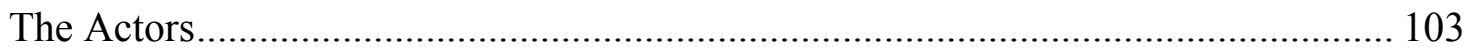

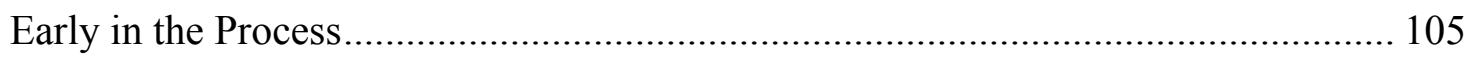

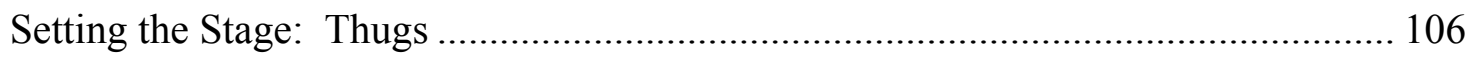

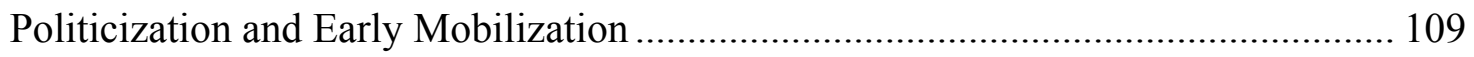

A Useful Tool or a Discriminatory Law? ......................................................... 115

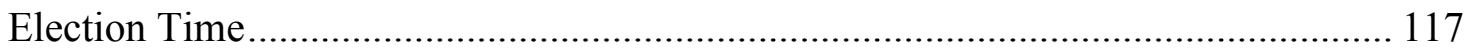

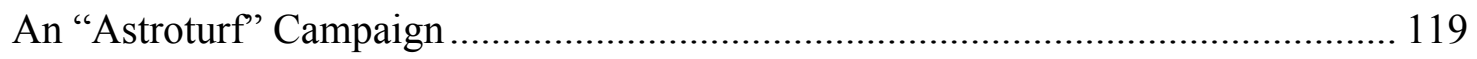

Creating a Wedge

What Would San Francisco Do? .......................................................................... 126

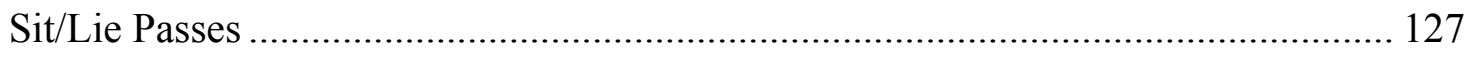

Chapter 7: Cross-Case Comparison and Implications for Theory and Practice ............ 128

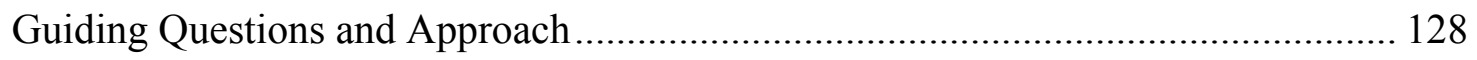

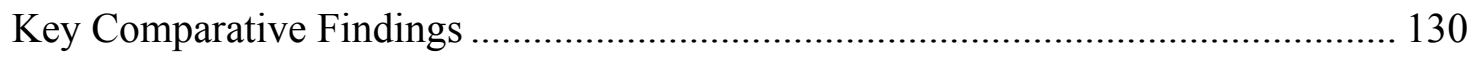

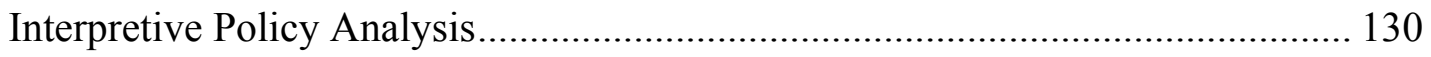

Neoliberal / Right-to-the-City Actors in the political economy .............................. 133 
Homelessness in Policy Discourse and Social Movement Framing ..................... 139

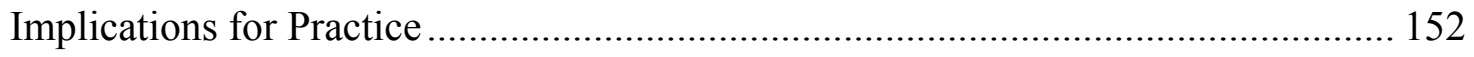

Framing and Use of Policy Discourse ......................................................... 153

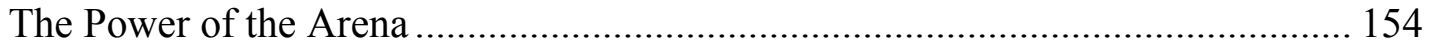

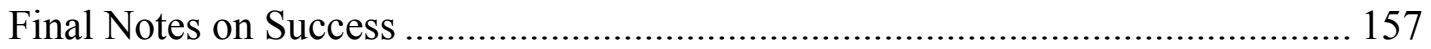

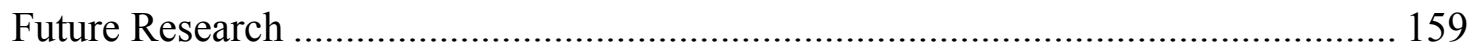

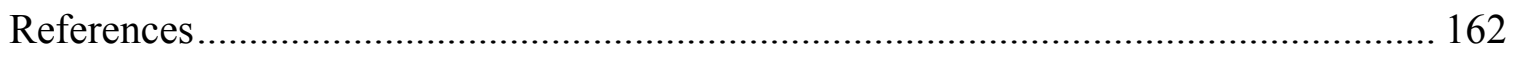




\section{List of Tables}

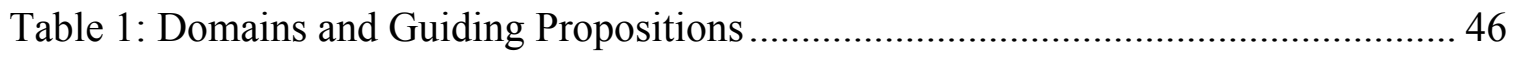

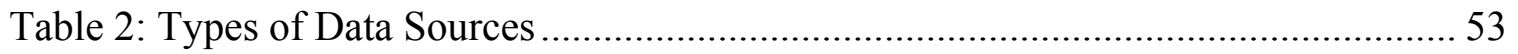

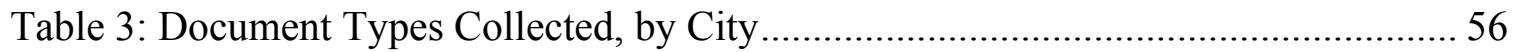

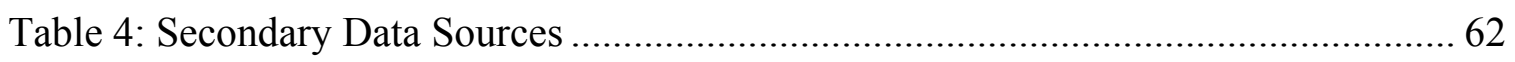

Table 5: Policy Arenas and Process Comparison ..................................................... 131

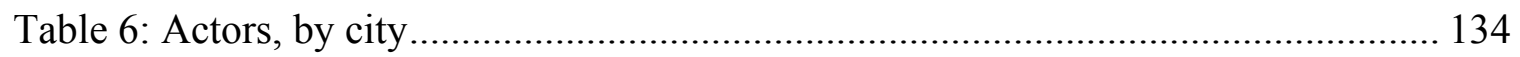

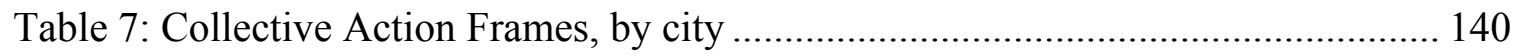

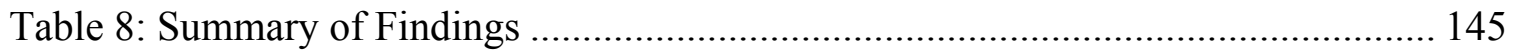




\section{List of Figures}

Figure 1: US Cities with regulations restricting sitting or lying on sidewalks. Data from

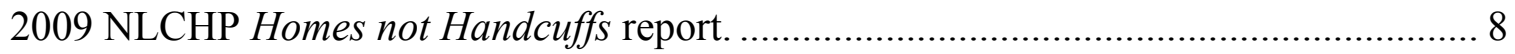

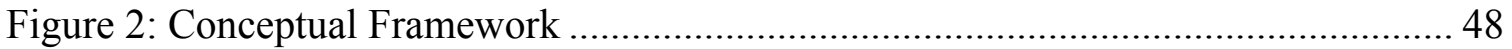

Figure 3: Theoretical Findings and Relationships ........................................... 148 


\section{Chapter 1: Introduction and Problem Statement}

In 2010, San Francisco voters were poised to vote on an ordinance prohibiting people from sitting or lying on sidewalks. In the months leading up to the election, San Francisco Chronicle columnist C.W. Nevius wrote regular articles in support of the law. In nearly every column, he made the argument that the dirty, diseased, deviant, dangerous mobs of people sitting on streets in neighborhoods like the Haight/Ashbury were a menace to society. "The whiff of urine in the street, the drunk on the sidewalk, and the aggressive panhandler are constant reminders that San Francisco can't seem to get a handle on the challenge of deadbeats who loiter on the city's sidewalks. If we forget, we're reminded by tourists who came to what they thought was a world-class city" (Nevius, 2010). In this last phrase, Nevius reminds us of the importance of managing the image of the city for supporting tourism in a "world-class city."

This argument references a specific image of how a world-class city must be made, seen, and experienced. Nevius' message to residents of the city is to take action and re-make the city to conform to this image of a global city. People opposed to the ban argued instead that the effects of such a ban placed undue hardship on those who are down and out and restricted their rights to public space. Similar debates rage in many cities in the United States.

Cities increasingly enact policies that restrict the visibly homeless from public spaces. At least 70 U.S. cities, including many of the "progressive" cities along the west coast, have some form of ordinance restricting sitting or lying on sidewalks in central city 
areas during business hours. While these ordinances technically apply to all people, supporters advocate for their use in order to displace those who appear to be homeless. This widespread strategy for controlling the use of public space by the very poor is just one in a suite of neoliberal policies that shape the geographies of public space in cities to serve the needs of global capital.

Neoliberal thought is based on the idea that the economy is best run by individuals working in their self-interest, organized through market forces. Neoliberal policies are a powerful influence on the shape of the city, including poor people's experience of it. This includes a shift of the role of the state, from buffering the negative effects for those harmed by market forces, to a focus on partnering with private capital (Smith, 2002). Further, neoliberalism sees the role of the state as facilitating global capital, rather than redistributing wealth. This is a complete shift in the role of government, and is both an economic and a political project (Purcell, 2002; Brenner \& Theodore, 2002). This project and the associated political and economic structures are the structures that provide the context in which local actors make policy.

Neoliberal forces change the social relations of space at the local level (MacLeod and Ward, 2002). The project of those who control capital has longed changed urban space through dispossessions of the visibly poor. From Haussmann's plan to reshape Paris into boulevards that would allow for easier control of the poor to Moses' plans for urban freeways in New York and across the United States that cleared out poor neighborhoods, to the removal of slums outside mega events, and now the criminalization 
of homeless people's use of public space, the neoliberal project has included a changing of the use of public space that has displaced the poor (Harvey 2008). The right to the city, or a fighting against this project for a right to use public space in a way that serves the everyday needs of the poor, continues.

The current neoliberal argument is that cities must have clean and safe downtown areas, which the presence of homeless bodies impedes. However, neoliberal forces are not all powerful, but rather there are various states of "actually existing neoliberalism" that are different across localities based on the historical local contexts of each place (Brenner \& Theodore, 2002). There is also resistance to these efforts that need to be further understood. For Harvey (2003), it is the right to make the city a place for everyday life that counters the effects of the neoliberal project's assault on public space. The right to the city is the need to resist the ways in which the ruling elite define how and for what purposes public space can be used. Sit/lie ordinances are examples of local decisions that serve the needs of global capital by making cities comfortable places for those working in global capital to live and visit, and to support gentrification (Smith, 2002; Mitchell, 2003).

Part of the local context is resistance to neoliberal forces, which is present to varying degrees and forms in cities. This resistance takes shape as people enact their rights to the city. In the example of sit/lie ordinances, there is a complex relationship between neoliberalism and rights of residents to use the city that occurs during the local policy-making process. Generally speaking, the stages of the policy process include 
formulating the agenda for policy, deciding what policy to use, implementing the policy, evaluating the policy, and if a decision is made to, then ending or terminating the policy (DeLeon, 1992; Sabatier, 1995). This study is a comparative case study to examine three stages of the sit/lie ordinance policy making process: when the ordinance comes into the policymaking agenda, when the policy decision is made, and when the policy is initially implemented.

While there are many factors that come together to create policy, this project focuses particularly on conflicting policy talk in the public sphere as represented in newspaper articles and during public meetings. These multiple and conflicting narratives in the public sphere shape the policy debates and show how actors respond to policy options and proposals. In policymaking we know that language is important because it both structures and reflects what we think. In a context of networked governance, when more than just lawmakers participate in the creation of policy, private actors can and do influence policy, and they do it through talk. Indeed, "language is an expressive act and a form of power, and language is a creative and controlling force that has identifiable effects" (Marston, 2004 p. 24).

The purpose of this research is to describe policy talk that shapes the agendasetting and policy-selection stages of the policy process around the creation of sit/lie ordinances. The primary research questions for this study are: Who are the actors and what policy talk do they use? How do these influence policy talk and decisions over time? 
The first research question is broken out into specific questions about the actors and policy talk as follows:

- Who are the institutional and individual actors advocating that policymaking agendas include sit/lie ordinances? What discursive strategies do they use to frame their positions? Who are the institutional and individual actors contesting these ordinances and what policy talk do they use to counter them?

The second research question can be broken out into the following questions about how these decisions influence policy talk and decisions over time:

- How do the tensions between different discursive strategies work to change the course of a policy process? How do actors use different arguments? How do actors use policy talk to respond to each other? Which are the most effective narratives at shaping the ordinances? How do local contexts shape both policy talk and policy outcomes?

To answer these research questions, I conducted a comparative case study of the actors and policy talk in public debates around the passage of sit/lie ordinances in Portland, Oregon and San Francisco. Case studies allow researchers to develop a further "understanding of what causes a phenomenon, linking causes and outcomes" (Flyvbjerg, 2011). This design allows us to see how the debates over sit/lie ordinances, and the local contexts in which those debates occur, shape policymaking in a neoliberal context. The 
study used data collected from three main types of sources: archival documents, interviews with key informants, and a review of secondary data.

Archival documents came from newspaper articles, written position papers/documents from advocacy groups, and minutes from public meetings. I conducted a formal content analysis of the newspaper of record in each city, with the assumption that this is the document that would most likely be read by the largest section of the policy- making public. News coverage from alternative weeklies was used to supplement the narrative creation and development of timelines, and identification of various actors. Review of the public meeting notes, documents, and minutes supplemented the description of the timelines and cases and actors. The news documents are one historical record of events, but news media often doesn't capture the participation of all the actors evenly.

Interviews with key informants helped with identifying excluded actors, the policy talk they use, and why. Interviews also helped to answer the "why" questions about why certain choices were made when. I also included secondary data to describe the local context of each case, including census information about changing demographics, academic research on the structure of the political and grassroots systems in each city, and data about the extent and geographical distribution of homelessness. I used all these sources to construct a case study for each city, and then to compare across both cases. 
The focus on language allows us to see how multiple and conflicting narratives in the public sphere shape the policy debates, and how certain language takes prominence over others (Marston, 2004). This focus on policy talk is "an acknowledgement that policy-making is a communicative event structured by a range of competing discourses, in which there are unequal outcomes for different policy participants" (Marston, p. 30). I used thematic coding (Braun \& Clarke, 2006) to identify how neoliberal forces and resisters communicatively shape policymaking through claims-making arguments of supporters and resisters. The results of this study add to the theory about resistance to neoliberalization and contribute an analysis of activism that informs grassroots practice.

This dissertation summarizes a review of the relevant scholarly literature, the conceptual framework and research methodology that guided this research, and then presents the findings in several parts. Chapter 4 is an overview of the social, political, and economic context structuring the conditions in each city, and a brief history of each of the cases. In chapters 5 and 6, I provide a narrative of findings from each of the cities in the study, focusing on the actors, strategies, and discursive strategies used during the policy process. Chapter 7 provides a comparison of findings across the two cities. The final chapter focuses on theoretical findings and implications for practice.

\section{Sit/Lie Ordinances and Need for Research}

This section summarizes the rise and use of laws restricting sitting and lying on sidewalks, and the academic research around them. Cities across the country have increasingly been using sit/lie laws to control homeless people, making it a national 
policy issue. Academics have also studied the regulation of homeless people's use of public space, but little research has been done on these specific laws or how they come to be passed and resisted.

\section{Rise of sit/lie ordinances to control homeless people}

In what is probably the most comprehensive cataloguing of occurrences of sit/lie ordinances in the United States, the National Law Center for Homelessness and Poverty found that in 2009 thirty percent of the 235 cities they surveyed have sit/lie ordinances (NLCHP, 2009, p. 10). These cities are highly concentrated along the more urbanized west and east coasts where high costs of living and housing set the backdrop for high numbers of visibly homeless people living in public spaces. With the increasing numbers of people living in poverty, the conflicts over public space are likely to grow.

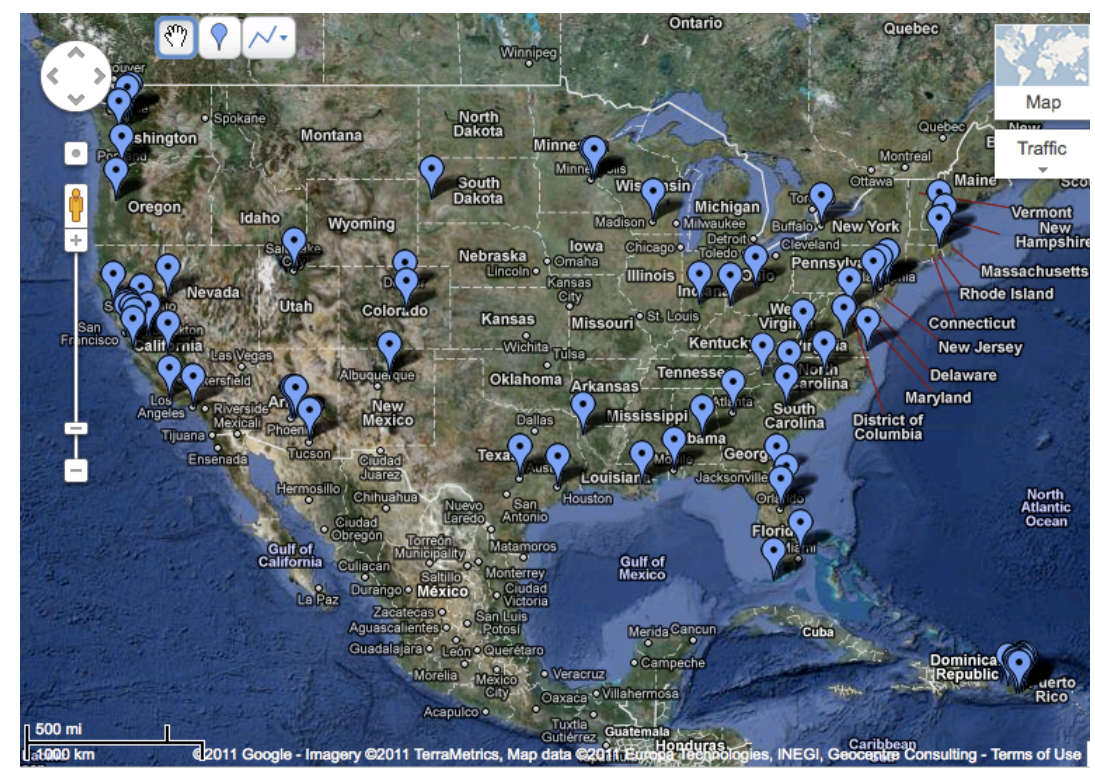

Figure 1: US Cities with regulations restricting sitting or lying on sidewalks. Data from 2009 NLCHP Homes not Handcuffs report, map created via Google Maps. 
These ongoing conversations in communities around the country constitute public debates about how people conceptualize and use public space. Who gets to use public space, and for what purposes? Which uses of public space should be prioritized when there are conflicting ideas of what is allowable in public? Which users and actions should public policies protect, and which should they regulate or punish? Those of us concerned with advancing the theory and practice of social justice find these important questions to ask because they help us understand the ways in which actors create, use, and appropriate public spaces.

Public spaces facilitate a variety of informal interactions between diverse groups of people who are strangers to one another. Early public spaces researchers described them as places for commerce, leisure, community building or politics (Lofland, 1998; Jacobs, 1961; Whyte, 1980). More recent research has focused on conflicts over public space, many including conflicts over homeless people's right to the city (Mitchell, 2003). As the number of people experiencing homelessness has increased, and the neoliberal agenda has made the displacement of these people a higher urban policy priority, the use of laws to exclude homeless people from public space have increased (Mitchell, 1997). We now have much larger populations that have no access to private or semi-private places.

Street dwellers have no access to private homes. Many semi-private spaces, such as malls and department stores also discourage use by the visibly poor. This leaves a whole class of people who are literally living their entire lives in public. For those 
without access to private places for sleeping, eating, and living, public spaces become the places of everyday life and survival. Sitting, sleeping, urinating, and eating are required for survival and these must be done in some place. The restrictions from doing these things in public, when the person has no access to a private place therefore essentially makes the activities necessary for basic survival illegal (Waldron, 1991, Cresswell, 1997).

The new neoliberal approaches to controlling homelessness, and the associated deviance are very different from the kinds of informal social control that Jacobs and Whyte first described in early public space research. While both acknowledged that homeless people pay an important role in public life, they advocated for a mixed group of public space users who could maintain the safety of all the users through "eyes on the street." At the time of their writing there was a much more limited amount of street homelessness. Now the conflicts over controlling deviance in public space are bigger problems, especially as incidences of mental, physical and behavioral health issues have also increased.

Rather than addressing the causes of street homelessness, cities now seek to control this particular perceived deviance through regulations rather than informal social control (Davis, 1992, Loukaitou-Sideris et al., 2005). Exclusions from particular spaces have been used as a formal social control of people through their use of space (Beckett \& Herbert, 2008). This new reality is a concern for many researchers who have documented the increasing privatization of public spaces. Researchers have documented 
the role of semi-public plazas created through public-private partnership, the increasing use of privatized malls as key community gathering spaces, and the revanchist policies that criminalize and regulate poor people's use of public spaces (Davis, 1992; Kohn, 2004; MacLeod \& Ward, 2002; Smith, 2002).

This "loss of public space" argument has been criticized for having an overly romanticized notion of what "public space" used to be. Indeed, public space in the United States has never been a place where everyone always is welcome, public spaces are places of contention over conflicting uses and users (Staeheli \& Mitchell, 2008). There have been many historically different uses of sidewalks in cities as places for commerce and everyday life, many uses being in conflict with each other. As places of contention, multiple users have different needs with sometimes incompatible functions.

Indeed, urban planners have been trying to reduce congestion on sidewalks for a long time, with a focus on unimpeded movement of people as a primary goal (Blomley, 2010; Ehrenfeucht \& Loukaitou-Sideris, 2007). Early regulations on sidewalks often focused on keeping shopkeepers wares from crowding out paths for pedestrian movement. Policing of public spaces such as sidewalks is also different than in private spaces. Police have more access to these spaces and thus can rely on their own experiences and observations rather than tracking down witnesses or re-constructing what happened during the commission of a crime, giving more power to police in observing, defining, and enforcing “crimes" (Stinchcombe 1963). 
In the contemporary city, conflicts on sidewalks are more likely to be about the differences between the rich and poor, than about shopkeepers storing their wares on the sidewalk. Thus, the formal social control has shifted to control of the homeless who face a variety of regulations about where they can sit, stand, eat, sleep, or panhandle. For people who are homeless, and have no private space to access, the things that they do are thus visible to police in a way that they aren't to those who have access to private space (Stinchcombe 1963).

Some of these activities of daily life such as sitting down, lying down, and drinking alcohol are legal if done in private, but not legal if done in public. This is especially problematic for someone without access to private space if the activities are necessary for survival like lying down to sleep. Local governments have multiple ways to regulate the use of sidewalks, but it is often done through placing time, place, and manner restrictions on certain behaviors. In the extreme case of Las Vegas, the city recently privatized sidewalks to allow for more regulations of those behaviors (Blumenberg \& Ehrenfeucht 2008).

Researchers have argued that the more recent rise of sit/lie ordinances is connected to "a larger shift in the very constitution of the public sphere: from the productive public sphere and its preoccupation with idleness to the consumptive public sphere and its preoccupation with aesthetic appearance" (Feldman 2003, cited in Loukaitou-Sideris \& Ehrenfeucht 2009 p. 165) While earlier laws limiting vagrancy (which was defined in part as not being willing to work if you are physically able) were 
supported by businesses worried about finding labor in a production based economy, in a consumption-based economy the concern from businesses is that certain people appearing in public will push away consumers (Loukaitou-Sideris \& Ehrenfeucht, 2009). This change in the political economy means that rather than making "vagrants" work, we are interested in controlling the appearance of the city by making some people disappear.

The current literature on sit/lie ordinances frames these policies as examples of local decisions that serve the needs of global capital by making cities comfortable places for those working in global capital to live and visit. The argument is that having dirty and unsafe downtown areas will keep businesses from locating in cities, thus pushing cities further into decline. The conventional wisdom of anti-globalization academics is that global capital and neoliberal forces make local governments support the needs of global capital (Brenner \& Theodore, 2002; Gibson, 2004; Hackworth, 2007; Hartman, 2002; Harvey, 2008; Smith, 2002; Wacquant, 2001)

\section{Need for research and theoretical contribution}

Previous research on globalization and local politics tells us a lot about the actors

of global capital; we know that at the local level members of the growth machine work to support the goals of the transnational corporations and international financial institutions at the global level (MacLeod \& Ward, 2002). This is the implicit story of critics of neoliberalization, that the growth machine pressures local governments to make changes that benefit business over the needs of residents. 
Research substantiates that neoliberalism has been the force behind the increasing penalization of the poor as a strategy to control social insecurity (Wacquant, 2001; 2012). However, this view has been criticized for having an incomplete analysis of resistance (Piven, 2010; Mayer, 2010). Indeed, we have to work harder to imagine how local actors can resist these powerful players. The research literature is just starting to peel open the lid of that black box of understanding of how actors resist neoliberal forces and begin to claim their rights to the city.

While the right- to- the- city framework is a promising call to action for social justice and explanatory theory for resistance, having a right to the city in and of itself doesn't necessarily create a more socially just society. We need more empirically based examples of who gets rights to what city, and how those rights might be fought for and won. For example, some may argue that neoliberal forces already have a right to the city. Those who are able to access powerful decision makers and can convince them to make policies on their behalf and, benefit from cultural and social norms that legitimate and prioritize their existence. These actors already exercise their rights to participate in making the city, but this is not what Lefebvre meant when he called the masses to action in the city streets. So, how do other actors fight to make that right to the city available to the very poor?

These policies have ramifications in daily life for those who are most impacted by them, and they are also key elements in the political, social, and cultural conflicts over the right to the city. This multiple case study describes the events and interactions that 
shape the agenda setting and policy selection portion of the policy process around the creation of sit/lie ordnances. The findings will contribute to theories of the right to the city and local resistance to neoliberalization by elucidating the work of different actors in influencing local policymaking. To do this I ask: how do different actors, situated in specific local and global contexts, influence the adoption of sit/lie ordinances? 
Chapter 2: Literature Review and Conceptual Framework

This dissertation draws from multiple scholarly disciplines to describe and interpret the cases of interest for this study. This approach relies on three main bodies of literature: (a) Neoliberalism and right-to-the-city theory, (b) the framing literature from social movements theory, and (c) interpretive policy analysis and the role of discourse in the policy process. Each of these areas of research informs the issue of sit/lie ordinances. First, the research helps to frame the tensions in contemporary urban policy between the rise of a neoliberal policy environment on one hand, and the right-to-the-city movements on the other. Then, the social movements field of sociology and the interpretive policy tradition both focus on the role of discourse and narrative in structuring social action.

\section{Literature Review}

This examination of the literature revolves around several critical elements pulled from the relevant literatures: the actors, the political economic context, and the language or discourse. The following sections take a deeper look at the bodies of research from these perspectives.

\section{The Neoliberal City and the Right to the City: The Actors}

Neoliberal thought is based on the idea that the economy is best run by individuals working in their self-interest, organized through market forces. Neoliberal policies are a powerful influence on the shape of the city, including poor people's experience of it. This includes a shift of the role of the state, from buffering the negative 
effects for those harmed by market forces, to a focus on partnering with private capital (Smith, 2002). Further, neoliberalism sees the role of the state as facilitating global capital, rather than redistributing wealth. This is a complete shift in the role of government, and is both an economic and a political project (Purcell, 2002; Brenner \& Theodore, 2002).

There have been at least two phases of the neoliberal project, called roll-back and roll-out neoliberalism (Brenner \& Theodore, 2002). The first, or roll-back phase, is usually associated with the Reagan and Thatcher administrations' focus on policies which "rolled-back" the social safety nets and programs for the poor. This was done by local, state, and national governments, but also on a global scale through World Bank/IMF austerity measures and structural adjustment regimens. The second phase, roll-out neoliberalism, is the rolling out of new policies that restructure the state to support the needs of global capital, such as policies that support gentrification and displacement of the poor. These policies are also constructed on a variety of scales. This study focuses on how roll-out neoliberalism is constructed on the local level.

\section{Roll-out neoliberalism and homelessness policy}

Roll-out neoliberalism forces change the social relations of space at the local level, including how homeless people experience the city. Smith argues that neoliberal forces have done this largely by dispersing "unwanted" people from certain urban geographies as a tactic for "making the city safe for gentrification" (Smith, 2002, p. 442). Gentrification, supported by policies of the state and actions of business and developers, 
has influenced the distribution of poverty across cities. Following the disinvestment of cities in the first eras of de-industrialization and suburbanization of white and middle class black families, in many cities the central neighborhoods were largely pockets of concentrated poverty. As the "gentry" began coming back to these disinvested neighborhoods, the effect of the housing prices and cultural changes related to gentrification has been to push poor people out of the neighborhoods that they had lived in for so long.

In addition to gentrification, criminalization policies, such as the "tough on crime" zero-tolerance policies in Giuliani-era New York City, and subsequently adopted across the country, have moved poor people out of public spaces. These policies pushed poor people out of certain neighborhoods. The policies, including "broken windows policing," criminalized poor people's existence in public as their physical existence in run-down neighborhoods were seen as just more indicators of neglect that could increase crime. Despite the continual evidence contradicting broken-windows-policing theory, these policies have spread beyond New York City across the United States and even internationally (Beckett \& Herbert, 2008; Herbert, 2001; Herbert \& Brown, 2006). These zero-tolerance policies for dealing with crime and the control of deviance is part of the "revanchist" neoliberal city, or the turn of the state to supporting the needs of capital after a period of a more distributive policy that was intended to help poor people (Smith, 1996). 
Policies that push people out of space have also been described as elements of downtown redevelopment plans (Gibson, 2004; Hackworth, 2007). For example, Gibson (2004) has described how Seattle in the mid-1990s the city was trying to develop a "world city" reputation, and undertook a large number of cultural projects in the downtown core. These projects, including a project for a new home for the symphony, and support for keeping the Nordstrom department store in downtown, resulted in Seattle also attempting to move some services for the homeless away from the same area. In San Francisco, redevelopment of the south of the market area to build a museum and Yerba Buena shopping and park area also displaced the very poor through the demolition of many SRO housing buildings (Hartman, 2002). However, in the two cases of sit/lie ordinances in the mid 2000s of interest in this study, there don't appear to be specific development plans that are precipitating sit/lie ordinances.

Neoliberalism reduces democracy at the local level as cities chase capital from international firms and investors, rather than national capital or government funds (Purcell, 2002), putting the power over local decision-making in the hands of global actors. However, neoliberal ideas themselves don't change the social relations of space. Neoliberalism is a set of ideas and assumptions about the role of the market in distributing social goods, not an actor that makes decisions. Rather, people embedded in social and institutional systems take certain actions that work toward goals that support the globalization of capital. 
It is these actions that have actual impacts on the local level. This process, the interplay between global forces and local actors, has been described as glocalization. This term, a coupling of global and local, describes a recognition that a diversity of societies and cultures at the local level continue to have different trajectories, even when they all experience similar globalized forces. In other words, the global forces affect all places, but because of the variety already existing, have different outcomes at each place that are neither explicitly global nor local, but a blend (Brenner \& Theodore, 2002; Swyngedouw, 1997). Thus, understanding these local processes can provide insight into how the actors and local contexts work to create differences between locations.

Neoliberalism is causing sit/lie ordinances to be used more often, which is further marginalizing homeless people. Neoliberalism is not only an economic project, but also a political project set on changing the role of the state to support market-based decisionmaking (Wacquant, 2012). Recognizing the local politics component of neoliberal policies has important implications for social justice actors trying to stop sit/lie ordinances. Small scale local actions may not be very effective against global scale economics, but have the potential to influence local political decision making. A first step to the theory and practice of resistance to neoliberalism is to further understand the specific localities of that political project, and the currents of existing resistance.

The existing literature on sit/lie ordinances theorizes that they are part of a neoliberal agenda for changing cities. While this might be mostly right, we need to look more closely at who the actors are in that neoliberal agenda, and the messages they use to 
advance their perspective. According to the theory, there are at least two categories of actors working in the service of roll-out neoliberalism to further sit/lie ordinances. The first category includes local decision-makers who want to keep business happy in order to keep their jobs and tax revenue in the city. The second category is business interests that need the livability laws in order to keep their employees happy and support increasing property values (since the real estate market is such a global economic driver). While these motivations are likely to be important, we need to know more about the motivations behind these interests in supporting sit/lie ordinances. This research seeks to uncover those motivations through interviews, as well as through the messages used to argue for the ordinances.

However, it is an incomplete picture to only look at neoliberal actors. While powerful, these actors are not the only ones influencing decision-making. There are other groups of people, who I am calling the right-to-the-city actors, who come together to fight for a vision of the city that supports people who live there, not necessarily the global business or exchange value needs of the city. There are formal Right to the City organizations that are part of this group, but for this research this category also includes the other organizations and actors that have participated to try to stop sit/lie ordinances including human and civil rights organizations, homeless service providers and advocates, and other progressive mission-driven groups. They aren't necessarily working together with each other and may use different messages and strategies, but are similar in their opposition to sit/lie. 


\section{The Right to the City Actors}

While neoliberalism is a driver of sit/lie ordinances, there is also resistance, which is conceptualized in the literature on "the right to the city." The literature on rights to the city is where we find an analysis of the types of resistance to policies that penalize the urban poor. The right to the city can be thought of as both the right to use public spaces of the city, and to participate in the making of the city (Lefebvre, 1996; Purcell, 2002; Harvey, 2008; Sorenson \& Sagaris, 2010). Harvey (2008) calls this right a fundamental human right. These are rights to particular spaces that are shared by many, making this a collective right, rather than an individual one (Sorensen \& Sagaris 2010). People exercise this right to places on the very local scale, through inhabiting spaces and participating in community institutions and decision-making.

In this way, Purcell (2002) argues that the value in the right-to-the-city approach is an "urban politics of the inhabitant (p.100)." Denizens of cities should have the right to participate in the making of the urban space that they inhabit (Purcell, 2002; Lefebvre, 1996). This extends the liberal notion of democracy in two ways. First, it expands who is eligible to participate from those who have citizenship in a particular nation state to include all those who inhabit the space. This would be more inclusive of a variety of politically and economically marginalized groups, including the homeless. The problem though comes in defining the range of denizens in a city. Is the CEO of Nike considered a denizen of anyplace she travels for business? How long must one inhabit the city before becoming a denizen? Must you own property to be a denizen? How do the homeless fit? 
The second way in which the right- to -the- city approach expands the notion of democracy is through calling for participation in the decision-making outside of the state. Given that so many actions by international corporations and financial institutions can reshape urban spaces, a right to the city would require a central role in participating in those decision-making processes as well (Purcell, 2002). Many activists do indeed seek to change the decision-making of global capital actors through protest, boycott, and shareholder activism. With the possible exception of shareholder activism, one can hardly argue that the right to protest is the same as the right to participate in corporate decision-making. For those experiencing homelessness, the ability to participate in decision-making in the city is even more complicated.

It is difficult for people experiencing homelessness to participate in making the city, especially since homelessness often corresponds with social marginalization and feeling ostracized and outside of society. It is also difficult to participate in representative democracy when a person lacks an address for voting, and when instead one must focus on getting basic needs met, rather than participating in public meetings or advocacy efforts. But despite these challenges, homeless people and their allies do organize (Corrigall-Brown, Snow, Smith, \& Quist, 2009; Cress \& Snow, 2000; Mitchell, 2003; Piven \& Cloward, 1977; Wright, 1997). However, they also face retribution from the police and in some cases have been excluded from shelters due to their political involvement in protests (Williams, 2005). While much research on homeless organizing focuses on welfare rights and rights to housing, there is less known about actions about rights to public space. The right-to-the-city theory suggests that those living in public spaces in cities should have a right to do so, and to participate in the making of their city. 
There is strong interest in the potential of a rights-based framework for social justice for the poor, but less literature on how these activities work. Scholars ask key theoretical questions about who should have which types of rights, but less empirical work has been done on how activists' work is currently shaping the fight for those rights to public space. For example, in Harvey's 2008 article on the right to the city, the two brief examples of resistance are the 1871 Paris revolts and the late 1960s urban revolts in the United States following the assassination of Martin Luther King, Jr. We need more in-depth, contemporary examples of resistance activities that might fit the right-to-thecity framework.

One important exception to the lack of empirical examples is the work of Sorensen and Sagaris (2010) who found that the right-to-the-city works through collective actions at the neighborhood scale. They find that successful cases of neighborhood-based collective action in local urban governance were successful because they had an infrastructure of long-term, multi-issue community-based organizations that were able to create alternative participation structures to influence decision-making outside of official planning processes. In doing so, they make claims about their right to the city "by demanding a voice in decision-making that affects their neighborhood" (Sorensen \& Sagaris 2010, p. 312).

These demands provoke conflict, but are actually signs of a useful democratic process. Staeheli (2010) argues that disorder, rather than just being something that must be accepted in a democracy, is important to maintaining a democracy. She argues that 
since democracy isn't so much a state of being, but rather an ongoing process, the antagonisms over public space allow for ongoing debates and decisions about how to make policy decisions.

\section{Actors location in the global economy}

The actors, both neoliberal and right-to-the-city, vary across different locations. While there are overarching global and national forces that set the stage for similar policies across cities, there are local differences. Cities have different positions in the global political economy that may change both the actors and the arenas for action, which would influence the messages used. Both Portland and San Francisco have local, regional, and transnational elites, but in different proportions. In some cities the global or local economic actors may be more prevalent or influential than in others.

For example, San Francisco has a large concentration of technology, venture capital, and global financial services firms in the downtown area. Their interest is in maximizing the profits from their investments and supporting their economic needs. This may lead to their position that cities should enact roll-out neoliberal policies (such as sit/lie ordinances) to protect their investments and economic needs. It was been assumed in much of the neoliberalism literature that this global reach of capital may also change the arenas of action as distant corporate landowners may need to act through business associations or other intermediaries. However, this was not found to be the case in this policy. Instead, it was individuals, who were heads of global corporations and investment companies, that supported the passage of the law rather than the corporations 
or investment companies themselves. It was actually the Portland businesses that worked more through an intermediary trade organization, while the San Francisco elites had direct connections to local decision-makers.

While the Portland region is also home to several transnational corporations, the property and business interests in the areas targeted in the sit/lie ordinance are more locally owned. Commonly held logic is that local business and property owners may be more likely to have personal relationships with other local elites in politics than distant investors. However, in Portland these business interests were largely represented on this issue through the powerful business association.

In a similar way that the neoliberal actors are different depending on the particular city, the right-to-the-city actors also vary across cities. Due to previous organizing histories in Portland and San Francisco, for example, there are different organizations, each with their own strengths, weaknesses, strategies, and resources. These differences are important to the messages used in sit/lie campaigns and contribute to the other variations in outcomes.

These variations in types of actors are important because they suggest different strategies for influencing decision-making. This research explores who those actors are, and how their characteristics and location in the local economy impact the political strategies that they use. Understanding the city's actors' location in the global economy matters because theory says that global neoliberal actors will want local decision-makers to support policies that allow for the roll-out of global capital. Research has documented 
this effect especially in the support of policies that increase gentrification and the associated increases in land values in central urban areas (Smith 1998). While researchers have presented less evidence of involvement by global economic actors, researchers have claimed that sit/lie and other "livability" ordinances have been instigated by local decision makers on the behalf of these actors. This research helps explain how those hypothesized connections between neoliberal actors and local decision makers function. These positions in the global economy are what Yin might call contextual elements of the case study (Yin 2003). Contextual elements are important elements to understanding the immediate topics in question. In this research, the immediate topics are the messages used to influence decision making.

In order to explain how these connections work, I will be comparing across cases with different locations in the global economy. In order to do this, I compare the strategies and messages used by global, national, and local elites. The differences can help us explain variation in messages and outcomes surrounding sit/lie ordinances in particular, and in the ways neoliberal actors influence local decision making in general. In addition to supporting theoretical refinement, these findings can help grassroots actors analyze and strategize about their local conditions.

\section{Social Movements: Political process, resources, framing, and motivation}

The actors' location in the global economy and right- to- the -city landscape influence the strategies, messages, and other actions that they take. Social movement theory can help us understand more clearly how these differences in neoliberal and right 
-to- the -city actors impact the discursive and policy outcomes. While we may debate whether the actors important to this study fit any of the multiple definitions of a social movement, the literature is relevant because it is concerned with understanding the collective actions that people take in order to influence social issues. The social movement literature tells us that there are at least three main points that are important to understanding collective actions: opportunities in the political process, resources for mobilizing, and framing of messages.

The first point is that social movements must find windows for action, or political opportunities (McAdam, 1996; Tarrow, 1994). Scholarship in this area confirms that these actors are part of a political process through which decisions are made, and they rely on these windows of opportunity throughout the process. Second, the actors need to have human, social, and economic resources available to organize participants and influence decision-makers (McCarthy \& Zald, 2006). Third, collective action needs to use the appropriate frames in order to convince others to join their cause and take the requested actions (Cress \& Snow, 2000).

While there is much debate in the social movements literature about which of these theories best explains social movement formation, behavior, and outcomes, researchers have begun to see the value of looking at the interactions between the different theories. Researchers have called to examine the interconnections between these different areas to understand how structure and agency both influence social change (Meyer, 2002). Empirical research has found that framing is most effective when it fits 
within the political opportunity structures (McVeigh, Myers, \& David, 2004). Others have found that the actors in social movements shape and change frames as movements develop and tactics change (Holland, 2009; Ryan \& Gamson, 2006).

I continue in this tradition by using insights from all three to form the conceptual framework that explains how and why sit lie ordinances have come to pass. In this way, I am combining the more structural elements (political process, available resources) with the explanations of how agents work (though frames and based on their motivations). The structural elements vary based on the local contexts. These local variations provide opportunities and constraints to actions that people take. In order to understand how messages change the policy process, we must also understand the context in which they occur. As a case study design, this research is able to look at how these structural and agential elements come together to influence each other, giving us a more full picture of how policy making around sit/lie ordinances occurs.

The term mobilizing structures refers to the organizations and connections to others that people create in order to engage in collective action (Tarrow, 1994). They may be formal or informal. Organizations will use messages that have to do with their mission. For example, we can expect business organizations to use messages about supporting the businesses that they represent, while civil rights organizations can be expected to use messages about rights and justice. There are variations in these actors and organizations (mobilizing structures) across cities, which is a product of different local 
histories and a part of specific local contexts. These differences are likely to influence the messages used due to the missions and goals of the organizations.

The frames that social movement organizations use are consistent with their "organizations core norms, values and beliefs," and with the political and social environments in which they are situated (Reese \& Newcombe, 2003). Thus, research comparing across welfare and poverty organizations found that even with similar goals for alleviating poverty, different organizations use their own framing strategies to influence social change based on the surrounding political context and their organizational ideologies. For example, feminist organizations framed their struggle as one for mother's rights, while welfare organizations framed it as one for income rights (Reese \& Newcombe, 2003). I expect to find similar differences in my case studies.

Political opportunities exist when people perceive there may be some political change or momentum that can be exploited to push for social change (McAdam, 1996; Tarrow, 1994). This could be a key event (such as a violent crime), a change of elected officials, or something else that brings an issue to a political salience. A key event is likely to structure the messages that begin the debates. For example, if there is a particularly violent crime that is associated with a homeless person, advocates for a sit /lie ordinance may use that opportunity to frame the need for the ordinance as one of public safety. The way the debate is begun provides an important initial direction that can set the political agenda, but subsequent events or messages can change those 
directions over time. This research identifies key events that happen over the course of the time period in question and look to see how those events change messages.

Framing is a way to build collective identities and motivations. The literature has found some typical types of framings including those describing a perceived injustice and creating a group of adversaries that are responsible for the injustices (King 2008). Bedford and Snow (2000) also identify frames that identify what the nature of the problem is (diagnostic frames), what should be done about it (prognostic frames), and who should be held responsible. It will be important to look at how messages are forming adversaries, which tells us more about who the actors are and how they convince others to "be on their side." We also know from the literature that how targets of the ordinance (the homeless, in this case) are framed also influences policy decisions.

Researchers have studied how framing works in policy debates. For example, in his study of the homeless policy field in San Francisco, Noy (2009) found three dominant frames used to describe the causes of homelessness: individual choices, unemployment or low wages, systematic inequality. The actors on the political left and center shared framing messages about unemployment and systematic inequality, while actors on the political right used individual choice frames to describe the causes of homelessness. Even though actors on the left and center used shared diagnostic frames, they had different prognostic frames, disagreeing about how to solve the problem, largely because of disagreements about how to best use material resources. 
Organizations may use a wide variety of diagnostic frames in order to appeal to a larger group of potential supporters but focus attention on one prognostic frame. One successful social movement organization protesting economic globalization in Norway used a wide range of diagnostic frames, including domestic labor issues and inequality in the global south, but focused attention for action on taxing banks to help solve economic inequality (Sandburg 2006).

Other researchers have examined how the targets of the policy, in this case the homeless, are framed. Unsurprisingly, much of the research on framing of the homeless has found that in both research and public narratives homelessness is most often portrayed as the result of an individual deficit rather than a structural problem. Some of the research focuses on metaphors of homelessness. In a policy debate that seeks to regulate the behavior of homeless people, it is important to understand these metaphors because they contribute to the characterizations of "the homeless" and how they should act (Fopp 2009). For example, in analyzing metaphors used in academic research on homelessness, one metaphor that is frequently used is that homeless people "fall into a safety net," which suggests that someone's own mistake made them drop from the metaphorical tightrope and into the safety net, rather than, say, being pushed by the system. Rather than being neutral descriptions of the problem, policy language such as this sets up a mental frame that underlies the diagnosis of the problem and provided solutions. If someone "falls" into the safety net they should be helped by remedying their 
individual deficiencies, on the other hand, if they are "pushed" through structural situations, there are solutions for changing those pushing forces.

One study found that people experiencing homelessness are usually portrayed in newspaper accounts either as a separate "other" by using many us/them, we/they constructions, as victims, or as undeserving criminals (Widdowfield 2001). Another study found that while there is some variation across newspapers, the main characterizations were that homeless people should be helped if they will comply with social regulations (Schneider, Chamberlain, Hodgetts 2010). These constructions are used to reinforce certain ideas about who homeless people are, and what caused the situation they are in (Widdowfield 2001).

In his studies looking at messages around policies that restrict homeless people's use of public space, Bloomly (2010a, 2010b) has found that planners and engineers often uses the language of "pedestrianism" that argue that sidewalks are places for transit and movement of people, thus turning people who aren't moving into mere obstructions of flow similar to other objects like newspaper boxes or sidewalk signs. In addition to "othering" the homeless, this framing also serves to make all people who block pedestrian movement equal, discursively obscuring the class-based motivations for regulating the poor. Bloomly argues that this framing allows the debate to be about proper regulation of all obstructions to pedestrian movement, rather than about rights or harms to people. 
While not specifically about homelessness, work in the adjacent field of housing policy has found that policymakers used a discourse of "bad tenants" who make bad neighbors and need to be removed from public housing Marston (2004). Since most people don't want to be disturbed by neighbors doing dangerous things, this framing is hard to counter. It also focuses on individual actions, rather than a larger system of housing provision that has challenges to be addressed. This sets up a debate about public housing that focuses on tenant deficiencies rather than system deficiencies that is hard for resisters to change.

Other research shows how policy talk changes over time. Jacobs and Manzi (1996) examined how homelessness in Britain in the 1960s was portrayed in the media as a social problem that the state was responsible for helping to solve. Those narratives changed in the 1990s when relying on help from the state was reframed as dependency and self-help strategies were advocated for in policy documents. There were large political shifts in Britain (and also in the United States) between the 1960s and 1990s. These linguistic shifts both mark and reinforce of these changes. We can study the policy talk in policy documents to observe these changes, and also to see how these documents inform further reification or resistance to these changes.

\section{The role of discourse in the policy process and interpretive policy analysis}

This study focuses heavily on the public discourse that has shaped the political policy making process. Research on discourse can help us understand the role of ideology and framing of social problems that underlie the conflicting narratives in the public 
sphere over policy debates. As Marston writes, a text "can be investigated for how it actively constructs the social world and its subjects and how certain discourses gain dominance over others" (2004, p. 5). In general terms, the discourses Marston identifies are occurrences of speech, writing, and images that express ideas. In more specific social theory usage, following the writings of Foucault, discourse is recognized as the speech, writing, and images that express social relations of power (Fairclough, 2006; Marris \& Thornham, 2006; Parker, 2004). Discourses are both expressions of, and contributors to, socially constructed meaning. This social meaning is what Stuart Hall might call ideology. Hall says we "speak through the ideologies which are active in our society and which provide us with the means of making sense of social relations and our place in them" (Hall, 2006 p.272).

In-depth exploration of policy discourses, or the "interactions of individuals, interest groups, social movements, and institutions through which problematic situations are converted to policy problems, agendas are set, decisions are made, and actions are taken" (Rein \& Schon, 1993, p. 145) can help us understand how cities become the ways they are. This falls in the tradition of interpretive policy analysis, which draws attention to the social construction of decision making. This model sees policy making as, "a communicative event structured by a range of competing discourses, in which there are unequal outcomes for different policy participants." (Marston, 2004, p. 30) This approach to policy analysis recognizes that policy making is done within political processes, not through a "rational" model that obscures the decision making by particular 
actors (Fischer, 2003; Fischer \& Forester, 1993; Hajer \& Wagenaar, 2003; Innes \& Booher, 2003; Stone, 2001; Torgenson, 2003). Understanding the discourses used gives us a window into the power used during the policy process, and "the methodological assumption that informs discourse-based approaches is that politics is an arena in which different interest groups seek to establish a particular narrative or version of events as a means to pursue political objectives" (Jacobs, 2006, p.39).

\section{Conceptual Framework}

Based on the existing research from these three disciplines, I developed a conceptual framework for understanding sit lie ordinances and answering my specific research questions. This section makes connections between the different bodies of literature and describes how the concepts and theories in each are related and believed to interact in practice for this particular policy problem. I first cover how framing is used as a policy tool to move from discourses to decisions. Next, I review the literature on policy talk specific to homelessness and homelessness policy. Finally, I review what little research has already been done specifically on sit-lie ordinances and the need for additional research.

\section{Framing: From discourses to decisions}

Multiple actors and institutions deliberate policy decisions. These communicative actions take place through discourse in the public sphere (Habermas, 2006 [1989]). The public sphere is "a domain of our social life in which such a thing as 
public opinion can be formed" (Habermas, 2006 [1989], p. 92). These discourses in the public sphere are as Hall says, the "sites of a distinct type of social struggle" (Hall, 2006, p.272). Newspapers in particular are important venues that shape discourse in the public sphere. What they choose to cover, and how they choose to cover it varies. Local newspapers are influential on what larger publics think about issues, and they play a significant role in the setting of political agendas (McCombs \& Shaw, 2009; Oliver \& Meyer, 1999).

These discourses of homelessness are carefully crafted messages by groups. The social movement literature on collective action frames tell us that actors use discourse to convince people to become new adherents, to change their ideas, or change their behaviors. The way they do this is through the framing process by which they create collective action frames. Framing is the process by which social movement actors describe what is going on in order to convince others to support change (Cress \& Snow, 2000; Snow et al, 2004). The outcome of the framing process is a collective action frame through which the change will be pursued.

Part of motivational framing involves "constructing" or representing the targets, or people who will be affected by the policy. This positive or negative social construction of the target then influences the content of the policy. One typology of characterizations of targets describes the advantaged, contenders, dependents, and deviants as potential targets of policy (Ingram \& Schneider, 1993; Ingram, Schneider et 
al., 2007). This provides us one perspective and way of understanding the processes through which discourses affect policy decisions.

These literatures are broadly applied in their disciplinary contexts to the study of a variety of social questions. This research project, focuses on how a specific social question such as homelessness, influences the debates about policy. The next sections examine arenas where there is discourse on the social question of homelessness policing and policy.

\section{Discourses on the social question of homelessness}

This section reviews the literature on general approaches to policing homelessness and other homelessness policy. It helps provide the context for the policy-making happening in the cities and larger nation during the time of this study. It also discusses some of the existing research on policy talk around homelessness.

\section{Approaches to policing homelessness}

Approaches to homelessness vary across the country, with different jurisdictions choosing different policy solutions. The National Law Center for Homelessness routinely creates lists of the "meanest" cities in the United States for homelessness. Mean-ness is generally associated with strategies that criminalize homelessness and making living on the streets more difficult. The history of dealing with homelessness, and their general "mean" or "nice" approaches may help explain the variation in messages across cities in the United States for several reasons. 
First, the "mean-ness" may be a reflection of the type of policing that has existed in the city. Sit/lie ordinances are laws that need to fit into the type of policing that exists in a city or need to challenge the current type of policing. For example, such an ordinance may be counter to the philosophies of community policing or fit in well with zero tolerance or "broken windows" policing. I expect these different approaches, especially in respect to homeless issues, change how actors related to the justice system (police and related bureaucrats as well as civil rights advocacy organizations) act.

Second, the different actors may have different relationships with each other that would influence how confrontational (or not) their messaging and actions might be. For example, in "nicer" cities like Portland, the homeless service providers and advocates may have closer working relationships with police on a number of homeless issues, which the advocates might not want to jeopardize their status by being confrontational with police. Alternatively, in a city like San Francisco where the police and community organizations are already confrontational, debates about sit/lie ordinances may be part of a larger struggle, which also informs the discourse.

\section{Homelessness policy talk}

Consistent with what we might expect given the research on the underclass and undeserving poor, researchers argue that the homeless are usually constructed as dependents or deviants. Dependents are less powerful groups that are socially constructed to need protection by a policy. This group includes children, people with disabilities, and some of the "deserving” poor (Ingram \& Schneider 1993; Ingram, Schneider et al., 2007). 
This group often benefits from public policy, but due to their construction as dependents are often highly regulated through policy. The deviant group is often targeted for punishment because their actions are viewed as out of line with what is acceptable behavior. The visibly homeless on the streets are often in this group.

In addition to the individuals being constructed through metaphors such as dirty, diseased, and deviant, the discourses of pathology are often used to describe the physical areas that are inhabited by people experiencing homelessness (Mathews, 2010). These "bad" places or communities are blamed for the very problems the people in them are experiencing. This spatializes the policy response. If skid row is the cause of the "pathological" behavior, it can be argued discursively that a spatial solution is necessary. This often leads to redevelopment strategies that are aimed at improving the places and subsequently pushes the offending people out. Those supporting revitalization (and gentrification) of neighborhoods often use the metaphor of "the new frontier" to support policies that support new development into wild places (Smith, 1996). This metaphor relies on the assumption that the places that have experienced decline are "wild" or uncontrollable in their own right.

The use of metaphors of homeless as dirty, diseased, and deviant are connected to mainstream ideas of "citizenship and productivity" (Del Casino \& Jacoy, 2008, p. 192). Those who aren't rooted as a citizen of a particular place, and who don't work for wages, are suspect. Their very existence in public is constructed as outside of what is expected, they are "out of place" (Cresswell, 1997). 
Much of the discursive work about 'the poor' and 'the homeless' happens through othering (Katz, [1989] 2013). By creating an 'us and them' mentality, we are psychologically able to distance the deserving from the undeserving. This helps us psychologically to deal with the inhumanity of seeing bodies in such disrepair, and also keeps us from being responsible for it. It is "their" fault, and they have a certain culture or characteristics that keep them apart from "us" (Wright, 1997).

These specialized discourses around homelessness and poverty are important to the discussion of sit/lie ordinances, though public space research rarely directly acknowledges this. My research integrates public space theory with the how we talk about the visibly poor; integrating a better understanding of how the discourses of homelessness are influencing policies over public space. 


\section{Chapter 3: Research Design and Methods}

This chapter provides an overview of the research design for the study. First it covers the in depth research questions addressed. Then, it presents a summary of the conceptual framework linking the theoretical underpinnings of the study to the research questions and approach. Finally, this chapter provides details on the methodological choices, data collection, and analysis procedures used for this study.

\section{Research Design}

\section{Overview}

This case study research describes discourses that shape the agenda setting and policy selection involved in the creation of sit/lie ordnances. The policy stages framework identifies steps taken during policymaking. While the stages are not entirely linear and may not capture all aspects of policymaking, the stages of policymaking include: formulating the policy, deciding what policy to use, implementing the policy, evaluating the policy, and ending or terminating the policy (deLeon, 1992; Sabatier, 1995). For this study, I am interested in the stages in which the sit/lie ordinance comes into the policy-making agenda, when the decisions are made about which policy to use, and the initial phases of implementation.

While there are many factors that come together to create policy, this project focuses particularly on conflicting discourses in the public sphere as represented in newspaper articles and during public meetings. These multiple and conflicting discourses 
in the public sphere shape the policy debates (Marston, 2004). The results will add to the theory about local resistance to neo-liberalization and contribute an analysis of activism that will inform grassroots practice.

\section{Research Questions}

The primary research questions for this study are: Who are the actors and what discourses do they use? How do these influence policy talk and decisions over time? The first research question is broken out into specific questions about the actors and the discourses as follows:

- Who are the institutional and individual actors advocating that policymaking agendas include sit/lie ordinances? What discursive strategies do they use to frame their positions? Who are the institutional and individual actors contesting these ordinances and what discourses do they use to counter them?

The second research question can be broken out into the following questions about how these decisions influence policy talk and decisions over time:

- How do the tensions between different discursive strategies work to change the course of a policy process? How do actors use different arguments? How do actors use discourses to respond to each other? Which are the most effective discourses at shaping the ordinances? How do local contexts shape both discourses and policy outcomes? 


\section{Conceptual Framework}

This research addresses the gap in understanding how the global and local meet to make policy by providing a look at the very local politics behind neoliberal roll-out policies. The special emphasis is on the discourses of resistance that attempt to counter the hegemonic discourses of neoliberalism. This focus on discourses of resistance helps illuminate how roll-out neoliberalism is enacted at the local level. Neoliberalism and global forces are rolling out new policies to help support market-based reforms and penalize the poor. But the roll out doesn't happen without support and resistance of various actors on the local level.

This research provides an understanding of who the actors are, what actions they take, and how those actions interact to create local policy in a neoliberal context. This is a multiple case study of groups of actors engaging in supporting and resisting sit/lie ordinances in two west coast cities: Portland and San Francisco. As a case study, I use document analysis and in-depth interviewing to explore the actions and discourses by the various groups, as they occur in their political, social, economic, and cultural context of specific cities.

This research adds to our empirical knowledge of how different actors make claims over rights to the city. In addition to informing right-to-the- city and neoliberal resistance theory, this research also has policy and practice implications. In a policymaking realm of diffuse governance where talk about policies matters, this research can help us understand how private actors influence policymaking through discourse. 
This research also has the potential to help those resisting sit/lie ordinances to understand more clearly the forces that support sit/lie ordinances, and thus they can develop new strategies for resistance.

There are many elements that contribute to policy making. These elements are the social relations of power in each context. There are differences at the local level that allow for variations in these policies in depending on the city, including different histories and political structures. For example, civil society in each local place is comprised of a variety of types and numbers of organizations. The number and strength of grassroots actors can help explain who resists, and what type of messages and strategies they use to do so. One can picture a range of strategies that civil rights organizations may use, and contrast that to strategies used by arts and culture organizations. The history of a city's homelessness policies is another important contextual factor. One city may have a history of seeking to contain homeless people in a specific geography, or dispersing people across multiple geographies, or of providing more or less services. These policies may impact the current geography of homelessness, and thus provide context for these new policies that seek to change or re-enforce existing geographies of homelessness. Finally, the formal and informal political system of each place may influence the opportunities for resistance or support.

These contextual differences set the stage for any number of possible actions by supporters and resisters, and thus are important to understand, and are included in this case study. Indeed, the case study design is intended to uncover how those local contexts 
constrain and provide opportunities for discourses of resistance and support (see Table 1 and Figure 1). While these local contexts are important explanatory factors for observed variations, the focus of this research is on the specific actors and discourses used in the agenda setting and policy decision phases of public deliberations about sit/lie ordinances.

Table 1 below provides a summary of the three domains of interest in this study, and the guiding questions and propositions I entered into the research with based on the existing literature. These domains provided a set of sensitizing topics and propositions that I used to guide the research. The literature described above suggested that focusing on the structure of the policy process and policy arenas, the different actors, and the messages they use were important concepts for understanding how and why sit/lie ordinances passed in these cases. The task of this research project was to find out the interconnections between these domains, and to describe and explain in more detail about how each of these work together in policy making.

Table 1: Domains and Guiding Propositions

\begin{tabular}{|lll|}
\hline Domain & Guiding questions & Guiding proposition \\
\hline Interpretive Policy & What happened and & The type and length of the \\
Analysis & when? In what arenas & policy process influences the \\
& do actions occur? & types of actions taken and \\
& the different policy and \\
& message outcomes. \\
\end{tabular}




\begin{tabular}{|c|c|c|}
\hline & $\begin{array}{l}\text { Who were actors } \\
\text { trying to influence? }\end{array}$ & $\begin{array}{l}\text { The type of process used } \\
\text { influences who actors are } \\
\text { trying to sway, and thus their } \\
\text { messaging strategies. }\end{array}$ \\
\hline $\begin{array}{l}\text { Neoliberal/Right-to- } \\
\text { the-city Actors }\end{array}$ & $\begin{array}{l}\text { Who were the actors? } \\
\text { Who puts the issue on } \\
\text { the agenda? }\end{array}$ & $\begin{array}{l}\text { Actors vary depending on the } \\
\text { city elite's location in the } \\
\text { global political economy } \\
\text { and/or the development of } \\
\text { grassroots organizing } \\
\text { sectors. }\end{array}$ \\
\hline $\begin{array}{l}\text { Homelessness/social } \\
\text { movement framing }\end{array}$ & $\begin{array}{l}\text { How do actors use } \\
\text { policy discourses to } \\
\text { influence decision } \\
\text { makers? }\end{array}$ & $\begin{array}{l}\text { The different actors may use } \\
\text { different messages } \\
\text { depending on their missions } \\
\text { and focus. }\end{array}$ \\
\hline
\end{tabular}

The research began with an understanding from the literature that these were likely to be key elements. Figure 2 below briefly summarizes the literatures I have drawn from, and the elements from each literature that I believe are explanatory factors for policy making in these cases. My purpose in the research was to better understand how those different elements interact in policy-making, a project that can only be done by 
drawing through an interdisciplinary lens rather than focusing on the role of just one of the elements. In the figure below the three domains are around the outside, and contribute the four factors in the center circle, actors, tactics, policy arenas, and policy talk/collective action framing. The goal of the research is to explore more the connections within the center circle. Chapter 7 describes those findings and proposes a theoretical conceptualization of how they work together based on the comparative case study analysis.

CONCEPTUAL RELATIONSHIPS BETWEEN EXPLANATORY FACTORS

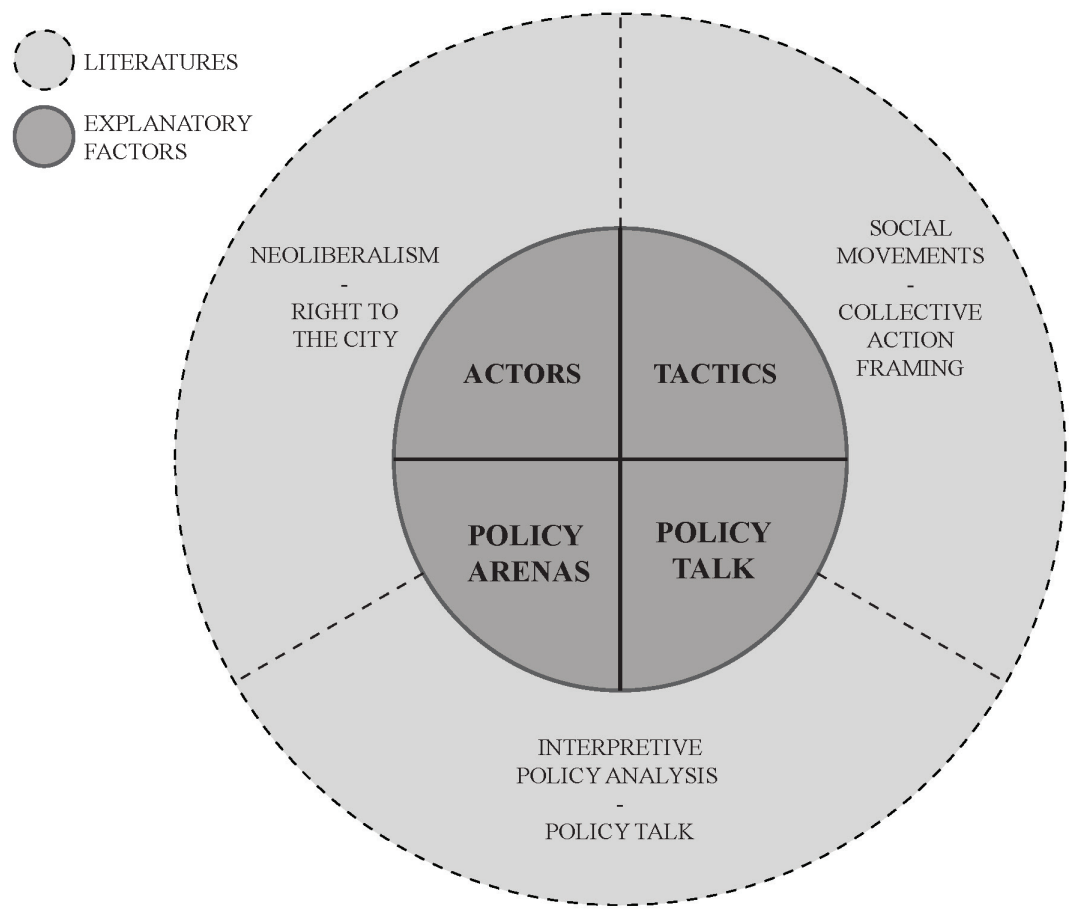

Figure 2: Conceptual Framework

. Previous research has told us that individually these contextual and discursive variations influence policy debates. What is not yet fully understood is how these 
variations interact to create the policies in different cities. This research develops an explanatory theory through comparative case study of how those elements work.

\section{Methodological Approach}

This section describes the methods and analytical approach used to answer the research questions. In it I describe the comparative case study method employed, the sources and type of information collected, case selection criteria, data collection criteria, and analysis strategy - thematic coding and limitations.

\section{Comparative Case Study Approach}

This is a multiple case study of the actors and discourses in public debates around the passage of sit/lie ordinances in two cities. Case studies allow researchers to develop a further "understanding of what causes a phenomenon, linking causes and outcomes" (Flyvbjerg, 2011). In this study, the phenomenon is using sit/lie ordinances to control homeless people's use of public space. This design allows us to see how the debates over sit/lie ordinances, and the local contexts in which those debates occur, shape policymaking. As I developed each case, I employed the use of constant comparison, which is continual interrogation of the data to determine what information fits with the ideas/theories I'm developing, and what doesn't fit. Constant comparison is used often in thematic analysis to compare across cases. It is used in order to develop theory about the observed phenomenon, and is similar to Yin's pattern-matching concept for analyzing case studies (Floersch, Longhofer, Kranke, \& Townsend, 2010; Yin, 2003). Case studies 
rely on analytical generalization, where we "generalize a particular set of results to some broader theory" (Yin, 1984, p. 39). The broader theory here is resistance to the neoliberal city and theory about the right to the city. Comparing multiple cases adds rigor by providing replication logic. The multiple cases may replicate findings to increase the validity of the generalizability to theory.

\section{Case Selection}

Using the table from the National Law Center on Homeless and Policy (NLCHP), described in Chapter 1 and last updated in 2009, as the most complete inventory to current sit/lie ordinances available, I created a list of all possible cases. I added San Francisco to that list as their ordinance was passed in 2010. I then restricted those cities to places within the $9^{\text {th }}$ Circuit. I wanted places that were under the same federal legal context, as the $9^{\text {th }}$ circuit has upheld the sit/lie ordinance in Seattle. Using those cities, I then looked for cities larger than 400,000 people to include. This number was a natural break in the data. I wanted the cities to be large enough to have developed civil society groups, and for the city to have mainstream and alternative newspapers dedicated to that city to have enough available data. This excluded the smaller cities or suburbs of larger cities. The resulting possible cases were: Seattle (1993), San Francisco (2010), Portland (2002 \& 2006 versions), Los Angeles (2002 passage, 2006 enforcement), Phoenix (1962), San Jose (1996), Tucson (1997), Fresno (1968), Sacramento (date unknown). I further narrowed to cases passed since 2000, resulting in the selection of San Francisco, Portland, and Los Angeles. After initially scoping out the Los Angeles case, it became 
clear from organizers and newspaper records that the ordinance passed in Los Angeles was not a stand-alone sit/lie law, but an informal set of enforcement actions being taken as part of other homeless enforcement activities. One organizer told me, "Los Angeles does not have a sit/lie ordinance." Additionally, newspaper coverage at the time did not include any identifiable debate about a potential law, and thus could not have been analyzed for this paper. The homeless policy situation in Los Angeles is something for future research.

There are a group of cities that passed ordinances restricting blocking pedestrian movement by sitting on sidewalks that were passed in the 1960 s, and related to the regulation of counter-cultural movements of that time (Ehrenfeucht \& Loukaitou-Sideris, 2007). Then, following the passage of the Seattle law in 1993 and upholding in the $9^{\text {th }}$ circuit in 1996 there were a group of cities that passed identical ordinances at that time; most of these were smaller suburban jurisdictions. It wasn't until almost ten years later that the larger cities passed similar ordinances, with San Francisco and Portland passing them in a period of five years. This case selection allows me to look at how those different processes, situated in different local contexts (but same federal contexts and time period) effected the different outcomes.

\section{Data Collection and Analysis}

The study uses data collected from three main types of sources: archival documents, interviews with key informants, and a review of secondary data. Documents 
came from three areas: newspaper articles referencing sit/lie ordinances from the main local "newspaper of record" for each city plus at least one alternative paper; written position papers/documents from advocacy groups; working group publications; agendas and minutes of public meeting minutes; and text of the ordinances. Documents provide both a historical record of events and participants for building the case study timeline, and a subset were analyzed for their discursive elements. This helps answer who the actors are and the discursive strategies they employ.

The documents are one historical record of events, but news media often doesn't capture the participation of all the actors evenly. The stories of the most radical participants, low-income participants, and women are often excluded from these accounts. Informal uses of power are also less likely to be covered. Interviews with key informants helped to identify these excluded actors. Interviews also help answer why actors chose particular discursive strategies by asking informants about their motivations and reasons for their actions.

\section{Data Collection Protocol}

This section describes the protocols used for data collection, including types and sources of information. I used a three-step data collection process: collecting data from archival documents, interviews with key informants, and a review of secondary data. Using multiple sources of data can help improve the reliability of the data collected through triangulation (Creswell, 2003). For example, review of documents can help determine which informants to interview and a review of secondary data can help 
validate reports from interviews or published in documents. Table 2 summarizes the sources for the three types of data, and the next section discusses protocol for data collection for each category.

Table 2: Types of Data Sources

\begin{tabular}{|ll|}
\hline Data Type & Data Description \\
\hline Documents & National and local news, written position papers/documents from \\
& advocacy groups, text of ordinances, minutes from local government \\
& public meetings \\
\hline Interviews & Purposive sampling; interviewees are selected due to their role in \\
& supporting or opposing sit/lie ordinances; initial interviewees were \\
& found through preliminary document review, then each interviewee \\
& was asked who else I should interview. The semi-structured \\
& interviews were with 3 categories of participants: public officials, \\
& organizers resisting sit/lie, organizers supporting sit/lie. \\
& National Law Center on Homelessness and Poverty reports \\
\hline Secondary Data & U.S. Census, one-day homeless counts reports, homeless service \\
&
\end{tabular}




\section{Documents}

Documents used in this study came from three areas: newspaper articles referencing sit/lie ordinances from the local "newspaper of record" for each city, plus at least one alternative paper; written position papers/documents from advocacy groups (both for and against); and text of the ordinances and related legal cases.

Newspaper articles. I conducted searches for newspaper articles through LexisNexus and individual newspaper archive databases roughly from 2000-2011 that reference sit/lie, sidewalk obstruction, sidewalk management, and related terms. The newspapers have full online indexing and archives for the time period in question. See the Table 3 for a list of newspapers searched.

Following the search, newspaper articles were included in the sample for content analysis if they specifically refer to the ordinance being debated in each city and include descriptions of at least one of the following: (a) actors involved in sit/lie (pro and con), (b) the need for sit/lie ordinances (diagnostic frames), (c) debate about what sit/lie ordinances will solve, or not (prognostic frames). The selection of individual documents to be saved for analysis is based on the document's relevance for my research question (Altheide, 1996). As such, documents that were included that examine the need for sit/lie ordinances, the resistance to them, or how or why they should work, arguments for or against. Other articles about sit/lie ordinances that are more general or about other cities were used in constructing timelines and context for each city, but were not included in the thematic analysis unless they met the criteria for inclusion. I included and coded 70 
Oregonian articles covering the time period from 2002-2010, and 77 San Francisco Chronicle articles from 2010.

\section{Written position papers/documents from advocacy groups (both for and}

against.) I identified organizations that appeared to play a leading role in the debates around sit/lie in the three cities. These organizations for each city are listed in Table 3. Table 3 also includes samples of the types of documents I collected. I collected position papers or other writings from organization's websites and during interviews. Given the ephemeral nature of websites, it is possible that influential pieces of writing that were once available during the height of the debates are no longer publicly accessible. I asked interviewees for copies of promotional material from the time period in question and received several reports and memos.

Other archival documents. I collected the text of ordinances and policy papers published by government committees to provide background, identify key players, and cross check facts listed in newspapers. I also looked at the minutes from meetings of City Council/Board of Supervisors meetings where sit/lie ordinances have been discussed. I cross referenced newspaper articles that referenced public meetings, and then searched for transcripts or notes from meetings when available. Many of the transcripts were not available, but when they were I used the information to cross-reference facts and processes as described in the newspaper articles. The policy papers and documents were also used to fact check newspapers. In the San Francisco case, these sources include, transcripts from 3 Board of Supervisors meetings or sub-committee meetings, public 
records of campaign finances in San Francisco, and ballot measure text. In Portland these sources included citizen committee reports, legal findings from court cases, ordinance text, and city council minutes from 4 meetings.

\section{Table 3: Document Types Collected, by City}

\begin{tabular}{|c|c|c|}
\hline Type & San Francisco & Portland \\
\hline $\begin{array}{l}\text { Local mainstream } \\
\text { newspaper }\end{array}$ & San Francisco Chronicle & The Oregonian \\
\hline $\begin{array}{l}\text { Local alternative } \\
\text { newspapers }\end{array}$ & $\begin{array}{l}\text { San Francisco Weekly; San } \\
\text { Francisco Bay Guardian }\end{array}$ & $\begin{array}{l}\text { The Portland Mercury; The } \\
\text { Willamette Week }\end{array}$ \\
\hline $\begin{array}{l}\text { Homeless specific } \\
\text { street newspapers }\end{array}$ & Street Sheet & Street Roots \\
\hline Position Papers & Coalition for Homelessness & SAFE Committee Reports \\
\hline Ordinance texts & $\begin{array}{l}\text { Ordinance text; Info from } \\
\text { election of Prop L. }\end{array}$ & Ordinance text \\
\hline $\begin{array}{l}\text { Public Meeting } \\
\text { Minutes }\end{array}$ & $\begin{array}{l}\text { Minutes from Board of } \\
\text { Supervisor meetings when } \\
\text { major hearings were held }\end{array}$ & $\begin{array}{l}\text { Notes and presentations prepared for } \\
\text { city council meetings and/or citizen } \\
\text { committee meetings }\end{array}$ \\
\hline
\end{tabular}




\section{Interviews}

I began the process of conducting interviews by firs generating a list of active participants and organizations through the review of newspaper articles and public meeting minutes. I used these same documents to create a detailed timeline of events and process points in each city. This document review formed the initial list of possible interviews. Then, I used purposive sampling to select interviewees. The purpose was to find people to interview who were most involved in either supporting or opposing sit/lie ordinances, and to have a mix of different perspectives. Those individuals who appeared to be most active in the public debates as covered by newspaper reports were on the initial list for interviews. This list was refined through the interview process by asking interviewees who else was important in the shaping the policy process. During this process, I found that there were a few key actors in each city, fewer participants than I had initially expected.

I attempted to identify initial interviewees from a wide range of organizations from each of three categories of participants (public officials, organizers resisting sit/lie, organizers supporting sit/lie), stated perspectives on the ordinances (for example, those resisting sit/lie may do so for different reasons or with different levels of objection), and type of organization (i.e. law advocacy, homeless advocacy, business, queer groups etc.). At each interview I also asked who else was important in the decisions to begin discussions of sit/lie ordinances, and in supporting and resisting them. 
The final list of interviewees emerged through a combination of the purposive and snowball sampling to come up with as comprehensive a list of participants as possible. The interviews were semi-structured, asking broadly about participants in the political process and motivations behind the individual or organization's work. Interviews ranged between 20 minutes and 90 minutes, with most interviews lasting around 40 minutes. See the appendix for specific questions and interview guide.

I contacted 24 people/organizations that I identified during document analysis as the most involved and/or were referred to me by other interviewees. I conducted interviews with 12 of the 24 people identified. I conducted 6 interviews in each city. The interviewees were almost entirely advocates against sit/lie and government officials. Only one supporter of sit/lie agreed to an interview. Several other supporters actively declined to give interviews on the subject, and others were entirely unresponsive. While the interview data does not include much on this perspective, these actors were interviewed extensively in the newspaper coverage, and also appear in position papers and policy documents that are included in this study, so their policy positions and use of language at the time of the policy debates are included in this study.

The relative lack of interview data from supporters means that this research can speak less to the motivations and decision making of supporters than resisters. This is a disappointing limitation to the research, but also relatively expected. Those with more power and who "win" may not need to prioritize telling their side of the issue or continuing the policy conversation. Those who are actively against the issue are more 
likely to want to continue discussing it, especially in the contexts where the activists are currently engaged in this issue or others.

I was surprised at how few participants were identified as active players in each of the cities. The documents and interview data all identified the same small group of players, with relatively few additional players named by participants in this study. In Portland and in San Francisco, I contacted 12 sources for each city, as potential interviews. Six interviews were completed for each city. The other six potential interviewees from each city either did not return my messages or declined to participate.

Throughout the manuscript, I name current or former elected officials who were talking about their public role. Since elected officials policies, actions, and communications are part of the public record confidentiality was not offered for them. In order to protect other interviewees or their organizations, which often served very vulnerable populations from political or funding repercussions, other interviewees were provided the option of being named or just identified by. Most requested to be identified by role only, suggesting there was a strong concern about political repercussions. In order to maintain consistency and make sure people aren't identified by process of elimination, I only named elected officials throughout this manuscript.

Interviews completed in Portland

Executive Director of Homeless service and advocacy organization \#1

Executive Director of Homeless service organization \#2 
Former Mayor Tom Potter

Commissioner Amanda Fritz

City government staffer, office of neighborhood involvement

City government staffer, crime prevention program

Additional attempted interviews in Portland that were unresponsive or declined to participate:

Former vice president of Portland Business Association. (The primary participant from the Portland Business Alliance (PBA) has since retired and no longer does interviews),

Current president of Portland Business Association (or any other spokesperson, other staff at the PBA did not return any calls, emails, or inquiries via their website.)

Former homeless organizer (unstably housed, unable to contact, but completed a preliminary interview prior to start of dissertation project)

Former Mayor Sam Adams

Former police chief

Commissioner Saltzman

Completed interviews in San Francisco (6/12)

Executive Director at homeless advocacy organization

Organizer at homeless advocacy organization

No on sit/lie ordinance campaign organizer

Former city councilmember Chris Daly

President of neighborhood association in support of ordinance 
Organizer for multi-city homeless advocacy organization

Additional attempted interviews in San Francisco that were unresponsive or declined to participate

Assistant police captain

Yes on sit/lie ordinance campaign manager

Former Mayor Newsome

District Attorney's office

Neighborhood business owner supporter

Former homeless organizer

\section{Secondary Data}

The final category of data collection is secondary data used to describe the context of the case study. This information was essential to further understand the contextual differences between cities. The political, social, and economic climates of the cities may influence several elements: the political opportunities, opportunities for resource mobilization of social movement actors, stress on residents and businesses, etc. All of these elements are in the literature that examines why collective actions emerge and why things get put on public policy agendas. Databases and variables examined are listed in Table 4. 
Table 4: Secondary Data Sources

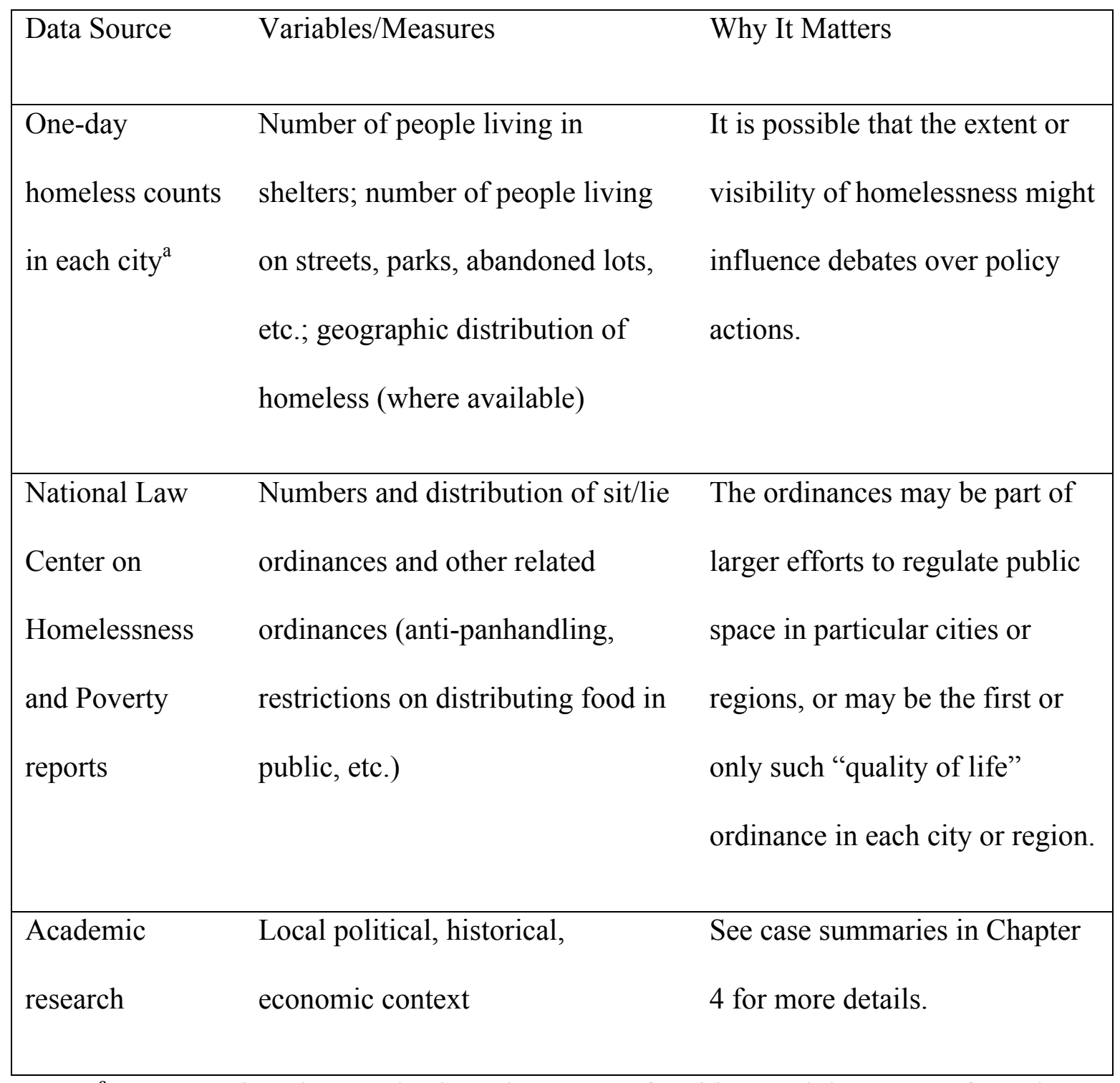

Note: ${ }^{a}$ HUD requires the one-day homeless counts for cities receiving money from them, but cities directly contract researchers to conduct them. The counts utilize volunteers to attempt to contact people in shelters and sleeping in public or private places not designed for human habitation on one set night each year, often in winter. Though limited to point prevalence estimates (the number of people homeless at any one time) rather than over 
time estimates (for example, the number of people experiencing homelessness over the course of a year), they are the best estimates of the comparative sizes of homeless populations available. These are one of the only counts that are done similarly across cities, and some of the only estimates that include people sleeping "in the rough" in addition to shelters. Most other studies only count people sleeping in shelters, and thus undercount as in almost every U.S. city there is a known shortage of shelter beds (Wright, Rubin, \& Devine, 1998). While there are a few things all cities are required to study, there is also much variation between the studies done in each city, so not all the data is directly comparable.

\section{Analytical Strategies}

The analysis of qualitative data is an iterative, reflexive, and cyclical process. Often, data collection and analysis occur simultaneously and inform each other. The three-step data collection process ranging from archival documents, interviews and secondary research described above also requires a multi-step data analysis process. The first step is to build the details of each of the case studies. The secondary data and initial document review provided descriptive details for each case including demographic information, a timeline of events, and descriptions of key participants. Interviews were used to confirm or call into question these details as reported in the press, and provide information about actors' motivations and goals. The second step is to conduct the thematic coding of the interview data, news reports, position papers, etc., for each case. The third step is to compare the descriptive information and 
themes from each case to the other cases. Throughout this three-step process, I used constant comparison as described earlier in this chapter.

\section{Qualitative Thematic Coding}

The focus on discourse allows us to see how multiple and conflicting discourses in the public sphere shape the policy debates, and how certain discourses take prominence over others (Marston, 2004). I used thematic coding (Braun \& Clarke, 2006) to identify how neoliberal forces and resisters communicatively shape policymaking through claims-making arguments of supporters and resisters. Thematic analysis is a "commonly used qualitative method to identify, report, and analyze data for the meanings produced in and by people, situations, and events" (Floersch, Longhofer, Kranke, \& Townsend, 2010, p. 408) It is a flexible analytic strategy that is compatible with many research approaches including constructionist ones that, "examine the ways in which events, realities, meanings, experiences and so on are the effects of a range of discourses operating within society" (Braun \& Clarke, 2006, p. 81). I used line-by-line coding of the newspaper articles and interviews.

Analysis of discourses was done through line-by-line coding of documents and interview transcripts. I used "open" coding, looking for latent themes that help us to understand meaning from the words of the informants and writers. Latent themes, "go beyond the semantic content of the data, and starts to identify or examine the underlying ideas, assumptions, and conceptualizations - and ideologies - that are theorized as shaping or informing the semantic content of the data" (Braun \& Clarke, 2006 p. 84) In 
this interpretive framework, the creation of codes and themes is an analytical task that recognizes that meaning is created through a combination of author intent and the reader's interpretation ( Braun \& Clarke, 2006).

However, while I'm looking for meaning in their words, I am not a blank slate. I come with ideas about what is important, based on previous research and personal experience. I also have read academic literature that has sensitized me to certain concepts (collective action frames, political regimes, right-to-the-city discourses, etc.) that are likely to seem important to me as a researcher with a particular disciplinary and life history. I also continued to seek out alternative explanations, new themes, and interpretations as I analyzed each new document and interview.

A preliminary review of a few documents from each source was used to create an analysis framework with categories that capture different discourses. Using another few documents from each category, I tested the categories and adjust the categories to fit (Altheide, 1996). Some of the themes were theoretically driven based on other findings documented in the literature, and other themes emerged from the content.

I used ATLAS Ti to help facilitate the coding. During this coding process I created memos that included: notes on my reasons and definitions of codes, connections between codes that might suggest larger themes, thoughts on what I've learned thus far about the case, and other questions I have, findings that are consistent or inconsistent within and between cases, and assumptions I'm making. It is this memo-ing process that some of the more analytical tasks in qualitative research first emerge (Floersch, 
Longhofer, Kranke, \& Townsend, 2010). Following this open coding process, I looked for connections and similarities between codes that suggest larger themes (Braun \& Clarke, 2006).

\section{Limitations/Ethical Considerations}

Data from interviewees were limited by participant availability and willingness to consent to interviews. This is one example from critical/feminist perspectives that demonstrates the co-constructed nature of knowledge creation through research. The data I collect, and how I analyze it, is intimately connected to the information and perspectives that interviewees are willing and able to share, and of my situated understanding of that information. I attempted, however, to conduct interviews with as many participants as necessary to achieve "saturation" of themes. This saturation was achieved for the groups opposing sit/lie ordinances in each city, but not enough politicians or supporters agreed to be interviewed to reach this threshold for those two groups.

By using both purposive sampling of a list of interviewees generated through document review and interviews, I attempted to generate a large enough list to not miss key perspectives. However, there were a large percentage of key participants that did not want to be interviewed. The majority of those who I was not able to contact or who refused interviews were supporters of the ordinance, which substantially limits what this research can tell us about their motivations and decisions. The research can and does, however, highlight the policy talk, positions, and political moves they took as described in the public record. In general, resisters to sit/lie ordinances were more eager to talk 
with me. It was not possible to contact several of the homeless activists though, who have especially complicated and transient lives. 


\section{Chapter 4: Case Study Histories}

This chapter provides brief case summaries of the economy and form of government in Portland, Oregon and San Francisco, the two cities that are the focus of this research. Also covered in this chapter is the geography of homelessness and history of sit/lie ordinances in each city. This historical context is important to interpreting the events, actors, and actions in each of cases described. This chapter also provides a short summary of key events in the policy process in each city, and key actors found to be important and influential in the process. This chapter is descriptive and provides a base of understanding for the context of the cases; subsequent chapters analyze and interpret the events in detail and compare and contrast across cases.

\section{Portland}

\section{Economy and Form of Government}

Portland is the largest city in Oregon and is smaller than San Francisco. Oregon has only two Fortune 500 company headquarters: Nike, headquartered in a Portland suburb, and Precision Castparts, a company that makes airplane engine parts, is located in Portland. Rather than having an economy based on large transnational corporations, Portland is instead known for locally owned small businesses rather than global capital industries (Heying, 2010).

Portland has a unique form of government. The city commission government system includes four city commissioners and a mayor, who are elected at large 
throughout the city, not representing neighborhoods or districts. Each commissioner is also the head of a city bureau - putting control of the everyday management of the city into an identifiable elected leader, rather than a professional city manager. Some argue this makes government more responsive to citizen needs. This responsiveness to citizen needs and use of neighborhood based "consensus politics" is often cited as a unique feature of Portland's governance structure (Johnson 2004). However, this consensus politics is also critiqued as limiting more radical approaches and rewarding cooperation (Abbott 2001).

\section{Geography of Homelessness}

Portland's Old Town area has been the historical home to low-income single men and, increasingly, women. Historically, the area was filled with single room occupancy (SRO) housing for people involved in the shipping and logging industries. While those industries are largely gone, Old Town is still the geographical center for the "chronically homeless" (those living on the streets for many years, with co-occurring mental health and addictions disorders). Other low-income communities are found farther out from the downtown business district and in suburban jurisdictions.

Today there are a number of social service providers, temporary shelters, and lowincome housing providers concentrated in the Old Town area. The area is bordered by the downtown business district and the recently gentrified Pearl district. The Pearl district is a re-development area that was once filled with low-income housing, light industry, 
and rail yards, and is now home to high-rise apartment and condo buildings and upscale retail.

In 2011, Portland enumerators found 4,655 homeless people in Multnomah County, with most people located in the City of Portland. Of the 1,718 people identified as sleeping on the streets (rather than in shelters or transitional housing), 20\% reported that they intended to sleep in Old Town or downtown Portland. While the report does not publish the numbers of shelter and transitional housing populations by geography, the concentration of those services suggests that a large percentage of the additional 1,009 people in that category were also in the Old Town/downtown area. Of all the homeless surveyed, nearly $46 \%$ identify as people of color, compared to $29 \%$ of the general population in Multnomah County (2011 Point-In-Time Count of Homelessness in Portland/Multnomah County, Oregon, 2011). In 2010 there were 583,776 people in Portland (U.S. Census), for a homeless rate of $0.80 \%$ of the population.

Portland is known for having some of the more developed social services for those experiencing homelessness, and some of the best working relationships in the country between service providers, government, and the police (personal interview, National Law Center for Homelessness and Poverty, 12/2/2008). These close connections and a history of consensus-building policymaking may help to maintain a certain level of social services, but it also means that service providers are less able to engage in confrontational politics (Abbott, 2001).

\section{Sit/lie Ordinance History}


Cities have been regulating behaviors and uses of sidewalks for a long time, so sit/lie regulations are nothing new. However, the targets of the ordinances are. The 1993 passage of an ordinance restricting sitting and lying on sidewalks in Seattle was the start of the current period of sit/lie ordinances. In that time, Seattle was going through a major downtown redevelopment process as part of their emergence onto the world city stage as Microsoft and other technology companies started to boom. Seattle was trying to attract redevelopment into downtown, and in the process low-income and no- income people were displaced from the area. In 1996 the 9th circuit court of appeals upheld the ordinance as constitutional on its face as sitting or lying are not commonly expressive activities. After this ruling, a number of other jurisdictions enacted similar legislation along the west coast. Most of these jurisdictions were in California suburbs.

Around that time in Portland, there was discussion of ordinances allowing more uses of sidewalks. In the mid-1990s Portland relaxed regulations to allow for sidewalk café seating and sidewalk advertising signs - both strategies intended to help foster business development in the central business district. In 2002, however, the policy discussion in Portland changed and the first conversations started about using laws to restrict the visibly poor from public spaces.

The history of the sit/lie ordinance in Portland spans nearly a decade and is filled with multiple attempts to create an ordinance and multiple legal challenges. January 2002 is the first appearance in the local paper, The Oregonian, of a discussion concerning an ordinance that would restrict people from sitting or lying on sidewalks. After several 
months of debate, Mayor Vera Katz announced that instead of attempting to get a new sit/lie ordinance passed, the city would increase enforcement of current laws that prohibit obstructing sidewalks (Leeson, 2002). On September 19, 2002 "dozens of people” protested the enforcement of these rules outside city hall (Nakamura, 2002). The next day The Oregonian reported that police had used the sit/lie ordinance to remove 10 Cascadia Forest Alliance members participating in a political vigil in the residential neighborhood of Irvington (Rose, 2002). This appears to be the first time the mainstream newspaper The Oregonian reported an instance of people being told they could not "sit or lie" on the sidewalk. Mainstream print news coverage of protesters affected by the ordinance continued into August 14, 2003 when a group of anti-war protesters were arrested under the sit/lie ordinance (Stern, 2003). Two days following this use of the ordinance against protesters, there was a demonstration in front of City Hall to protest using the ordinance; one person was arrested for lying across the sidewalk (Heinz, 2003a). Later that evening, an additional five people were arrested for blocking a sidewalk while protesting outside City Hall (Heinz, 2003b).

Almost one year later, on June 23, 2004, the sit/lie ordinance was declared unconstitutional by a Multnomah County judge (Green, 2004). In this case, the law had been used to remove the anti-war protesters, and the court found that the ordinance restricted the constitutional right to peaceful assembly (Green, 2004). One of the people arrested for the protest argued that the sit/lie ordinance was intended to limit political protest, and mentioned that he was arrested eight hours after the law went into effect 
(Green, 2004). In November of 2004, another sit/lie ordinance was passed to replace the one declared unconstitutional.

In May of 2006, the then mayor, Tom Potter, announced the formation of a study committee to look at renewal of the sit/lie ordinance that had been passed 18 months prior (Griffin, 2006, 2007). The downtown businesses association, the Portland Business Alliance, had requested that the mayor begin this new process to help them deal with the homeless in the downtown areas who were blamed for reducing the number of consumers in the central business district (Personal Communication, Portland business Association, March 7, 2008).

From June through December 2006, community groups and local government officials met to create the Street Access for Everyone (SAFE) committee (Potter, Rubio, \& Reynolds, 2006). The citizen advisory commission was comprised of business leaders from the local Business Improvement District (BID), representatives from the mayor's office and police bureaus, homeless service providers, homeless activist groups, and legal organizations including the ACLU. This committee's report, published in December 2006, kicked off another round of policymaking that tied provision of social services for homeless with the passage of an ordinance restricting sitting or lying on the sidewalk (Rose, 2006).

On December 14, 2006, the city council voted to move forward with the sit/lie ordinance that was presented by the SAFE coalition, which tied regulation to providing restrooms, day access centers, and benches (Rose, 2006). Nearly five months later, The 
Oregonian reported that the new sidewalk obstruction ordinance would soon go into effect due to the progress made on providing services (Griffin, 2007). At this time, the mayor's office announced there were now some new benches in the Old Town/Chinatown neighborhood, and that one restroom had been renovated (Griffin, 2007).

Citing these improvements, the mayor recommended the council vote on final wording of an ordinance. The council had been withholding enforcement until after an August 1, 2007 city council meeting where they approved a contract to have the Portland Business Alliance and the city collaborate on policing for the Clean and Safe program (Portland City Council, 2007). Two weeks later, on August 15, 2007, the council voted to approve the recommendations of the SAFE initiative, thus beginning enforcement of the policy (Portland City Council Meeting, 2007). Enforcement of the ordinance began in 2007 and was again found unconstitutional in 2009 because the ordinance was found to "unconstitutionally exceed the city's authority." In 2010 the city passed a new ordinance.

\section{San Francisco}

\section{Economy and Form of Government}

San Francisco is now a city whose economy is tied very directly to the .com boom-and- bust cycles, but unlike nearby San Jose, it also has a significant number of international corporations in the finance, insurance, and banking sectors. However, the economy hasn't always been so connected to global capital. Until 1958 there was only 
one high-rise in downtown San Francisco, and the city functioned more as a regional driver than a global one (Hartman, 2002). However, starting in the late 1970s the development regime was able to transform downtown San Francisco by building up and out (Hartman, 2002). One example of this change was the development of the Yerba Buena center redevelopment plan that bulldozed most of the South of Market neighborhood that housed many low-income poor men in the area in SROs, replacing it with a highly policed park, admission-based museum projects, and an indoor shopping mall. The development regime has been countered in many instances by a progressive regime that has been especially active and effective around environmental and queer issues (DeLeon, 1992).

The City of San Francisco is a strong mayoral form of government, which includes a board of eleven supervisors elected to represent districts in the city and overseen by the mayor. The boundaries of the city also overlap with the entire County of San Francisco, merging two political boundaries into one geography. The city has a history of liberal policies and a developed grassroots network (DeLeon, 1992).

\section{Geography of Homelessness}

Homelessness is often identified as one of the largest social issues in San Francisco, and has been one of the major issues in recent mayoral campaigns. In 2003, Gavin Newsom was elected mayor in part on a controversial "Care not Cash" homelessness program that, once enacted, changed the type of services provided to those who were homeless. Following its enactment, the city stopped funding cash subsidies 
that had gone directly to individuals and shifted it to social service providers for programmatic support instead. This controversial approach was selected to be able to control what homeless recipients of used the resources for. Instead of getting cash that they could use to purchase anything, homeless individuals were required to connect to social service providers to meet their needs. Providers have had limited success in developing more low-income housing in one of the most expensive real estate markets in the country, and there are still not enough shelter beds or health services for all those in need (Murphy, 2009).

The chronically homeless population is largely concentrated in the Tenderloin district in the area between Union Square (the downtown shopping district) and the Civic Center area, home to city hall and large cultural institutions such as museums, ballet, and opera. There are also visible homeless populations in the South of Market area (which prior to the redevelopment of the Yerba Buena Center with a park, retail, and museums, was largely SRO housing) and in and around Golden Gate Park, and especially in the panhandle neighborhood near the historical counterculture center of Haight/Ashbury.

The one-night homeless count in 2011 found 6,455 homeless in the City of San Francisco, with almost half being unsheltered. Sixty nine percent were concentrated in two supervisory districts. Forty percent were in District 6, which includes the Tenderloin and Civic Center neighborhoods, and 33\% in District 10, which includes Bayview/Hunters Point. About 35\% identified as Black/African American, compared to about $6 \%$ of the larger population of the city (2011 San Francisco Homeless Point-in- 
time Count \& Survey: Executive Summary and Comprehensive Report, 2011). In 2010, there were 805,235 people in San Francisco city (U.S. Census), with a homeless rate of $0.80 \%$ of the population

In a 2009 report, the National Coalition of Homelessness placed San Francisco in their list of the top 10 list of meanest cities for the homeless, largely due to the number of citations for things like blocking sidewalks, sleeping, or camping issued to people experiencing homelessness (Homes not Handcuffs, 2009). They rate meanness by the "the number of anti-homeless laws in the city, the enforcement of those laws and severities of penalties, the general political climate toward homeless people in the city, local advocate support for the meanest designation, the city's history of criminalization measures, and the existence of pending or recently enacted criminalization legislation in the city" (Homes not Handcuffs, 2009).

\section{Sit/lie Ordinance History}

In early 2010 the Board of Supervisors of San Francisco began discussing a sit/lie ordinance. Grassroots opposition mobilized campaign using street theater and a day of action modeled after the "parking day" protests in order to raise the issue in the public eye and to garner opposition to the law by progressives on the Board of Supervisors. In June, the Board of Supervisors voted down such an ordinance. The ordinance was put on the November ballot by Mayor Newsom as Measure L and passed in November (54\% yes votes) (City of San Francisco Department of Elections, 2010). This ordinance came on 
the public radar and was passed in less than one year. Enforcement of the ordinance began in April 2011.

This was the only ordinance to be voted on in a public election, perhaps changing the dynamics of the public debate. The activist groups were from a much wider range of organizations, including a large contingent of queer activist organizations, housing rights organizations, and civil rights groups. These groups had a broader range of protest activities including arts-based protest actions and voter campaigns. In contrast to Portland's ordinance that covers a specific set of neighborhoods, the San Francisco ordinance covers the entire city. In Portland, a homeless person could leave the restricted area and be able to sit on the sidewalks in other parts of town. In San Francisco though, they would have to leave town entirely. Breaking the law is a criminal offense, where as in Portland it is a civil offense.

\section{Conclusion}

These histories and contexts inform the actors, policy talk, and arenas available for policy-making in each of the cities. In the following chapters I provide more detail on the policy process in each of the cities. Then in the final chapters I compare similarities and differences across the two cities, highlighting findings for practice and theory. 
Chapter 5: Portland, Oregon

This chapter provides a brief overview of the nearly decade-long policy process in Portland around sit/lie ordinances, focusing on four significant timeframes. These timeframes delineate four distinctive policy approaches in different policy arenas. Further discussion describes how the actors use a variety of discursive strategies over time. The chapter concludes with my argument that the very local policy process structures opportunities and venues for involvement in the creation of laws.

\section{Actors and Data Collection}

Over the course of about a decade there were multiple actors involved in sit/lie ordinances in Portland. From city government several administrations of mayors were involved, including Mayor Katz, Mayor Potter, and Mayor Adams. The Portland Business Alliance has been the primary organization representing business interests. Neighborhood associations, and especially the Old Town/Chinatown neighborhood association have played minor roles periodically, mainly by hosting community meetings where the topic was occasionally discussed, often by the business owner members. Three homeless advocate/service organizations have been particularly involved, including most notably Sisters of the Road, Join, and Street Roots. Finally, the ACLU and Oregon Law Center were also participants.

For this study, I spoke with former Mayor Potter, Commissioner Fritz, staff at the City's Department of Neighborhoods, organizers with Sisters of the Road, and the 
executive director of JOIN (who was previously at the Oregon Law Center). I also spoke with an organizer from the Western Regional Advocacy Project (WRAP), a national umbrella organization working on this issue in both Portland and San Francisco. I also reviewed 70 articles published in The Oregonian covering the time period, as well as numerous public meeting agendas, minutes, and policy documents. The primary participant from the Portland Business Alliance (PBA) has since retired and no longer does interviews; other staff at the PBA did not return any calls, emails, or inquiries via their website. Other previous government officials also declined to schedule interviews. One particularly influential homeless organizer was unable to be reached for this project, as he is unstably housed and no longer affiliated with his prior employer, however I did conduct a pre-dissertation scoping interview with him.

\section{Policy Arenas and Time Periods}

Unlike other cities that have passed sit/lie ordinances quickly and with little public discussion, the policy process in Portland has continued on and off for over a decade. This study covers the time period from roughly late 2001 through early 2010. During that time, there have been four significant processes through which policy making and re-making has happened in Portland.

- First, from 2001 to 2002 , the city tried to adjust administrative rules to enforce existing laws against the poor.

- Second, from 2002-2005, there were a series of legal challenges to existing laws. 
- Third, from 2006-2008, the city convened a formal collaborative citizenbased task force to create a new ordinance.

- Finally, from 2008 - 2009, a fragile collaboration falls apart and social actors turn to protest.

Broadly speaking, these are types of policy-influencing arenas that both structure policy discourses and are structured by policy discourses. Looking more deeply at these four arenas we can see how those structure the policy talk, and how policy talk influences decision making.

\section{1-2002: Administrative Rewrites To Enforce Laws Against the Poor}

The period from about 2001 through 2002 was a time of administrative rewrites. The city administration quietly began rewrite to adjust many municipal codes, including codes regulating sidewalk behavior. There was an ordinance already on the books at that time that required a pedestrian through zone which regulated a required distance that had to be free for pedestrians. However, the law was rarely enforced and the city knew the law was too broad and likely unconstitutional, so they began making some changes. Homeless groups, led by JOIN, found out about these changes and pushed back saying changes would be substantive not administrative. The changes would have a disproportionate impact on the homeless, so the homeless groups and called for public participation in the changes. 
The city did not make changes to sidewalk regulation portions of the code at this time, but eventually released some enforcement guidelines to try to overcome being overly broad, and to avoid conversations about changing the code. None of the parties really supported this solution. The police department pushed for changing the ordinance because the pedestrian through zone required police to have precise measurements. Additionally, the business association wanted a more aggressive ordinance that could be enforced. Some resisters also weren't happy about it, despite limited enforcement.

\section{Policy Arenas - Administrative Rewrites}

In 2001 the city began overhauling Title 14 of the city code: Public Order and Police. There had been code on the books "a very long time" (Dec 152004 Council minutes) that restricted nuisance obstructions from sidewalks. However, it was no longer being enforced because the city attorney's office thought the law was likely vague, too broad, and didn't allow for some activities that may be protected under the first amendment. Members of the homeless activism community agreed that there were some legitimate rewrites needed to reflect updates necessary due to other court rulings, and to make it more organized. However, they objected to one of the suggested changes. There was a proposal to combine the sections about pedestrians and obstructions as nuisances. This would re-define people on the streets as possible obstructions.

The Oregon Law Center identified this as harmful to homeless people and organized a swift response to council (personal interview homeless advocate). This response, much of it out of the public view (i.e., in meetings with commissioners, not at 
council meetings) caused the city to decide to only make the non-controversial changes and to hold off on the changes affecting pedestrians as nuisances. At the council meeting where the council voted to only implement the non-controversial changes, Mayor Katz announced that the city would address the more controversial aspects of the re-write separately and through a public process. At some point in the course of the next year, the city developed enforcement guidelines that they hoped would overcome the known constitutional deficiencies in the law.

\section{The Policy Discourses - Administrative Rewrites}

This time period, 2001-2002 was a formative agenda setting phase of policy making. Since much of it happened in administrative meetings, there are very few public records to examine. In January of 2002 The Oregonian newspaper first started reporting on discussions of various proposals for removing the visibly poor from the streets. The policy talk at the time was varied, indicating that no one policy solution or framing had taken precedence in public conversations. In fact, there were a number of proposals put forward. Suggestions for policy solutions ranged from restricting sitting on benches if it "interferes with the public's ability to enjoy the bench," or increasing enforcement of already existing anti-nuisance laws, to implementing a sit/lie ordinance "like Seattle."

These solutions were very focused on details, which is to be expected in an administrative frame, rather than big picture decisions about the goals and approach of such an ordinance. For example, in a series of articles from January 2002- September 2002 the coverage focused on details of the rules including a short summary of who, what 
and when the ordinance would be enforced. The Oregonian reported that the sit lie ordinance “... bars people from lying, sitting or kneeling on a public right of way in a portion of downtown from 7 a.m. to 10 p.m."

In addition it focused on how it would be enforced, noting there would be a need to give a warning as well as have a witness. For example, The Oregonian wrote: "The new guidelines also require that police give suspects notice and a chance to clear an improper blockage before issuing any citation.", and further "the district attorney's office won't prosecute people blocking the sidewalk without a witness who can testify that they were blocked"(Learn \& Oliver, 2002; Stern, 2002).

Opposition to a new law was palpable, and confrontational. Representatives from the Oregon Law Center, the ACLU, Dignity Village (a homeless encampment and advocacy group), and at least one city commissioner all spoke out against increasing criminalization of the poor. The Oregonian summarized their position by saying, "But civil rights advocates are attacking the code rewrite, saying that changes would violate constitutional rights and would allow police to selectively enforce laws against the poor." (Learn \& Oliver, 2002). Mayor Katz went on record to say that the city would not be pursuing a sit/lie ordinance because, "We made an early decision that sit/lie was unconstitutional under Oregon law," Katz said. "We're not going to go there" (Leeson, 2002). While that would appear to be a decisive end to the policy discussion, it turned out to be only the beginning. 
The evidence suggests that organizations supporting tourism and economic development continued pushing for new regulations, rather than just increased enforcement guidelines for existing laws. The visitor's association pushed hard for an ordinance, telling the city council that tourists had been complaining about homeless people on the sidewalks, testimony that made it into the newspaper reports: "Last week, the chief executive of the Portland Oregon Visitors Association told the City Council that some tourists had expressed concerns for their safety on downtown streets" (Leeson, 2002).

Suggestions for policy solutions included restricting sitting on benches if it “interferes with the public's ability to enjoy the bench," or increasing enforcement of already existing anti-nuisance laws. Organizations supporting tourism and economic development continued pushing for new regulations. The visitor's association lobbied hard for an ordinance, telling the city council that tourists had been complaining about homeless people on the sidewalks. Eventually, the least restrictive and the most restrictive policy options that were discussed at the time were abandoned.

Shortly thereafter, The Oregonian reported that Mayor Vera Katz, "recently announced her strategy for stopping people who are homeless from sitting on city sidewalks: Arrest them" (Currie, 2002). A few weeks later Mayor Katz released a report suggesting she was willing to support quality of life ordinances, of which sit/lie is one. In the report, she specifically connects economic development and quality of life, saying they go "hand in hand" (Learn \& Oliver, 2002). A few months later, the city issued new 
guidelines for enforcing an existing "obstructions as nuisance" law, which many people understood as giving direction to arrest the visibly poor.

This reversal highlights the successful framing of economic development as a need for the ordinance. Despite initial resistance to increased criminalization of the visibly poor by human rights organizations, homeless service and advocacy organizations, and elected officials, the business interests successfully passed a new law using economic development and tourism as justifications. The focus on tourism is perhaps not surprising. The nation was in the middle of air travel slump following the terrorist attacks of September 11, 2001 as business and leisure travelers cut down on travel, and business and government leaders were looking for ways to draw those dollars back.

\section{2 - 2005 Legal Challenges and New Laws}

This solution of enforcing the "obstructions as nuisance law" remained in place until the ordinance was used against protesters. This action triggered legal opposition and local protests on the basis of limiting rights to protest and free speech. The ordinance was declared unconstitutionally overbroad, just as the city had previously surmised. At this point, the city created a new ordinance, with limited citizen involvement, that was set to automatically expire, or sunset, in 18 months. This new ordinance was also shut down by courts, referencing state law requiring intent to block the sidewalk that would preempt the local law. A separate appeal also stated that it couldn't be enforced without enough shelter beds. 
The result of these enforcement changes didn't last for long though. Renewed resistance roared in September of 2002 when the ordinance is used to disperse protesters from the Cascadia Forest Alliance who were protesting federal logging policies. Community organizations, including homeless organizations, quickly convened a protest at city hall. Using the law against protesters spawned a debate about the ordinance infringing on rights. The right to protest is a long-respected right, and protected under the law, much more so than the right to use the sidewalk for sitting or sleeping. Even the City Attorney commented publicly that sit/lie was not supposed to be used on protesters unless they are blocking access to a building. This event sparks the first of many legal challenges in Portland against the law. Those protesters brought a legal suit against the city, seeking to have the law declared unconstitutional.

Several years later, in June 2004, a Multnomah County judge ruled the original ordinance was unconstitutionally vague and overbroad because it could potentially restrict the right to assemble peacefully, and regulated arbitrary and discriminatory behaviors that the public would have difficulty knowing what is prohibited and what isn't. Following this ruling and with little official discussion, the city council voted a few months later to adopt a new sidewalk ordinance limiting groups of three or more from sitting or standing in pedestrian zones. This December 2004 ordinance regulates anyone who "sits, kneels, or creates a trip hazard or obstruction" in a pedestrian area, stands in groups more than three, leans on a step or ledge that impacts the pedestrian zone, or blocks a sidewalk amenity, among other things. It created a through pedestrian area, in 
which people could not sit. Sitting was allowed in the furniture (area near curb) or frontage (area near business) zones.

This new ordinance was informed by the work of an informal group of stakeholders who met every other week to talk about a rewrite to the code. As an unofficial group, their records are not part of the public record, but testimony at city council meetings implies that there were business groups, homeless and civil rights advocacy groups, and even representatives from various council member's staffs present. The group did not come to a consensus on the new changes, but Commissioner Sten's office brought the recommended changes to the council to vote on anyway, while making the objections from advocacy groups known. The changes, perhaps because of lack of consensus, were set to sunset after 18 months, and the program was deemed a pilot. The city and advocates wanted to track whether it would be unfairly enforced against homeless people in practice.

In 2005 this new ordinance was also found unconstitutional by a Multnomah county court of appeals. The Multnomah county appeals court reversed the lower court decision that would prosecute someone for sitting in a pedestrian zone. The court ruled the ordinance was pre-empted by a state law that requires intent to block the sidewalk as a prerequisite for enforcement. The Portland ordinance affected all blocking of the sidewalk, while the state ordinance required intent to block as a protection for freedom of expression. In 2006, the $9^{\text {th }}$ circuit court of appeals ruled that sit/lie ordinances can't be 
enforced if there aren't enough shelter beds in a city. This was the final nail in the coffin for that ordinance and was the start of another round of policy negotiations in Portland.

\section{Policy Discourses - Legal Challenges}

The debate during council meetings centered on pedestrian access, or as Bloomly might call it, pedestrianism. In December 2014 a staff person at the city attorney's office was quoted as saying, "Here are the rules that I was told to write into code language. Prohibit all uses inconsistent with pedestrian traffic. And protect that function at all hours" (personal interview). This framing focuses on the uses of the sidewalks for pedestrian movement, which makes sitting or lying counter to that use. This framing is also intended to be more broad than just sitting or lying, here the focus is on "all uses." Any counter to this framing would need to address the fundamental assumption that sidewalks are for movement or that it impacts all uses or users the same way. Resisters decided to focus on the disparate impact on certain users saying, "The second concern for me is the enforcement piece... That's going to be a question of how it gets -- of how this gets applied on the street." (Sit Lie, 2004) In this framing, resisters were able to highlight

the disparate impacts on certain vulnerable populations, and we start to see the re-framing from pedestrianism to the impacts on homelessness. In this time period, as highlighted in this example quote, the resisters approach was to express concern that the criminal punishment for breaking this ordinance was unfair and that the law would be unfairly used against homeless people. 
While organizers were trying to draw attention to the impacts of a sit-lie ordinance on homeless people, there was a highly publicized use of the law against a different group of people, protesters. The use of the ordinance to arrest anti-war protesters gave resisters another angle to highlight a different use of sidewalks other than pedestrianism. By focusing on protest actions that happen on sidewalks, they were reframing the debate by arguing that sidewalks are places for the protection of free speech. For example, one Oregonian article after the law was struck down highlighted the response of one of the protesters who was arrested under the sit-lie ordinance saying the protester, “...praised the ruling Wednesday, accusing the City Council of changing the ordinance last August to target his group. He said he was arrested eight hours after the changes went into effect. "It was obvious it was a direct attempt to get rid of a legitimate demonstration," Kurylowicz [the protester] said.” (Ashbel Green, 2004). This highlights the focus on protest as a "legitimate" use of the sidewalk.

Both of these narratives of resistance served to counter the pedestrianism narrative by highlighting different legitimate uses of the sidewalk. This narrative was reenforced by the legal rulings of the time, and was highlighted in newspaper reports. For example, the Oregonian reported, “Adam Scott Arms, a Portland attorney who represented the three protesters, praised the ruling, saying that sidewalks are a historic place for people to express themselves under the First Amendment. 'Sidewalks are sacred ground,' Arms said. 'The city failed to meet the constitutional requirement that restrictions on sidewalk activities be drawn as narrowly and specifically as possible to be 
sure not to infringe on people's constitutional rights,' Arms said."'(Ashbel Green, 2004). However, the supporters maintained a narrative of pedestrian through zones. This allows the group supporting the ordinance to rely on themes of pedestrianism to depoliticize and distance from homelessness, perhaps because of the heightened concerns of unconstitutionality.

\section{6-2008 Citizen Stakeholder Involvement}

Following this court decision, the policy process then moved into a second phase of citizen involvement to craft a new ordinance. Then Mayor Tom Potter initiated a citizens committee that was tasked with researching the issue and suggesting a policy solution. The Sidewalk Access For Everyone (SAFE) committee was comprised of the Portland Business Association, individual businesses, neighborhood associations, homeless service providers and advocates, and civil rights advocates. Mayor Potter selected this policy process based on his approach to governance; he used citizen committees for a variety of issues during this time period (personal interview). Also around this time, the 10- year plan end homelessness was also going on - which started to bring some of these same people together anyway. That focus on services may have impacted the conversation going forward and carrying into the SAFE committee process.

The committee came up with a five-point plan, which included passing a law regulating sitting or lying on sidewalks, but also called for increases in services such as benches, bathrooms, and day use areas in the downtown core. This was a compromise solution with community oversight. The pro forces "won" an ordinance; anti-forces 
"won" an oversight committee, a change into a less harmful type of infraction, and some additional services. During this enforcement oversight process, the multi-party stakeholder collaboration fell apart, leading to the fourth phase of the policy process.

\section{Policy Arena - Citizen Advisory Committee}

In 2006 the city of Portland, with a new mayor, Tom Potter, took a new tack. Perhaps wary of the legal opposition, instead of pushing through regulations with little public comment, he decided to appoint a citizen commission to craft a new solution. This committee, called the Street Access for Everyone (SAFE) committee was an advisory board to the city council. It was comprised of homeless service providers, civil rights organizations, business leaders, the police bureau, and members of the mayor's office. These were many of the same groups that were on the streets protesting and in the courtrooms arguing during the past several years. In 2006 this committee released a report that would shape the debates about sit/lie in the coming months. In it, they presented a plan to enact a sit/lie ordinance similar to the one passed in Seattle in 1993

and that was already upheld by the $9^{\text {th }}$ circuit. In exchange, the business groups and city government would support more services for the homeless in the form of additional benches in public space, a day access center, and a public restroom. The services advocated for are relatively easy to enact and take little public investment or infrastructure. They don't include longer term planning for affordable housing, affordable health care, or ways to increase income for the very poor.

\section{Policy Discourses - Citizen Advisory Committee}


The central framing points during this time were the need for services for the homeless along with an ordinance to help police, “ It's a strategy Mayor Tom Potter announced earlier this week: creating a homeless day center, opening public restrooms, installing more benches and enacting a sidewalk-obstruction law that doesn't require a tape measure for street cops to enforce" (Rose, 2006b). The types of services included in the conversation mirrored exactly the services identified by the SAFE committee report and are generally services that can make living on the streets less difficult, but do little to address the structural causes of homelessness. This list of services developed during the SAFE committee process appears in most of the descriptions of the ordinance during this time period, pointing to it as a major source of narrative and framing of the time. The influence of this community agreement on the policy course can't be understated; it set the course for the conversation and was referenced widely at the time.

The connection to services allows city leaders to say that they're balancing the needs of everyone. "We can all feel proud that we live in a city that not only addresses its problems head-on," the mayor said, "but also does it in a way that is humane" (Rose, 2006b). It also allows the supporters, in this case the Portland Business Alliance (PBA), to focus on their support of the services as well. Much of the coverage of the time highlights the amount of money donated for these services, for example another quote from an article earlier that week frames the effort as financially supported by both the city and the PBA, "Earlier this month, Potter convinced the rest of the City Council to allocate $\$ 750,000$ from a budget surplus to the new initiative. Of that, $\$ 45,000$, plus 
$\$ 45,000$ from the Portland Business Alliance, would go to nonprofit groups and possibly churches to start temporary day shelters by mid-January.” (Rose, 2006a).

The support by homeless service providers of the SAFE initiative's focus on blending of services with the sit-lie prohibitions by also gave credibility to this approach. For a while at lease, there was a narrative that everyone agreed with this approach, including those representing the homeless. In an interview, a city official stated, "You know the fact that regardless of where you fit on other issues, both parties want to see safe areas and a safe community. Not only for the businesses but the people experiencing homelessness, and the services are trying to provide outreach and resources to them and everybody kind of wants the same goal" (personal interview). This is an example of what I call the "Portland response;" a way of doing policy that emphasizes the need to work together and find areas of agreement, or consensus, or dialogue. This framing focuses on policy not being a power play of who wins an argument, but a negotiation of coming to a consensus solution.

By focusing on coming to an agreement supporters could turn the focus away from the "winner" and "loser" framing that comes out when targeting homeless, and focus it away from homeless to community expectations for everyone. For example, during an interview one city official said "I think a piece that is missing though is that, in taking away the argument of whether or not it is targeting individuals or not is the point that people are asking that what are you having as community expectations? In other words, if what you have is illegal behavior, and it isn't good for the overall community, 
does it really matter if the individual committing the behavior is in a three-piece suit or homeless?" This focus away from homelessness to what is good for a "larger community" is part of this "Portland response" that policy should be about everyone and agreed upon by everyone through a public process. However at the same time it removes focus on a potentially vulnerable population that is affected more than others. It also seeks to re-frame the debate to a conversation about behavior rather than economic status. This framing occurs repeatedly through 2006 and early 2007 by both government and business interests, with little public opposition. This all changes in mid- 2007.

\section{8-2009 Fragile Balance Falls Apart}

During this time period from 2008-2009, the fragile balance built during the citizen stakeholder committee work fell apart. The main homeless advocacy group Sisters of the Road pulled out and the business community may have had a hard time keeping their extended constituency on board as well. There were multiple protests in front of city hall around sit/lie and anti-camping ordinances as Sisters of the Road began actively advocating against the law and calling for the provision of services that had been promised in the SAFE committee agreement prior to the enforcement of the sidewalk regulation component. Enforcement of the law began, nonetheless, sparking another legal challenge. This law was also declared unconstitutional and enforcement shifted to focusing on ticketing for rather minor offenses for laws that were already on the books against behaviors such as spitting, littering, and loitering. 
While this study stops at this point in the sit/lie ordinance process in Portland, in recent times the new mayor and new council continued to take up the issue, as the Portland Business Alliance kept asking for solutions. Commissioner Fritz hosted some town hall meetings, and the new mayor began using a bureaucratic process to reinstate pedestrian through zones, which are currently being expanded through department of transportation bureaucratic changes pushed by the mayor.

In the homeless community, it is well known that the city begins to disrupt homeless encampments under central city bridges and in parks as the summer festival and tourist season begins. Following one of these first displacements of the season in early May 2008, an impromptu homeless protest began in front of city hall. This very visible protest in which dozens of people moved their camps to the sidewalk in front of city hall raised the issue of displacement of the homeless in the public eye. The demands were focused primarily around the need to lift the ban on camping in parks, but also touched on the sit/lie ordinances. Shortly after the protest, the main homeless advocacy group withdrew from the SAFE committee and actively began protesting against sit/lie.

This protest movement came to the fore almost one year after, in August 2007, the city council voted to begin enforcement despite the full suite of services proposed in the SAFE report that were not yet implemented. The enforcement of laws without services demonstrated that the negotiated agreement which included an agreement to support a new law in exchange for social services was untenable. This strategy may have brought many stakeholders to the table, but eventually this fragile balance came apart because 
while there are legal and systematic structures for enforcing laws, the "handshake" agreements of stakeholder recommendations have no built-in accountability.

The accountability of the stakeholder processes rely on public perception and a political will to follow through with the designed solution. The three different types of homeless organizations responded differently, based on their mission and approach. In this case, since this did not happen, one of the key stakeholders withdrew their support and drew on their advocacy roots to turn to protest. Another key stakeholder began to focus more on the need to form a stakeholder community review of enforcement actions to try and reduce the harm caused by the law. Legal organizations took the law back to court.

In 2009 the ordinance was again declared unconstitutional, with the Multnomah County Circuit Court finding that it "conflicts with the state's disorderly conduct law" (Aimee Green, 2009). Shortly thereafter, the police stopped enforcing sit/lie and began increasing enforcement of other things such as littering.

\section{Conclusions}

This chapter highlights two main findings, 1) that the types of non-profit organizations present and their missions and approaches structure the ways they resist laws and 2) the policy arenas also structure the debate. The mission of the organizations influences what actions they can and do take. Three major advocacy groups were involved and they each took different approaches. Sisters of the Road took an advocacy 
approach by organizing and participating in a citizen committee (but eventually withdrawing). JOIN took a policy ad protests advocacy approach by watching policymaking and pushing back; they also participated in a citizen committee. By focusing on policy implications such as enforcement and oversight JOIN also continued to keep the issue in the public eye and in a policy debate. Legal groups focused on rights through the court system and used the law to get the court system to strike down policies. This approach of working through the courts rather than local government had a two-fold effect: first, it caused specific laws to be thrown out and influenced how subsequent laws could be shaped and second, provided a different narrative of rights and legality that the other resisters could use to their advantage while working to influence local government policymaking.

The arenas also influence policy-making. Initial changes were tried by the city under administrative changes that would not require or usually solicit community input. But activists were able to step in and change that conversation to include public comment and turn it into a public issue, not a bureaucratic one. Due to the context and history I call the "Portland response" the policy-making shifted to a stakeholder citizens committee. That approach does rely though on elected officials that see value in public debate, and choose that option. More recent administrations have pushed it back to a bureaucratic venue. That approach also has mixed results.

The collaborative stakeholder process changed how different groups saw the issue, and transformed the conflict to some degree. When the advocates can articulate the 
other's ideas and show points of agreement and clear points of differences that is an indication that they really did work together. Negotiation theory would say that was a successful element of the negotiation. The negotiations narrowed the realm of conflict, but also required people to change their positions on the issue. The question is still whether the negotiated agreement is indeed better for all sides, or whether the groups with more power get more benefits. Compare the stance of the legal advocate's in Portland that some limitations are totally reasonable to the Sisters of the Road advocates assessment that they would not want to sign off on something, and the stance we will see in the following chapter of the San Francisco advocates that any law is totally negative and racist and classist. Moving away from polar opposites is good for coming to a negotiated solution, but is a negotiated solution the appropriate way to protect or articulate rights? We will turn next to the San Francisco case, where resisters have taken a different approach. 


\section{Chapter 6 - San Francisco Case}

In 2010 voters in San Francisco passed an ordinance making it illegal to sit or lie on the sidewalks anywhere in the city from 7a.m. to 11p.m., with a few exceptions for things like medical emergencies and certain protest actions. Enforcement of the ordinance began in April 2011 following a lengthy discussion of how best to implement the required systems for giving a warning prior to issuing a ticket.

This new law was noteworthy, in part, because it appears to be the first time an electorate in this country's passed a sit/lie ordinance through an election, resulting in different dynamics of the public debate compared to other cities that passed similar laws through a city council-led process. The ordinance is also significant because it applies to an entire city. Sit/lie ordinances in most other cities focus only on a specific geography in the downtown area, so a homeless person could leave the restricted area and sit on the sidewalks in other parts of town. In San Francisco, residents have to leave town entirely. For people who are homeless and who have no private spaces to use, this seems to criminalize their very existence. San Francisco is an important case to analyze because its restrictive sit/lie ordinance was passed in a historically progressive city with a wellestablished progressive grassroots community.

San Francisco's progressive activism often has focused on the goal of a more socially just city. The city is in the center of a new explosion in the technology economy and related capital investments, and maintains its role as a center of global banking and finance. Although it is easy to dismiss the sit/lie ordinances as something that 
conservative communities do, it clearly can happen even in a place like San Francisco. What follows is an analysis of why and how this ordinance was passed in one of the most socially progressive cities in the United States. This chapter highlights key moments in the policy process, with special emphasis on how the policy structures and communicative actions interact and change over time. The venues for political debate shape the types of actions supporters and resisters take. The supporters and resisters actions also influence each other's potential actions.

\section{Origin Story and Historical Context}

How did the idea of a sit/lie ordinance become an active, public issue in San Francisco? There are many origin stories circulating; the dominant story is that local merchants and restaurants in the Haight--Ashbury neighborhood organized after being fed up with inappropriate behavior by the many young people living on the streets near Golden Gate Park. The exact origins of the ordinance are still unknown; however, there is evidence that Mayor Newsom (Mayor from 2004-2011) had been exploring the option three years before the merchants association started talking about the issue. The discussions did not begin in earnest until early 2010 when Newsom brought an ordinance to the city's board of supervisors.

While the particular version of sit/lie that I am examining first came to into the public narrative around 2010 these issues have been periodic and episodic for several decades. For example, there is an often-repeated narrative in the activist community that in the 1970s a version of a sidewalk regulation ordinance was used to remove visibly gay 
men from sidewalks outside of gay bathhouses and bars in the Castro district and gay rights activism against this practice. While the examination of the accuracy and historical details of that narrative is outside the scope of this project, the story informs the analysis and strategies of activists today, as we will see later.

There is also some evidence that laws regulating sidewalk usage had been in operation in San Francisco in the late 1980s and early 1990s. In 1992 the San Francisco Police Commission banned the use of a sidewalk obstruction law to conduct "street sweeps" of "beggars and the homeless" (Pimsleur, 1992). At about that time, thenmayor Frank Jordan implemented the controversial Matrix program, which was widely cited as increasing policing against homeless people. The following year (1993), Mayor Jordan introduced a ballot measure (Proposition M) that would make it illegal to sit or lie on sidewalks during the day in business districts, sparking protests from the Religious Witness with Homeless People and other organizations (Sandalow, 1993). Prop M of the early 1990s was rejected by voters. At about this same time, other smaller municipalities in California and notably Seattle, Washington were passing their first sit/lie laws.

After the defeat of Proposition M in 1994 and the reversal of the Matrix program following another mayoral election in 1996, the issue dropped out of public discourse for nearly a decade. During this period, a number of smaller municipalities across the United States, especially small suburban communities in California, passed sit/lie laws. After this first wave of laws, there was about a ten-year gap when sit/lie laws were no longer 
being debated in cities. This changed in 2006 when Portland, Oregon began debating an ordinance. San Francisco took up the issue again soon thereafter.

Between 2007 and 2011 there was increased activity towards a sit/lie ordinance in San Francisco. The policy process that took place during this time is of central interest for this analysis. The process roughly follows the well-established phases that are cited in policy analysis literature: agenda setting, policy formation, and decision making. The complexities of these activities are what is of interest here, and these activities are broken down further, paying special attention to the ways in which actors shaped communicative discourse around the issue in each of the phases of the policy process. It is this communicative work that makes the policy as it progresses through each of the phases. The phases are also not strictly linear, with discursive activities pushing policy making back and forth along the continuum over time.

\section{The Actors}

While there were many actors influencing public debate, and a range of opinions of the measure, there are some key players and positions, roughly grouped into the supporters group who wanted a sit/lie ordinance, and the resisters who were against the law.

The supporters coalesced into one central advocacy group that formed a campaign organization calling themselves "Civil Sidewalks," and officially registered as "Yes on L," the name of the proposition to ban sitting or lying on sidewalks. The group's 
membership included some merchants from the Haight--Ashbury neighborhood commercial district as well as other neighborhood business districts. These merchants were largely owners of smaller, local businesses that served residents and tourists. Many local residents and businesses did support the campaign and were the public faces of the group. However, records suggest that the official organization was largely run by professional political consultants and funded by venture capitalists. As an officially registered campaign group, their public fundraising records show that others were also key leaders of this campaign organization. Of the three identified officials, two were professional campaign consultants and one was the owner of a small business on Haight Street. Funding documents show that the largest contributors to this campaign were the "Committee on Jobs," a lobbying group of the largest employers in San Francisco (including Gap and Wells Fargo), and a number of venture capitalists currently or formerly involved with Google, PayPal, and other high tech investments. The Yes on L campaign raised close to $\$ 400,000$, for which it spent money on media advertising, campaign materials, and professional services to influence voters.

The resisters organized into a group calling itself "Sidewalks for People" and was comprised of progressive neighborhood, labor, queer, and homeless organizations. They received endorsements from over 50 organizations, but raised much less money and instead used traditional grassroots organizing strategies to influence public opinion. They, and other groups, influenced voters through sponsored events like lemonade stands, rogue advertising, and neighborhood canvassing. 


\section{Early in the Process}

In 2005 Gavin Newsom was elected as mayor. He campaigned partly on his platform of Care Not Cash, another controversial homeless strategy that would reduce cash payments to individuals and instead channel resources to community agencies to provide services. This campaign brought new political attention to the issue of homelessness, and especially the issue of chronic, visible homelessness in public spaces. In 2007 Mayor Gavin Newsom started talking publicly about the need for a sit/lie type ordinance to regulate sidewalk behaviors. That same year a delegation from Portland came to San Francisco to share their experiences with creating their Street Access For Everybody (SAFE) committee to create a sit/lie law. And indeed the city did originally take this similar path by beginning to convene stakeholders to discuss the issue (personal interview with advocacy organization).

The district attorney's office called homeless advocates and service providers together to begin a community discussion about an ordinance. The advocacy organization began working with the district attorney's office, but the effort was short lived; the district attorney's office was instructed to end talks with community members (personal interview with advocacy organization). Had the city proceeded with this approach, the policy process may have looked more like the one followed in Portland and described in previous chapters, with representatives of citizen groups coming together in a multiple stakeholder policy process. Following this short-lived potential stakeholder process with only previously identified participants, there was a period of relative silence 
on the issue from city officials. While it cannot be confirmed, it is reasonable to guess that this was a period of closed-door analysis and planning as the Mayor's office prepared to engage in a different policy process.

In December 2009 the issue quickly became much more public as it moved from the realm of city hall conversations and into public newspaper coverage. San Francisco Chronicle columnist CW Nevius started writing about the need for a sit/lie ordinance in the Haight -Ashbury district. This marks a period when the issue became part of the public conversation, and these early articles spurred action by resisters and supporters. Over the next several months people gathered on both sides of the issue and the public debate grew larger.

\section{Setting the Stage: Thugs}

The earliest articles by Nevius argue that the ordinance is needed to control the "thugs" who engage in criminal activities in the Haight - Ashbury district. In one of the first articles he writes in March of 2010, "Police Chief George Gascón has been pushing for a sit/lie ordinance in the Haight after learning of bands of thugs blocking sidewalks and bullying merchants, pedestrians and neighborhood residents" (Knight, 2010). This is the time period when actors first frame an issue as important enough for public talk and action. In it, actors define what the problem is, who the ordinance should target, and how the problem should be solved. It is also important because the language that initially frames the debate can set the tone for the ongoing discussion. 
In a number of articles, Nevius argues that the ordinance is needed to control the "thugs" who engage in criminal activities in the Haight - Ashbury district, or as another commentator describes, "The people who have ruined the ambiance of the street are the violent thugs who've moved in....who've made it a frightening exercise to simply walk down the street -- that's what we're trying to control" (Knight \& Cote, 2010). The thugs are dangerous, but also described as "human garbage", serving to further marginalize the people being targeted by the ordinance: "That neighborhood is paying the price of its over-the-top liberality and tolerance of bums and thugs. This moral vacuum that is part of the hippies' legacy has sadly allowed human garbage to reign in that neighborhood" (Nevius, 2009).

The imagery of the targets of the ordinance as dangerous also relies on contrasting them with others who are members of protected classes. For example, note the separation of the thugs as a sub-population of other homeless: "This issue is not about San Francisco's homeless citizens, it is about law-abiding, tax-paying San Franciscans being held hostage by transients wielding deadly animals as weapons." (The San Francisco Chronicle, 2010a). With this theme, the "transients" and "thugs" are framed as dangerous and sub human, and separate from those who may be worthy of protection. In this we can see an appeal to a bit of the progressive San Francisco liberalism in which the homeless are often seen as a group that is worthy of pity or support. The quotation may imply that most homeless people are closer to the group of non-homeless "citizens" that deserve protection, but that the targets of this ordinance are so dangerous they have 
“deadly weapons". The deadly animals comment references the pet dogs that are common to young people living on the streets in the Haight--Ashbury neighborhood. It should be noted that while there are several documented cases of dog bites, there are no documented cases of death by any dogs during this time period.

There is also a marked theme of wanting to distance the targets who are viewed as different from previous homeless, Nevius writes: "Sleepy stoner panhandlers have given way to aggressive street punks who stand in the path of pedestrians and demand payment" (Nevius, 2009). With this framing, it is not the deserving, harmless homeless who had been in the neighborhood for years who are causing a problem in this frame, but rather the undeserving subset from outside and recently being in the neighborhood that require regulation. This framing not only frames the targets as aggressive and undeserving, but also serves to try to give urgency to a new problem to be solved.

As these quotations show, the problem is bands of bullying, violent thugs who scare everyday residents. It is unclear if the police have existing laws or tools to manage the incidents described, but Nevius later indicates that the "Police said they didn't have the tools to move intimidating thugs from in front of businesses, and everyday citizens came forward to say that they felt fearful walking the streets" (Nevius, 2010b). From his writings, we can see the argument that the ordinance is intended to target those who are committing crimes and making the city unsafe for small business owners and local residents. This creates a clear line between people who deserve to use the space (merchants and residents) who are defined as "everyday citizens," "homeless citizens", 
and "law-abiding, tax-paying San Franciscans" and people who don't because they're new to the place ("thugs who've moved in" and "transients", "bands of thugs" and "aggressive street punks" who are violent). When the problem is framed this way through the discourse, it is easy for supporters to argue that a solution could be increased tools for police to rid the place of these deviant outsiders.

\section{Politicization and Early Mobilization}

These early newspaper opinion articles from 2009 and 2010 set the stage for a discussion about sit/lie as a potential policy priority, and set a particular discursive tone and set of frames with which to talk about the issues. The tone of these early articles ended up politicizing a wider group of progressives, drawing their attention and mobilization to the issue. Interviews with several key resistance organizers identify Nevius's articles as being the thing that drew their attention to the issue, and for framing initial conversations about the policy debate. It was these portrayals that they felt were particularly de-humanizing and punitive that drew them into the debate.

At the same time, Mayor Newsom also stepped into the public conversation, coming out in favor of an ordinance. The story which is often repeated in the newspaper coverage of the time is that in early 2010 he first saw the need for an ordinance after walking with his young children down Haight Street and being shocked to see the drug use there (Nevius, 2010a). The evidence suggests that this was actually a policy issue that his office, the district attorney's office, and the police chief's office were all considering prior to this event as earlier newspaper articles already cited here show. 
Newsom lived a few blocks up the hill from Haight Street at the time, so was probably aware of a historical and current drug (marijuana) culture around the Haight-Ashbury district. The month after this publicized walk down the street, Newsom introduced two versions of sit/lie to the San Francisco Board of Supervisors. One version included a prohibition against sitting or lying on sidewalks across the whole city, and the other in just select business districts. He would eventually settle on the version covering the whole city.

The introduction of an ordinance to the Board of Supervisors provided another public forum for debate on the issue. This particular policy-making avenue has a very clear and proscribed process for public comment that includes both public meetings in main and committee sessions, as well as conversations with and among individual elected representatives. At this point, the wider range of resisters who had been politicized by earlier newspaper coverage now had a venue in which to influence decision making.

The key resisters felt they needed to put pressure on the progressive members of the Board of Supervisors to get them to vote to defeat the measure (interview, public space advocate). One activist reported in my interview that he felt the progressive community needed to make it clear to progressive elected officials that being progressive, and being supported by the progressive community, meant voting no on ordinances instituting sit/lie.

In order to show the elected Board of Supervisors (a majority of which were progressive) the support of the community against the ordinance, a pair of progressive 
advocates who work on a variety of issues around town planned an awareness-raising event to try to influence those votes. One of the advocates who had an interest in public space movements decided to model an event after parking day events where groups of individuals take over parking spots for a day to try to reclaim them as public space for other uses. Using this model, he called for a day of action to re-establish the use of sidewalks for people to use for everyday life. People across the city set up barbeques and parties, held readings and meditation sessions, and other events (personal interview with public space activist).

One of the purposes of the event was to make the point that public spaces are for resting, relaxing, and enjoyment and that public spaces are important for building community:

Nearly 100 events across the city. More than 1000 people participated. Hot tub parties or on the sidewalks. Sidewalk sales. Lemonade stands. Yoga. Beanbag tosses. People doing poetry. People playing music. It demonstrated how powerful our public spaces can be in bringing community together when we open them up for our community, we give up public space used to interacting get to know one another, the space that we need to create communities. There are social reasons why folks need a place to sit and need a place to be. (Interview with Public Space Activist). 
The sidewalk event is an example of a right-to-the-city narrative. Resisters make the case that public spaces are important for community; they're social spaces. And people who can't afford to buy into places like cafes or bars for a sense of community need the sidewalks to have a sense of community. Of course, there are other narratives that have been used by resisters to sit/lie ordinances: the right for the homeless not to be discriminated against, and the right to use spaces for other than exchange value.

This issue about what types of activities are acceptable to engage in on the sidewalks raised a point of contention between the two sides. The resisters were making the argument that for people living in cities, sidewalks have many uses that are vital to communities but that would be illegal under this ordinance. When the supporters made the argument that they wouldn't be targeting lemonade stands run by kids, the resisters pointed out that this intentional selectivity of whom it would be enforced against was discrimination based on class. This is a rights-based argument. Resisters are making the argument that these laws are restricting poor people's rights to use the space, for example:

They [supporters] promise not to bother tourists taking a break from shopping or day laborers, and that sounds like selective enforcement. How do we decide who does get targeted? That is by profiling on appearance or based on who the police or business association decides are unwanted populations. They have no rights. There is no justice if you are poor (Interview with homeless advocate). 
This interviewee above pointed out that upscale use of the sidewalks was acceptable but public use of sidewalks was not, they continued: "It's ok to have your cafe seating, it's ok to have your things deemed vibrant which means for folks for higher income, but it's not ok for the folks to use it for public space." Vibrancy is a common goal identified by planners as a positive feature of public space in cities. By using the language of planners, the organizer is referencing the public good praised by official government policy of having people use public spaces. At the same time however, she is naming a distinction that she sees in official policy, but that that is outside of the official narrative: that public space is to be used by people with higher incomes, rather than the visibly poor.

The Sidewalks are For People event used this turn of narrative in order to humanize the activities that happened on the sidewalk, and to re-frame the conversation about who can use public space for which purposes. The intent of the day-of-action sidewalk event was to highlight the "ridiculous nature" of the ordinance. From the activist perspective, this ordinance was counter to the other public policy priorities of the city that were intended to encourage the use of public spaces and to cultivate public community events in public space (interview with public space advocate). By highlighting the fun events that the ordinance would technically make illegal by regulating sitting, the activists were also highlighting the selective nature of enforcement. They were making the case that the law really wasn't about regulating sitting on the sidewalk but was about regulating homelessness. 
In addition to the day-of-action events, resisters also organized a protest event on the steps of city hall the month that the vote at the Board of Supervisors was expected. Other early activism included going to a hearing held by a city subcommittee that was organized to investigate the sit/lie ordinance. Resistance advocates attended this meeting and provided six hours of testimony against the ordinance.

The activists' perspective is that they were successful with their events because they demonstrated to the progressive representatives that to be progressive in San Francisco meant you had to be against the sit/lie ordinance:

And it [the sidewalks event] just made it very clear that if you wanted to be considered a progressive in San Francisco you were going to have to go against sit lie. So it definitely shifted it at the board, cause the folks who were fighting it before I got on board were counting the votes, and they didn't have them. It was like this is going to get past the board. But we definitely had the votes after that, you know. (Personal interview, public space advocate)

By June the Board of Supervisors did indeed vote down the ordinance, with only the three moderate representatives voting for it. Less than two weeks later, Newsom filed the paperwork to put the ordinance on the ballot and open it up to a vote of citizens. Activists now had to change their strategy. Originally, their efforts were intended to influence the votes at the Board of Supervisors. When it became an issue that the electorate would decide on, their strategy had to change as well. 


\section{A Useful Tool or a Discriminatory Law?}

At this point, there are two main and competing narratives in the public arena. As described in detail above, the narrative advanced by supporters is that aggressive thugs are dangerous and need to be controlled. The narrative advanced by resisters is that sidewalks are for people to use, and progressive San Franciscans should not tolerate laws that could be selectively enforced against homeless people. This debate continued during the run up to the election, but also began to shift slightly.

One of the significant debates stemming from this framing was whether the law was, as the advocates had framed it, a tool to help the police control dangerous people. The resisters called it a discriminatory law. As we saw earlier, the framing of the supporters relied on arguing that the targets of the ordinance were a dangerous group of people who were best controlled through regulation. Since there are already many laws regulating the kinds of aggressive behavior that they were concerned about, they had to make the case for a new law. In order to make this case, they focused on the role of helping the police do a difficult job, "Supporters, including Mayor Gavin Newsom and Police Chief George Gascón, said a sit/lie ban would give police officers another tool to move along thugs who block sidewalks and intimidate passers-by" (Knight, 2010d).

Here we can see that it is the aggression that the law is targeting, and the goal is to give police a much needed tool to address crime/aggression. They were making the argument that they need tools to target criminals. The above quotation shows that the goal is to help police officers, and it re-enforces the bad behavior of "thugs" who 
intimidate people. In Ingram and Schneider's $(1993,2007)$ topology of frames, police are considered an advantaged group that deserves help from the public. This is the framing of police that supporters were trying to tap into.

To counter, resisters argued that the law will become discriminatory. In particular, the public defender was very vocal in voicing this concern. In trying to influence decision makers, he brought up issues of abuse of power by police, saying, for example, "Delusional fantasy aside, the fact is we live in a society deep in a drug war, and racial profiling is a reality. As a public defender, I have read hundreds of police reports in which invasions of privacy are justified by the pettiest excuses for police action, including jaywalking and blocking sidewalks" (The San Francisco Chronicle, 2010b).

Many San Francisco resisters also focused on discrimination. Homeless advocates quoted in the San Francisco Chronicle focused on the discriminatory act of selective enforcement, "Friedenbach [director of the homeless coalition] said she has no doubt police will use the law judiciously --and that's the problem. 'It'll be enforced selectively, which is not appropriate,' she said. 'Then you're getting into a huge constitutional problem. Laws are not meant to be applied to specific groups according to their status'" (Knight, 2010b).

Some resisters focused more specifically on the widespread belief among resisters that the law was intended to be used to cite people of a certain status or appearance. Here is an example: "Or maybe those who are responsible for the language of the legislation to 
(ibid) change tack so that it reflects what is really going on here, which is maybe putting forward a law that makes it illegal to be a thug or a drug user or a freak or homeless or maybe a law to make it illegal to be a youth or dog owner or a kid in San Francisco, and then see where the voters stand on that one, and I think you will find that people will resoundingly oppose such an anti-people proposition" (SF Public safety committee transcript, 2010).

While the pro-sit/lie camp specifically framed the targets of the ordinance as criminal thugs, and that the ordinance was needed to help the police, resisters attempted to change the narrative to demonstrate that the actual targets were "the poor" or "the homeless" who would be discriminated against by the police using that tool. Resisters were concerned that the law would be selectively enforced and serve to criminalize those who are homeless. This framing of "the poor" suggests a vulnerability or dependency that allows resisters to make the case that such a law would be harmful. This vulnerability suggests the need to protect, and in this case the need to protect their rights. This is in stark contrast to a framing of aggressive law breakers that deserve criminalization.

\section{Election Time}

The defeat of the initial ordinance at the Board of Supervisors and Mayor Newsom's decision to put the issue on the ballot introduced a new venue and set of structures for participation in the policy process. Supporters and resisters both needed to 
shift their audience: they no longer had to convince the Board of Supervisors which way to vote, they now had to convince the entire voting public of San Francisco.

This also presented another potential opportunity. Since California has a mechanism to allow for voters to put referendums on the ballot, the resisters could have put another measure on the ballot for consideration as well. Indeed, they initially had considered the possibility of putting a less restrictive counter measure on the ballot in San Francisco (personal interview activist organization). The activists chose not to do that saying that any form of mild support, or support for a less restrictive ordinance, would open the door to criminalizing people and they were going to take a firm stand against it.

They made the decision to fight the ordinance, now called Proposition L. They formed a wide coalition of progressive groups across the city to work together, which is when they organized into a group calling itself "Sidewalks for People" which was comprised of progressive neighborhood, labor, queer and homeless organizations. They received endorsements from over 50 organizations, but raised much less money and instead used traditional grassroots organizing strategies to influence public opinion. They, and other groups, sponsored events like lemonade stands, rogue advertising, and neighborhood canvassing to try to influence voters. They wanted to pull together a wide variety of mission based organizations due to the history with LBGTQ communities having experienced discrimination and regulation of their use of public space. They also especially wanted to organize around the issue in the Castro (the historically gay community) in order to mobilize progressives in that particular neighborhood. The 
contested election for district supervisor in that neighborhood was one of the elections that moderates needed to win in order to shift the balance of power on the board of supervisors. The resisters claimed that the supporters were using sit/lie as a wedge issue to bring out moderates in this community, so they countered with bringing out progressives. This wedge issue is discussed in depth later in this chapter.

\section{An “Astroturf” Campaign}

With the electorate voting on the sit/lie ordinance, the stakes were high. This was no longer an issue to be decided by the Board and those interested specifically in this issue. It would be a public issue for all citizens to weigh in on. The activists in San Francisco assessed the supporters of sit/lie as being interested in maintaining property values in the neighborhood. This assessment rarely makes it into the newspaper coverage, which largely continued to talk about the needs of neighborhood businesses, but greatly influenced the resisters and their actions.

The needs of neighborhood businesses when they appeared in newspaper coverage were described in general terms, and framed merchants as the beneficiaries of the ordinance. For example, in one article the Chronicle writes, "Mayor Gavin Newsom is pushing a workable and fair answer to merchant and citizen complaints about vagrants sprawled on sidewalks and intimidating passersby..." (The San Francisco Chronicle, 2010b). The language here focuses on how the mayor is supporting a protected group of people the, "merchant and citizen" and ascribes the origin of the policy approach to their complaints. This quote also demonstrates the focus on such an approach being "workable 
and fair," pushing back against the claims that the ordinance would unfairly target a group of people based on their economic status.

While this narrative appears in newspapers, there is another interpretation that doesn't appear in the newspaper record, but did appear during interviews with resisters. In interviews, there was a very prevalent sense in the organizer community that the politicians and their campaign consultants first had a policy approach in mind, and then went to the small businesses on Haight Street to get them involved (multiple personal interviews with homeless and public space advocates). Organizers call this an "Astroturf" campaign, meaning something that is made to look "grassroots" but is instead "fake" and manufactured to look like the real thing.

The lead merchant most often cited in newspapers refused to talk with me about the issue, saying he doesn't do interviews on the topic anymore. Others who were contacted for this research mentioned he might be hard to reach for the same reason, and suggested that he may have been burned being the public face of a contentious campaign, especially in the historically progressive neighborhood. One neighborhood representative working in favor of the sit/lie ordinance tells a different story. He argues that he and his organization brought the issue to the local police station and began engaging the police department and asking for help controlling aggressive behavior in the neighborhood. This representative suggests he did research on various sit/lie ordinance languages from other cities and brought them forward to the district attorney's office (personal interview with supporter of sit/lie). While the District Attorney's office never replied to any 
requests for interviews, the other findings of this research as already described call this narrative into question, noting the role of elected officials downtown very early on in the policy process. Instead, this unlikely narrative of the idea coming from neighborhood leaders does support the "astroturf” analysis of resisters.

Despite these different narratives on the role of local merchants in the origin of sit/lie, it is clear that local merchants played some role in discussing and advancing the issue in the public conversation. They were interviewed in many newspaper articles and had community meetings to discuss the issue. And not all of them were quoted as being in support, for example in this quote published in the newspaper from a prominent local merchant argues that the homeless population was not a problem for their store:

For Praveen Madan, co-owner of the Booksmith on Haight Street, the street kids who congregate in the famous neighborhood are merely an inconvenience. Occasionally, they block the entrance to his store or intimidate customers, but politely asking them to move on usually does the trick. "It's a myth that's been propagated that there are gangs of thugs taking over our streets," Madan said. "Criminalizing them and putting them in jail hardly seems like the answer." (Knight, 2010c).

The one supporter that did participate in interviews lacked knowledge about the details of the "Yes on L" campaign in particular, suggesting that the campaign was largely run by professional campaign staff. The "Yes on L" campaign's main 
expenditures as reported through public records were hiring professional campaign consultants and purchasing mainstream media television ads.

It is clear from campaign finance records that the biggest financial supporters of the "Yes on L" campaign were from the technology, finance, and other elite sectors. Funding documents show that the largest contributors to this campaign were the "Committee on Jobs," a lobbying group of the largest employers in San Francisco (including Gap, Wells Fargo). Other contributors included Ron Conway, a venture capitalist and early Google and Paypal investor (who continues to be active in funding moderate candidates and campaigns in the city); several other venture capitalists; financial services company namesake Charles Schwab (who donated $\$ 15,000$ ); the president of the 49er's; and a well- known president of the de Young Museum (Campaign Disclosure Statements 2010). These are the typical "growth machine" actors. While many were heads of very large global corporations, and certainly very wealthy, they were also local residents with ties to the local political elite structure. As I will discuss in future chapters, it seems to be those local connections that are more important here than their connections to global capital.

The Yes on L campaign raised close to $\$ 400,000$, for which it spent money on media advertising buys, campaign materials and professional services to influence voters. Many local residents and businesses did support the campaign and were the public faces of the group. However, records suggest that the official organization was largely run by professional political consultants and funded by venture capitalists. 
The supporters coalesced into one main advocacy group and formed a campaign organization called "Civil Sidewalks." The group's membership included merchants from the Haight -- Ashbury as well as other neighborhood business districts. These merchants were largely owners of smaller, local businesses that served residents and tourists. As an officially registered campaign group, their fundraising records are public. These records show that of the three identified officials, two were professional campaign consultants and one was the owner of a small business on Haight Street (campaign disclosure statements, 2010). That business owner declined to be interviewed for this study, saying he is no longer discussing the issue.

The "No on L" campaign raised much less, just under $\$ 11,000$. Donations of largely less than $\$ 500$ each came from individuals such as nonprofit workers, teachers, nurses, and organizers themselves (Campaign Disclosure Statements, 2010). This disparity in financial resources shaped the strategies used by each side.

The "Yes on L" campaign spent most of their money on paying for a professional lobby firm that purchased advertising and provided big media buys to reach a large swath of voters. Advertising does seem to be a big issue in this case. One common belief among the resisters interviewed for this research is that the "Yes on L" campaign won largely because the giants went to the World Series that year (personal interviews). The "Yes on L" campaign was able to run television spots during the highly watched playoff games where the San Francisco Giants baseball team won their division and a spot in the World Series. 
In contrast, the activists resisting the sit/lie ordinance chose to run a campaign that was a mixture of door-to-door outreach, flyer drops, and coalition building among progressive community organizations. One main take-away about this strategy is that the city is too big to do an effective door-knocking campaign, but they didn't have money for big advertisements, so they focused on a grassroots campaign of people-to-people discussions.

The resisters organized another day of protest with their supporters opening lemonade stands all over town. This symbol of the lemonade stand is an innocent activity that instills an entrepreneurial spirit in young people across the United States; it was chosen as a representation of the innocence of most sidewalk sitting and highlighted what San Franciscans could lose if they regulated sidewalk use. This lemonade stand protest again highlighted the selective enforcement issue, in a way similar to the Sidewalks are for People day of action.

\section{Creating a Wedge}

But why is sidewalk sitting such an important issue that political players will invest so much energy and financial resources into creating a campaign? In interviews multiple activists articulated a very detailed assessment of the decision to go to the voters by Gavin Newsom as a calculated attempt to bring a "wedge issue" into the election. This election was more than a vote on sit/lie; it was a general election and some of the city's Board of Supervisors were also up for election. From the perspectives of the activists, this issue was not really about helping neighborhood merchants attract business in the Haight, 
but instead was about drawing out more moderate voters to the polls in some key areas in order to shift the balance of power on the Board of Supervisors.

According to resister activists, the political establishment was looking for an issue to put on the ballot to bring more moderate voters to the polls in order to elect a more moderate Board of Supervisors. The wedge issue seems to have worked. One of the supervisors who was elected at the time, Scott Weiner, has since successfully campaigned for additional "quality of life" laws and policies, including an effort to ban recycling centers that "drew homeless people" to the neighborhood, and a policy to close parks at night. Both arguably continue to reduce homeless people's use of space.

Scott Weiner is the representative from the district that includes the Castro district, a historic hotbed for gay and lesbian rights and activism. The organizers responded to this "wedge issue" by engaging LGBT communities to come out to the polls as a counter to those more moderates. If they thought others were using it as a wedge issue to bring certain people to the polls, they would try to counter by pulling in their own people to the polls. This assessment of a wedge issue influenced their strategy and decision making. In order to pull in the more progressive voters in the district in which Weiner was running, they adopted the language of gay rights and the historical narrative about the dangers of using laws like this against vulnerable populations. They made the connection to the earlier mentioned historical events in San Francisco where Harvey Milk, a gay rights activist from the Castro, fought against a similar ordinance in the 1970s that was being used to arrest gay men in front of gay bars. 


\section{What Would San Francisco Do?}

A large part of these progressive activist narratives intended to influence the Board of Supervisors and the voting public draws on the idea of what a uniquely "San Francisco" approach to sidewalk policies should look like. This narrative relies on a historical context of political progressivism to make the case that progressives in San Francisco would not support this law because it counters the spirit of the city.

Resisters especially used the framing of the ordinance as discriminatory to make the case that discrimination is not what San Francisco is about. One meta- narrative of San Francisco, and especially of the Haight-Ashbury and Castro districts, is that they are a place of tolerance for people who are different. San Francisco has a reputation as a key center of the counter-cultural revolution of the 1960s and the queer, feminist, environmental, and disability rights movements. The resisters of this law tapped into this larger cultural identity to argue that this discrimination against people who looked different was not what progressive, tolerant San Francisco does. Resisters often harkened to San Francisco as a "beacon of hope," or a city that brings in "people from different areas.” (SF Public safety committee transcript, 2010)

This argument is countered by those who supported the sit/lie ordinance saying they, too, are grassroots locals - they're San Franciscans too. They are making the case that their needs trump any needs for tolerance or progressivism. For example, "It's great to be a 'tolerant' city, but residents and business owners everywhere are questioning why we tolerate aggressive behavior, drugs and gangs." Another supporter is quoted as saying, 
"I am a resident of Cole Valley who is getting tired of the reticence of this city to take on sidewalk bullying, intimidation and unhealthy behavior under the guise of 'tolerance' and 'support'." In these quotations, the narrative is that housed residents and small business owners have more right to say what is allowed than a subgroup that is deemed deviant and out of place.

\section{Sit/Lie Passes}

In November of 2010, the electorate passed Proposition L by popular vote and the sit/lie ordinance became law. While the ordinance did pass, the activists still claim some successes. They cite an opinion poll by the Chamber of Commerce that indicated that $71 \%$ of likely voters were in support of sit/lie in early 2010 . By the end of the year, the ordinance only barely passed, which indicates that progressive activists changed the minds of many voters.

After passage of the law, activists began to target enforcement strategies. By negotiating with the district attorney's office, they were able to delay enforcement for three months while the police department put in place effective strategies for educating people about the new law and providing warnings. Since then, the ordinance has been enforced, but the police department has been unwilling or unable to report statistics on its use. Homeless advocates share anecdotal stories of the ordinance being used to make homeless people "move along" from wherever they are. 
Chapter 7: Cross-Case Comparison and Implications for Theory and Practice

This chapter synthesizes and compares the data and analysis described in the preceding two chapters. First, I review the questions that guided this research. Then, I compare findings from each of the two cases on three domains from the research literature that informed this study: (a) interpretive policy analysis, (b) neoliberalism/right to the city, and (c) social movement framing. For the findings in the interpretive policy domain, I focus on similarities and differences in two interconnected areas: the impacts of policy arenas and policy talk. For social movement theory, I highlight similarities and differences about how collective action framing around homelessness and people experiencing homelessness influence this policy process. For the neoliberalism/right-tothe-city debate, I look at the intersection of actors, political economy, and tactics across the cases. Each of these domains is described individually, and then I summarize with a discussion of how the three are interconnected. I argue that a multidisciplinary approach to understanding these policies is important due to this interconnectedness. Finally, I provide some lessons for practice as well.

\section{Guiding Questions and Approach}

The primary research questions for this study are: Who are the actors and what discourses do they use? How do these influence policy talk and decisions over time? The first research question is broken out into specific questions about the actors and the discourses as follows: 
- Who are the institutional and individual actors advocating that policymaking agendas include sit/lie ordinances? What discursive strategies do they use to frame their positions? Who are the institutional and individual actors contesting these ordinances and what discourses do they use to counter them?

The second research question can be broken out into the following questions about how these decisions influence policy talk and decisions over time:

- How do the tensions between different discursive strategies work to change the course of a policy process? How do actors use different arguments? How do actors use discourses to respond to each other? Which are the most effective discourses at shaping the ordinances? How do local contexts shape both discourses and policy outcomes?

These research questions were designed to look deeply into the who, how, and why sit/ lie ordnances happen in order to achieve a more nuanced explanation of how the tensions between neoliberalism and local right-to-the-city forces come together to communicatively shape local policies. This research brings about an understanding of who the actors are, what actions they take, and how those actions interact to create local policy in a neoliberal context. This is a comparative case study of groups of actors engaging in supporting and resisting sit/lie ordinances in two west coast cities, Portland and San Francisco. Because this is a case study, I used document analysis, in-depth interviewing, and secondary data analysis to explore the actions and discourses by the 
various groups in these two cities, as they occur in their political, social, economic, and cultural context.

The purpose of this research is to describe the messages that shape the agenda setting and policy selection stages of the policy process around the creation of sit/lie ordinances. The results of this study add to the theory about resistance to roll-out neoliberalization and contribute an analysis of activism that will inform grassroots practice. This research will also add to our empirical knowledge of how different actors make claims over rights to the city. In addition to informing right-to-the-city and neoliberal resistance theory, this research also has policy and practice implications. In a policymaking realm of diffuse governance where talk about policies matters, this research can help us understand how private actors influence policymaking through discourse. This research also has the potential to help those resisting sit/lie ordinances to understand more clearly the forces that support sit/lie ordinances and thus develop new strategies for resistance.

\section{Key Comparative Findings}

\section{Interpretive Policy Analysis}

Findings from this comparative case study show that there are variations in the policy processes, and that key elements of the process influence decision making. The details across cases are summarized in Table 6 below. In particular, this section focuses 
on discussing the interconnected role of the arenas in which policy is made, and the tactics used by actors in the process.

Table 5: Policy Arenas and Process Comparison

\begin{tabular}{|c|c|c|}
\hline Process Element & San Francisco & Portland \\
\hline $\begin{array}{l}\text { Date of passage / } \\
\text { Length of policy } \\
\text { process }\end{array}$ & 2010 & Decade from 2003-2013+ \\
\hline Policy arenas & $\begin{array}{l}\text { Mayor-driven ordinance } \\
\text { introduced and } \\
\text { subsequently defeated; } \\
\text { citywide election }\end{array}$ & $\begin{array}{l}\text { Technical-focused administrative } \\
\text { changes; citizen committee; legal } \\
\text { challenges }\end{array}$ \\
\hline $\begin{array}{l}\text { Length of policy } \\
\text { process }\end{array}$ & About one year & $\begin{array}{l}\text { Several ordinances over multiple } \\
\text { years }\end{array}$ \\
\hline Tactics & $\begin{array}{l}\text { Lobbying of public } \\
\text { officials; protests; voter } \\
\text { campaigns }\end{array}$ & $\begin{array}{l}\text { Protests; participation in } \\
\text { community stakeholder group }\end{array}$ \\
\hline
\end{tabular}

Finding 1: Political process provides windows of opportunity and arenas for activities. For this initial finding, the overarching conceptual framework questions were: What happened and when? In what arenas do actions occur? The guiding research 
proposition was based on this statement: The type and length of the policy process influences the types of actions taken and the different policy and message outcomes.

Election cycles create moments of political opportunity in which actors begin influencing people. In both cases, supporters of sit/lie use the political moment of changing elected officials to either begin or re-engage in the policy debate. The different policy arenas (citizen election, committee, council led, litigation, etc.) influence the audience that the actors care about. Additionally, the elected officials have a determining effect on which arenas they use, which in turns structures the opportunities for policy discourse.

\section{Finding 2: The arena influences the depth to which resisters can discuss the} issues with the wider public and decision-makers. The conceptual framework question was "Who were actors trying to influence?" The guiding research proposition was: The type of process used influences who actors are trying to sway, and thus their messaging strategies.

Protests are very visible acts of resistance, but involvement in local decision making (either by influencing the electorate or elected officials) has been more central in the resistance to sit/lie. Resisters have used physical protests in public space as a catalyst to drawing attention to issues when they need wider public involvement to influence decision making. However, resisters have also acted through public and private meetings to influence decision makers directly. 
The arena influences the depth to which resisters can discuss the issues with the wider public. In a community committee process like the Street Access for Everyone (SAFE) committee process in Portland there are many opportunities to engage in sharing perspectives including complexities of the issue because only a small number of people need to be influenced and there are more opportunities for engagement. However, in a vote, there are more people who need to be influenced and less time to do it - so the choice on framing and narrative needs to be one that is easily communicated, but may not get at as much nuance. This is one of the reasons that the right-to-the-city frame may not have been used as much as the literature might suggest. Academics have suggested that the right-to-the-city frame is a useful one for fighting for social justice in cities. While there is evidence that the opposition actors in both cities agree with this analysis, they have found it much harder to use this framing with the general public or elected officials because it takes too much time to explain to those unfamiliar. Instead, they rely more on concepts that may be more familiar like the dependent poor and unequal impact.

\section{Neoliberal / Right-to-the-City Actors in the political economy}

I now turn to looking at the relationship between different actors, their role in the political economy, and how both of these things influence decision making. I found there were two main types of actors in each city; those I'm calling right-to-the-city actors who were resisting sit/lie ordinances and those who I'm calling Neoliberal actors, who were in support (see Table 7). This section will further describe the similarities and differences across this domain, and how these influence decision making. 
Table 6: Actors, by city

\begin{tabular}{|lll|}
\hline Type of Actor & San Francisco & Portland \\
\hline Right-to-the-city actors & Wide range of groups & Homeless service providers and \\
(resisters) & including homeless, & advocates, law/civil rights; strong \\
& queer, law, housing, & connections between local \\
& immigration, civil rights, & officials and service providers. \\
& tenants' rights, youth & \\
& organizations & \\
\hline Neoliberal actors & People who are part of & Traditional growth machine \\
(supporters) & the neoliberal political & actors, local economy, networked \\
& economy & relationships \\
& &
\end{tabular}

Finding 3: Local actors have different positions in the global economy however on the local level their different avenues and strategies of involvement are due to local conditions rather than global ones. This finding suggests room for resisters to use local politics to resist these ordinances, without having to take on the entire global economy.

The conceptual questions that framed this research were: Who were the actors? Who puts the issue on the agenda? The guiding research proposition was as follows: Actors vary depending on the city elite's location in the global political economy and/or 
the development of grassroots organizing sectors. The different actors may use different messages.

The instigators of sit/lie ordinances were local business people. Their position in the global economy of these business groups are of different size and scale. For example, many of the business actors in Portland are smaller local or regional businesses located in the downtown core and working together as part of a formal business association. In San Francisco, the most prevalent actors are from the speculative real estate industry and the tech and venture capital industry. Even though there are differences in industry, the actors are still local residents and representatives of these firms. I found no visible evidence of actors from outside of the local area, even in the San Francisco case, which operates as a more global economy.

The location in the global political economy seems to be less important than the local political decision making context. While the business people who were in support in San Francisco were much wealthier and had more money to spend, they were still local people who live and work in the community. Having more money may have allowed them to encourage elected officials to do an election campaign (which is more expensive), whereas supporters with less money may continue to use direct lobbying of elected officials (as part of the lobbyists' platform and work that they do).

The business supporters in San Francisco were very wealthy venture capitalists (VCs) such as Ron Conway, the Angel Investor supporting companies such as PayPal and Google. The business supporters in Portland were a coalition of local downtown 
businesses. This research began with the assumption that the differences between the two types of people's location in the global economy would be a key explanatory factor in the differences observed in cities. I had expected, based on prior theory, that neoliberal actors would function differently based on whether they are more global or more local elites. However, this does not seem to be the case. Instead the local conditions seem to be more important than the location in the global economy.

This isn't to say there aren't differences between venture capitalists (VC) and local business people. The question though is which differences would influence policy decisions on this topic, and which differences are not important? Why would we think that they are different? They may have different amounts of money, and separate spheres of influence on a national or global scale. However, at the very local level, they have to influence the same types of decision makers, in these cases the local Board of Supervisors/City Council or wider public. Sit/lie isn't made in board rooms at the International Monetary Fund (IMF) or even at a national policy level, so these global connections are mitigated by the local ones. While there is limited evidence because supporters refused requests to talk to this researcher, there was no indication from the document analysis that VC investors were asking for these policies everywhere they fund new start-ups, or talking about the need for wider regulation to support their business. (If we were talking about lifting regulations for Uber or Airbnb, yes. But for sit/lie, not yet.). What became apparent, though, was that individuals who are powerful due to their economic status and political connections are influencing city governments in both cities. 
In this sense, the two groups are no different - one group is just richer/has more financial resources to address the problem through different tactics.

The biggest difference between global and local business owners, however, is the amount of money available for influencing policy. Perhaps because the supporters in San Francisco are very affluent they were able to very quickly switch to waging a voter campaign when they faced opposition, while that policy making arena has never been attempted in Portland - even though there has been a contested policy for a decade. This affluence in San Francisco allowed supporters to buy costly television ads during World Series games when the local team was playing.

The opposition had much less money and had to wage a grassroots effort relying on volunteer power. Indeed, campaign financing reports show the biggest supporters of the sit/ initiative were wealthy venture capitalists, and the much smaller donations for the opposition came from formerly homeless advocates themselves. This disparity in resources made a major difference in strategies and tactics that were available to each side. A voting campaign is very expensive in both time and volunteer hours, and must rely on short messages to get voter attention.

What this demonstrates is that what may be more important is the political context in each city that influences the types of tactics and strategies that can be used. The city of San Francisco tried the citizen committee approach when they first started - but that isn't how things get done there. The resisters used confrontational tactics rather than collaborative ones; they mobilized progressive allies on the board of supervisors who at 
the time were powerful influencers. This showed the mayor's office that a different approach was needed in San Francisco. Not because the supporters were venture capitalists, but because the resisters were going to use different tactics and the political climate/structure was different.

Also, in Portland the businesses work largely through a business association that aggregates the interests (at least on this topic) and works as one major supporter. In both cases it is only a few major supporters in each city. It's not the whole growth machine network, or a whole venture capitalist industry. There are relatively few actors who are important because they are the business interests in the town, but not because of the type of business interests. The scale of their businesses is relative anyway - smaller businesses have the same or equal access in smaller jurisdictions as larger businesses have in larger ones. The relationship between the businesses and the decision makers is fairly analogous in terms of the amount of influence.

The cities in this study have different political economic contexts, with San Francisco being a more interconnected global city and Portland being more similar to a smaller traditional growth machine city. These are important distinctions, and academic research would suggest they would be strong drivers of differences across the cases in this research. However, this research has found that in terms of local decision making on this issue, they are, in practice, rather similar. Having venture capitalists in your city might further push the political climate or structure to a more conservative/moderate one. In fact, this is the case now in San Francisco where VC Conway is funding 
moderate/conservatives to run for the board of supervisors in historically progressive districts, This will allow policy making at the board level to be more in line with business interests. The differences in tactics and language aren't because of where these venture capitalists sit in the global political economy, they're because of very local conditions.

Resources alone may not fully explain the choices in policy arenas, however. In addition to resources available, the different government structures in different cities also frame the opportunities for influence. The widespread use of the initiative and referendum process in California whereby citizens and elected officials can fairly easily put an issue on the ballot provided an opening for that as an option. In places where this is not an option, like in Portland, actors need to use different arenas to solve policy issues. The unique Portland context of a history of citizen involvement in decision making contributed to the choices of arenas available there. The resisters and their tactics vary because in part because of their mission and location in the local content including: (a) the history and development of the activist community and (b) the ability to be confrontational when receiving money from the city.

\section{Homelessness in Policy Discourse and Social Movement Framing}

Finding 4: Actors use different narratives to influence decision makers and each other, responding and shifting to competing frames over time. The guiding research question used to investigate policy discourse was: How do actors use policy discourses to influence decision makers? 
This research is based on the premise that policy debates are communicatively shaped by numerous actors working in different arenas to influence decision makers. As such, I tracked how language is used over time, finding that actors use different narratives to influence decision makers and each other, responding and shifting to competing frames over time, with some main frames described in Table 7. The change over time is important, as it shows how policy debates change based on influences from different actors. My findings suggest the framing of the original necessity for the policy can influence the policy trajectory, but actors can and do respond and successfully shift policy discourses over time. This is not a one-time process, but a process that is always in flux. These discursive shifts impact the thinking about the issue and the policy responses that are formulated.

Table 7: Collective Action Frames, by city

\begin{tabular}{|lll|}
\hline Actors & San Francisco & Portland \\
& & \\
\hline Messages of resisters & Sidewalks are for people; & Deserving poor \\
& rights to use sidewalks; & \\
& deserving poor & \\
\hline Messages of proponents & Dangerous deviants; & Protecting sidewalk access for \\
& & everyone; balancing needs of \\
& & community \\
\hline
\end{tabular}


The narratives that the actors use change over time in order to respond to others. For example, in both the Portland and San Francisco cases, the various actors have pushed and pulled between the deviance and deserving frames as a way to counter each other's argument and reframe the terms of the policy discussion. This finding was expected based on previous work on how homelessness is framed. It is also underlies the debate throughout time, though it does ebb and flow in centrality of focus, depending on other frames also being used.

One more surprising finding though was that how resistance actors talk about enforcement is very different in the two cities, and led to different approaches to countering criminalization language. The Portland idea of negotiation for more community oversight, and trusting the police to be discretionary is very different from the conversation about discretion in San Francisco. In San Francisco, discretion is the proof used to target homeless people. In Portland, discretion is what mitigates the effects and makes it acceptable. This is one of the largest differences between discourses in the two cities, and is indicative of how basic assumptions about the role of the police (as one example of the local context) influence the local policy options.

The framing also changes depending on who the actors are trying to influence. Supporters in both cases started by trying to influence decision makers in local government without engaging the wider public. However, once homeless advocates heard of the measures, they sought the power of the public by publicizing the proposals and framing them as unfairly targeting a vulnerable group. In both cases, the response by 
supporters is counter by trying to "other" the homeless by focusing on deviance. These different framings are important because policy making has unequal outcomes for different participants (Marston 2004). If outcomes were the same for all categories of people, policy decisions would be much easier. However, that is not the case. Therefore, policy makers must decide who wins and who loses, and in which ways they win or lose, for each policy. In these cases the decision impacts those with no access to private places to sit more than it impacts those with private space. It has long been established that the homeless by definition have no access to private spaces, and thus must live entirely in public (Cresswell, 1997). This is especially true in a context where most cities with large homeless populations, including both Portland and San Francisco, do not have enough shelter beds or public housing for all who need it. For many homeless then, all activities of daily life, including sitting and sleeping, are required to be done in public (Cresswell, 1997). Therefore, policies regulating these activities disproportionately affect the homeless. It makes sense then that policy discourse centers around the effect on this population. Supporters of these policies often try to limit this fact in their policy narratives by doing one of two things. They frequently either describe the homeless as the undeserving poor who are engaging in criminal activities, or they argue that the policies affect all people equally. Perhaps the most important task that homeless advocates continually attempt to accomplish is to keep the focus on the disproportionate impact on the homeless and reframe them as a dependent group, rather than a deviant one. This debate about dependency or deviance occurs in many policy debates around 
homelessness (Katz [1989]2013; Ingram \& Schneider 1993, 2007; Schneider, Chamberlain, Hodgetts 2010) and is prevalent in the sit/lie policy issue as well.

One significant discourse that is largely missing is that of pedestrianism. In Bloomly's study of professional planners in Canada, he found that most of the discourse around a similar policy was about keeping sidewalks clear for pedestrians (Bloomly 2010a, 2010b). This theme was present for a short period in the Portland case, but supporters moved to different frames fairly quickly as opposition was able to point out that the ability to walk through somewhere may not be as dire as the ability to sit down if you are disabled or have no place else to go.

Engaging the wider public in the issue, and removing it from one of bureaucratic decision making is a tactic that was used in both places that resisters used to counter this framing. It may have be effective because it opened up spaces for political debate, and allowed resisters to shift the language to the deserving homeless or removal of rights, something that resonates with a wider public more than technical planning language. Based on Bloomly's research, keeping the policy making to a narrower field of professional decision makers seems to encourage focus on pedestrianism or administrative re-writes that support law enforcement.

Pedestrianism seems to be an ineffective way to influence the general public, even though it may be very effective in influencing transportation officials and planners. This is not surprising given the research that finds that frames used by organizations are consistent with their "organizations core norms, values and beliefs," (Reese \& 
Newcombe, 2003). Thus, planners charged with segmenting uses of public spaces are likely to frame their opinions around the designated transportation use of sidewalks (getting around), while homeless advocates are more likely to frame their opinions around the impact on those they advocate for. It is interesting that the planning frame did not get widespread use as an approach by supporters or resisters in either the Portland or San Francisco cases, except for a short period of time in Portland.

\section{Conclusion for Theory}

Together, the analysis across these three domains helps explain how and why sit/ lie ordinances come to be, even in historically progressive cities such as Portland and San Francisco. Typically research would focus on just one of these domains, however this multidisciplinary approach to understanding these policies shows the interconnectedness. This approach relies on three main bodies of literature: (a) Neoliberalism and right-tothe-city theory, (b) the framing literature from social movements theory, and (c) interpretive policy analysis and the role of discourse in the policy process.

Each of these areas of research informs the issue of sit/lie ordinances. First, the research helps to frame the tensions in contemporary urban policy between the rise of a neoliberal policy environment on one hand, and the right-to-the-city movements on the other. Then, the social movements field of sociology and the interpretive policy tradition both focus on the role of discourse and narrative in structuring social action. The findings described above are summarized in table 8 below, by each domain. 
Table 8: Summary of Findings

\begin{tabular}{|c|c|c|c|}
\hline Domain & Guiding questions & Guiding proposition & Finding \\
\hline $\begin{array}{l}\text { Interpretive Policy } \\
\text { Analysis }\end{array}$ & $\begin{array}{l}\text { What happened and } \\
\text { when? In what } \\
\text { arenas do actions } \\
\text { occur? }\end{array}$ & $\begin{array}{l}\text { The type and length } \\
\text { of the policy } \\
\text { process influences } \\
\text { the types of actions } \\
\text { taken and the } \\
\text { different policy and } \\
\text { message outcomes. }\end{array}$ & $\begin{array}{l}\text { Political process } \\
\text { provides windows } \\
\text { of opportunity and } \\
\text { arenas for } \\
\text { activities. }\end{array}$ \\
\hline & $\begin{array}{l}\text { Who were actors } \\
\text { trying to influence? }\end{array}$ & $\begin{array}{l}\text { The type of process } \\
\text { used influences who } \\
\text { actors are trying to } \\
\text { sway, and thus their } \\
\text { messaging } \\
\text { strategies. }\end{array}$ & $\begin{array}{l}\text { The arena } \\
\text { influences the } \\
\text { depth to which } \\
\text { resisters can } \\
\text { discuss the issues } \\
\text { with the wider } \\
\text { public and } \\
\text { decision-makers. }\end{array}$ \\
\hline $\begin{array}{l}\text { Neoliberal/Right-to- } \\
\text { the-city Actors }\end{array}$ & $\begin{array}{l}\text { Who were the } \\
\text { actors? Who puts } \\
\text { the issue on the }\end{array}$ & $\begin{array}{l}\text { Actors vary } \\
\text { depending on the } \\
\text { city elite's location }\end{array}$ & $\begin{array}{l}\text { Local actors have } \\
\text { different positions } \\
\text { in the global }\end{array}$ \\
\hline
\end{tabular}




\begin{tabular}{|c|c|c|c|}
\hline & agenda? & $\begin{array}{l}\text { in the global } \\
\text { political economy } \\
\text { and/or the } \\
\text { development of } \\
\text { grassroots } \\
\text { organizing sectors. }\end{array}$ & $\begin{array}{l}\text { economy however } \\
\text { on the local level } \\
\text { their different } \\
\text { avenues and } \\
\text { strategies of } \\
\text { involvement are } \\
\text { due to local } \\
\text { conditions rather } \\
\text { than global ones. }\end{array}$ \\
\hline $\begin{array}{l}\text { Homelessness/social } \\
\text { movement framing }\end{array}$ & $\begin{array}{l}\text { How do actors use } \\
\text { policy discourses to } \\
\text { influence decision } \\
\text { makers? }\end{array}$ & $\begin{array}{l}\text { The different actors } \\
\text { may use different } \\
\text { messages. }\end{array}$ & $\begin{array}{l}\text { Actors use } \\
\text { different } \\
\text { narratives to } \\
\text { influence decision } \\
\text { makers and each } \\
\text { other, responding } \\
\text { and shifting to } \\
\text { competing frames } \\
\text { over time. }\end{array}$ \\
\hline
\end{tabular}

Taking these findings one step further, this research describes the interconnections between each of these domains. What was not yet fully understood is 
how these variations interact to create the policies in different cities. This research develops an explanatory theory through comparative case study of how those elements work.

Figure 3 below shows conceptually how these elements work together in the policy making process. The blue circle in the middle represents the policy making process, and each of the boxes inside are a key element that this research found to be important in explaining how and why events happened as they did. The four key elements in policy making were: the actors (neoliberal and right-to-the-city); the tactics used by the actors; the policy talk/collective action frames used by the actors; and the policy arenas. I found that these elements are interconnected in multiple ways. In figure 3 below the arrows are meant to highlight these observed relationships between the factors that are similar across multiple cases. This figure is a simplification of the descriptions of relationships that follow. 


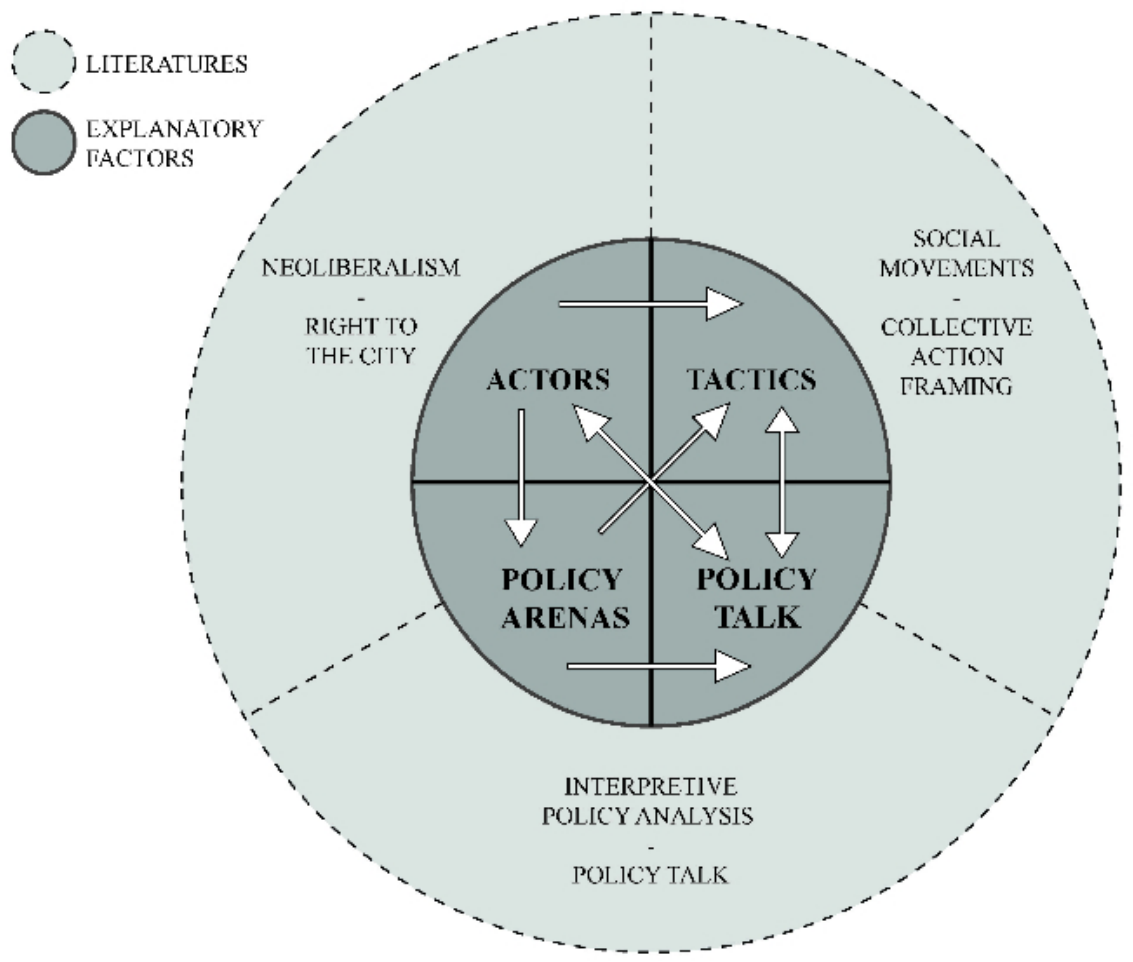

Figure 3: Theoretical Findings and Relationships

This section describes the connections between the explanatory factors, as simplified through the arrows above. First, who the actors are influences the types of tactics that they can use. For example, government officials have certain types of policy making in their control (i.e. the ability to call citizen committees or to put something on a council agenda). In another example, actors who rely on government funding may need to limit confrontational tactics in order to preserve their ability to provide much needed social services and so may need to access more cooperative tactics. In Portland, different nonprofit organizations employed different tactics based on their organizational missions and expertise. Those with a focus on civil rights took to legal strategies, and 
those focused on services were focused on getting the best possible social programs in place.

Second, the policy arenas influence the types of policy talk that can be used. For example, a city wide election relies on short messages that can reach a larger audience very quickly and efficiently while a collaborative process with a stakeholder group may allow for more nuanced, detailed analysis and persuasive argument. A citizen stakeholder committee can have much more nuanced arguments and room for back and forth than is possible with short communications with potential voters.

Next, and in a similar way that arenas influence policy talk, the policy arenas influence the tactics used as well. For example, as policy arenas change, tactics also need to evolve. For example, in San Francisco actors changed their tactics as the policy arena changed, they went from trying to influence the board of supervisors to conducting a door knocking campaign to influence voters as the decision making arena moved to a public election. Put perhaps a little over simply, door knocking campaigns are more useful in elections than stakeholder processes, and so resisters must be prepared to change approaches as any of these three explanatory factors (arenas, tactics, talk) evolve and change. These three also cannot be analyzed independently, as they influence choices of actors in an interdependent way. Policy arenas, policy talk, and tactics are connected in a three way triangle.

Fourth, this arrow describes the multi-directional influence that actors and policy talk have on each other. See for example, the call and response effect of different policy 
talk by different actors over time as described in earlier chapters. When one actor or set of actors advances the arguments through a specific thread of policy talk, other actors respond to that thread and try to counter or discredit that thread. This cycle of influence requires continual revision and adjustment of language over time as actors influence each other.

Finally, there are relationships between actors and selection of policy arenas. The cases show that actors can influence policy arenas in order to set themselves up to use more advantageous tactics and talk. Some actors may decide that they have more or less power in different arenas, based on their position in the local political economy, and other specific local factors as described in earlier chapters. In the next section I use these findings to highlight lessons for practice.

The larger political economy also plays a structuring effect on what is possible. One major factor is the changes that happen in cities due to the rise of roll out neoliberalism. Neoliberal policies are a powerful influence on the shape of the city, including poor people's experience of it. This includes a shift of the role of the state, from buffering the negative effects for those harmed by market forces, to a focus on partnering with private capital (Smith, 2002). Further, neoliberalism sees the role of the state as facilitating global capital, rather than redistributing wealth. This is a complete shift in the role of government, and is both an economic and a political project (Purcell, 2002; Brenner \& Theodore, 2002). This project and the associated political and 
economic structures are the structures that provide the context in which local actors make policy.

There have been at least two phases of the neoliberal project, called roll-back and roll-out neoliberalism (Brenner \& Theodore, 2002). The first, or roll-back phase, is usually associated with the Reagan and Thatcher administrations' focus on policies which "rolled-back" the social safety nets and programs for the poor. This was done by local, state, and national governments, but also on a global scale through World Bank/IMF austerity measures and structural adjustment regimens. The reduction of social safety nets is a prime reason that homeless people are living in public space. For example, the national housing policy in the united states that relies on a market-based approach leads to a situation where some people can not afford market rate housing and increases the instances of homelessness. This is a structure that underlies the context in which sit-lie ordinances are created; if people have no access to private space they must live in public, including on sidewalks.

The second phase, roll-out neoliberalism, is the rolling out of new policies that restructure the state to support the needs of global capital, such as policies that support gentrification and displacement of the poor. Quality of life laws such as sit-lie are an example of this second phase of roll-out neoliberalism. For example, especially in cities that rely on tourism as an economic driver, visible poverty is seen as problematic and something that local elites often want to control. This phenomenon of removing the 
visibly poor is prevalent in everyday life on sidewalks, and also during special events such as during mega events all over the world.

When both of these phases occur, we have a situation where the social service net is eroded, pushing poor people into public and causing conflicts over who can use public spaces for what uses. At the same time, it isn't the state's role to take care of them anymore. It isn't about having a stronger safety net, and we see increased use of criminalization. However, the resisters are able to make the case that a safety net is needed, and that criminalization is the wrong approach. As these conflicts are constructed, supporters are advancing roll out neoliberalism while contesters are attempting to redefine what is possible at the local level. Due to the advanced stages of neoliberalism, political fights tend to be relatively small - as the larger neoliberal agenda sets the context for the realm of what is possible. As such, resisters end up fighting for the rights to sit on the sidewalks, or for little changes such benches and day centers, and not the big things like a change in housing, labor, education, or health care policy that could potentially end the underlying need for poor people in live in public space.

\section{Implications for Practice}

The case studies and analysis presented in this research provide some potential lessons for practice both in the cities studied, and more generally for other cities. In both cases presented here the policy discourse has continued since the period covered by this research project, and in many ways the issue of homeless people's use of public space has become even more contentious. As inequality, rising housing costs, and stagnating 
wages become even more prevalent in cities in the US, these issues are likely to continue to be important contemporary policy questions. One aim of this research was to be able to contribute to these policy discussions by providing resisters lessons that they can incorporate into their strategies.

\section{Framing and Use of Policy Discourse}

Resisters may ask which framing and policy discourse has been most effective to date. This is a complicated answer because, as we have seen, the frames and discourses are highly dependent on the arenas of policy making and who needs to be convinced to make a decision. Indeed, this is the first lesson: the frame needs to be accessible to your audience. For example, in San Francisco while the organizers recognize the idea of the right to the city is important to their analysis of the situation, the message was too difficult to get across in a get-out-the vote strategy when they needed short sound bites with many voters rather than in-depth conversations with fewer decision-makers.

However, this frame might have been more effective if used in Portland during the longer stakeholder committee meetings where groups engaged in deeper, facilitated decisionmaking processes that focused on understanding the issue. Instead, resisters in Portland focused more on the need for services and the dependency of the vulnerable population, which is already a message that is fairly easy to get across and may not need more indepth conversations to explain. Some homeless advocates argued that there is no right to sit on the sidewalk, that sidewalks are for thoroughfares, indicating that there may not 
even be agreement among resisters about the validity of the right to the city claim as it stands, not even just as an effective strategy.

This choice of narratives may also help explain the reason that while right-to-thecity arguments are prevalent in academic research, they were fairly limited in use by practitioners for advocacy reasons. The concept is just too difficult to message in a short way to the public at large, so it is not an effective organizing tool.

Academics have made the strong case that outlawing the use of public spaces by the homeless for activities of daily life when there are no other options is essentially outlawing the ability to be. You have to be a person somewhere. The argument often found in the right-to-the-city literature specifically pertaining to homeless people is that since there are no private spaces available to them, homeless people do have rights to the sidewalk and other public spaces because they must sit somewhere.

\section{The Power of the Arena}

The study was designed as two case studies, but the finding of multiple phases of policy making within each offers an opportunity for multiple mini cases. The phases largely correspond to different arenas, offering the ability to look at how different arenas provide different opportunities for action. Strategic use of multiple different arenas in conjunction with each other may ultimately be the most effective, as described in the conceptual diagram as summarized in Figure 3 on page 148. 
One of the strategies most often used by supporters of sit/lie ordinances is to change the venue to arenas they can influence and are likely to be successful. For example, in San Francisco when supporters got resistance they changed arenas several times, from a very short lived citizen committee process, to the board of supervisors, and then to an election by voters. The changes in arenas came after finding resistance from homeless advocates, first through a strong initial opposition to the policy in early meetings with city staff, then to public days of action and testimony at public meetings to encourage the board of supervisors to vote it down.

Resisters also used this strategy of pushing a change of arenas, but to a more limited extent. For example, in Portland early resisters focused on pulling the issue out of an administrative or bureaucratic decision-making process into one that would allow for (or require) more public involvement. Their analysis was that policymakers in support of the issue would find it much easier to make changes without a big public process. They were concerned by allowing the issue to be purely a question of administration of current policy, changes could fly under the radar and go through relatively quickly. Activists, coupled with a Mayor that believed that public process is healthy and good worked to get these decisions in front of the public and then worked to shape public debate through a complex stakeholder citizen group. This strategy slowed down decision-making, but did not result in a long term solution that was supported by all sides. In fact, after nearly a decade of public debate in Portland, the city government 
made a move to pull the issue of sit/lie back into the bureaucratic policy-making realm where professionals would control and shape the policy and the discourses around it.

So while supporters are quick to change to arenas where they believe they can be successful, resisters could be more pro-active in trying to push the decision-making to other arenas that are more helpful for them. This solution will be highly context dependent, however it may be, for example, that if a collaborative stakeholder process isn't working a shift to a lawsuit or protest or election may be more effective. There are also some risks to shifting arenas. For example, while the shift to a stakeholder process was a useful way in Portland to draw attention to the issue and slow down decisionmaking, participating in such a process can provide extra legitimacy to the eventual decision that may limit opposition in the future.

The choice to participate in a stakeholder committee or other public process may come with a loss of political power. Some researchers have found that formal stakeholder groups are sometimes used to further "co-opt [...] claims to exclusion" by including resisters and using their participation to legitimize the process and outcome (Lee, 2007 p.90). Resisters should be wary that their participation could be seen to give more legitimacy to an outcome, as was the case in the Portland SAFE committee process. The Portland case also suggests that the agenda as formally set by the convener determines strongly the agenda of the meeting, and places a focus on a particular framing of the issue which leads to a particular set of solutions. The framing of the process may 
be difficult to change from within the process, and may need to use protest or outside forms of advocacy to shift.

The approaches vary depending on who resisters were trying to influence, resources available to fund strategies, and to some extent the historical or cultural differences of a place (like the Portland way of getting into dialogue with opposing viewpoints to find points of agreement, or San Francisco's strong tradition of holding days of action and protest actions). These different repertoires of contention shape in part what strategies activists come to rely on, and the strategies vary by place. The lesson here is that resisters should continue to think strategically not only about which messages are most effective, but about opportunities to change arenas in order to change who you have to influence and how they respond to different messages.

\section{Final Notes on Success}

Resisters in both cities also raised the issue of how to define success. Part of this analysis of what would be most effective is to define what we mean by effectiveness and what resisters consider success to be. When looking at resister's own words, they define winning as making advancements in how the public perceives the issues and public support.

For example, in San Francisco the law banning sitting and lying on sidewalks did pass. However, resisters call this a win because the final vote was much closer than what the initial polling had suggested it would be. When they started the campaign, polls had 
the law passing by a much larger margin. They felt they made gains because they were able to convince more people to change their mind.

Throughout interviews with practitioners who work in this field, there is a lot of pessimism about what is possible, and the extent and size and scope of the problem and what can be done on the local level. So part of what they are trying to do is to hold off these roll out policies. And they're mad that they have to spend their time fighting for someone's right to sit on the sidewalk, and not use that time to fight for someone's right to more housing, or better jobs, or structural changes that would really make a difference.

However, resisters report that this fight has to be done because it has such a negative impact on day to day quality of life of people living on the streets, and increased criminalization makes the situation worse by adding to barriers to getting employment, housing and health care. While the people who have power to set the political agenda keep putting it on the agenda, resisters will need to keep resisting. While the refusal of supporters to agree to interviews means limited data available on their intentions, it well may be an intentional strategy of the supporters to keep resisters focused on this relatively minor and super local issue, rather than being able to use their energy to fight for larger changes in the political economy that would actually solve the issue of homelessness.

The current political and economic climate in both cities were very challenging for those who work with and advocate for people who are homeless. For them, they report that while stopping a sit/lie law is important; changing the policy discourse more 
broadly to support the needs of their constituents may be more important in the long term. For them, winning is not just about stopping the policy, but with changing minds and raising awareness. With a longer-term organizing strategy of building power and changing the system, they're (maybe over optimistically) looking for wins in building awareness, or losing by a smaller margin than they did in the past. They realize they can't win every battle, but they are organizing for the larger war. For them, fighting for the right to sit or lie on the sidewalk is not the end goal. The end goal is to find approaches to homelessness that solve the problem by providing housing, wages, healthcare, and opportunities for dignity and respect in society. Fighting sit/lie is just one portion of that.

\section{Future Research}

This project has helped to describe the resistance of right to the city actors against roll-out neoliberalism policies, using the example of the policy processes around sit/lie ordinances in two case studies. I have developed a theoretical framework on the ways in which different elements of policy talk, policy actors, and policy arenas influence these policy processes. There are three areas of future research that are needed to continue this research trajectory.

First, there is a need to test this multi-disciplinary framework that was developed in a specific type of policy process with other policies. One next step is to look at adjacent policy issues, such as urban camping and the use of tents in public space by those who are homeless. Just as laws against sitting and lying have increased in the past 
decade in the United States, there has also been an increase in policies regulating camping. Additional research needs to focus on what similarities and differences exist in policy processes around sit/lie and anti-camping laws, as well as more investigation about what drives those differences. Such work could further strengthen theory about how right to the city movements work in practice at the local level.

Second, more research on supporters of these laws and others is needed. As is the case in other research projects, this research was not able to include interview data from elites that supported the laws for the reasons described in the methods chapter. While the observed actions are integrated into the analysis here, more understanding of how and why they choose those actions and the decision-making behind them would be helpful for building theory, just as the answers to those questions for resisters was used here.

Finally, additional research with an explicit look at race and gender in the policymaking process around sit/lie is needed. Language on gender and race were largely missing from the public record, but are both important aspects to understanding the regulation of bodies in public space. Future research on a masculinized conceptualization of public space and its impact on criminalization policies is important. It is possible that the focus on largely male subpopulations and the repeated themes of aggression, deviance, and criminality may be linked.

Additional research focusing specifically on a gendered analysis of targets of criminalization policies as well as enforcement strategies, may help both further explain the appearance of aggression in the policy language around sit-lie and provide additional 
insights into approaches for resistance. Similarly, future analysis about race could be conducted by incorporating an analysis of images used alongside stories or in visual media campaigns, data currently unavailable for this project. 


\section{References}

2011 Greater Los Angeles Homeless Count Report. (2011). Los Angeles: Los Angeles Homeless Services Authority.

2011 Point-In-Time Count of Homelessness in Portland/Multnomah County, Oregon. (2011). Portland: Kristina Smock Consulting.

2011 San Francisco Homeless Point-in-time Count \& Survey: Executive Summary and Comprehensive Report. (2011). San Francisco, CA: City and County of San Francisco and Applied Survey Research.

Abbott, C. (2001). Greater Portland: Urban Life and Landscape in the Pacific Northwest. Philadelphia: University of Pennsylvania Press.

Altheide, D. (1996). Qualitative media analysis. Thousand Oaks: Sage Publications.

Beckett, K., \& Herbert, S. (2008). Dealing with Disorder: Social Control in the PostIndustrial City. Theoretical Criminology, 12(8), 5-30.

Benford, R. D., \& Snow, D. A. (2000). Framing Processes And Social Movements: An overview and Assessment. Annual Review of Sociology, 26(1), 611.

Blomley, N. (2010a). Rights of Passage: Sidewalks and the Regulation of Public Flow. New York: Routledge.

Blomley, Nicholas. (2010b). The Right to Pass Freely: Circulation, Beggign, and the Bounded Self. Social \& Legal Studies, 19(3), 331-350. Blumenberg, E., \& 
Ehrenfeucht, R. (2008). Civil liberties and the regulation of public space: the case of sidewalks in Las Vegas. Environment and Planning A, 40, 303-322.

Blumenberg, E., \& Ehrenfeucht, R. (2008). Civil liberties and the regulation of public space: the case of sidewalks in Las Vegas. Environment \& Planning A, 40(2), 303-322.

Braun and Clarke. (2006). Using thematic analysis in psychology. Qualitative Research in Psychology. 3: 77-101

Brenner, N. and Theodore, N. (2002). Cities and the Geography of "Actually Existing Neoliberalism.” Antipode

Bogard, C. (2003). Seasons such as these: how homelessness took shape in America.

Carragee, K. M., \& Roefs, W. (2004). The Neglect of Power in Recent Framing Research. Journal of Communication, 54(2), 214-233. doi:10.1111/j.14602466.2004.tb02625.x

Corrigall-Brown, C., Snow, D. A., Smith, K., \& Quist, T. (2009). Explaining the Puzzle of Homeless Mobilization: An Examination of Differential Participation. Sociological Perspectives, 52(3), 309-335.

Cronley, C. (2010). Unraveling the Social Construction of Homelessness. Journal of Human Behavior in the Social Environment, 20(2), 319-333. doi:10.1080/10911350903269955 
Cress, D. M., \& Snow, D. A. (2000). The Outcomes of Homeless Mobilization: The Influence of Organization, Disruption, Political Mediation, and Framing. American Journal of Sociology, 105(4), 1063-1104.

Creswell, J. W. (2003). Research Design: Qualitative, Quantitative, and Mixed Methods Approaches (2nd ed.). Thousand Oaks: Sage Publications, Inc.

Cresswell, T. (1997). Weeds, Plagues, and Bodily Secretions: A Geographical Interpretation of Metaphors of Displacement. Annals of the Association of American Geographers, 87(2), 330-345.

Currie, C. (2002, September 5). In My Opinion Arresting Homeless is no Solution to Their Problems. The Oregonian, p. D13. Portland, OR.

Davis, M. (1992). Fortress Los Angeles: the militarization of urban space. In M. Sorkin (Ed.), Variations on a theme park: the new American city and the end of public space (pp. 252). New York: Hill and Wang.

DeLeon, R. E. (1992). Left Coast City: Progressive politics in San Francisco, 1975-1991. Lawrence: University Press of Kansas.

Del Casino, V. J., Jr, \& Jacoy, C. L. (2008). Intervention: Neoliberal subjectivities, the 'new' homeless, and struggles over spaces in/of the city. Antipode: A Journal of Radical Geography, 192-199. 
DePastino, T. (2003). Citizen hobo : how a century of homelessness shaped America. Chicago :: University of Chicago Press.

Ehrenfeucht, R., \& Loukaitou-Sideris, A. (2007). Constructing the sidewalks: municipal government and the production of public space in Los Angeles, California, 18801920. Journal of Historical Geography, 33, 104-124.

Fairclough, N. (2006). Critical Analysis of Media Discourse. In P. Marris \& S. Thornham (Eds.), Media Studies: A reader (2nd ed., pp. 308-325). New York: New York University Press.

Fischer, F. (2003). Reframing Public Policy: Discursive Politics and Deliberative Practices. Oxford: Oxford University Press.

Fischer, F., \& Forester, J. (1993). The Argumentative turn in policy analysis and planning. Durham, N.C. : Duke University Press.

Floersch, J., Longhofer, J., Kranke, D., \& Townsend, L. (2010). Integrating Thematic, Grounded Theory and Narrative Analysis: A case study of adolescent psychotropic treatment. Qualitative Social Work, 9(3), 407-425.

Fopp, Rodney. (2009). Metaphors in Homelessness Discourse and Research: Exploring "Pathways", "Careers" and "Safety Nets". Housing, Theory \&amp; Society, 26(4), 271-291 
Flyvbjerg, B. (2011). Case study. Chapter 17, pgs. 301-316 In Norman K Denzin and Yvonna S Lincoln, eds. The Sage Handbook of Qualitative Research, $4^{\text {th }}$ Edition. Thousand Oaks, CA: Sage.

Gibson, T. (2004). Securing the Spectacular City: The politics of revitalization and homelessness in Downtown Seattle. Lanham: Lexington Books.

Green, A. (2004, June 24). Sidewalk-Blocking Ban Rejected. The Oregonian, p. D01. Portland, OR.

Green, A. (2009, June 23). Sit-lie Law Ruled Unconstitutional. The Oregonian. Portland, OR.

Griffin, A. (2006, May 24). City Plans to Extend Then Review "sit-lie" law. The Oregonian, p. E01. Portland, OR.

Griffin, A. (2007, May 2). Council recasts loitering rules. The Oregonian.

Habermas, J. (2006 [1989]). The Public Sphere. In P. Marris \& S. Thornham (Eds.), Media Studies: A reader (2nd ed., pp. 92-97). New York: New York University Press.

Hackworth, J. (2007). The neoliberal city: governance, ideology, and development in American urbanism. Ithaca: Cornell University Press.

Hajer, M., \& Wagenaar, H. (2003). Deliberative Policy Analysis: Understanding Governance in the Network Society. Cambridge: Cambridge University Press. 
Hall, S. (2006). Racist Ideologies and the Media. In P. Marris \& S. Thornham (Eds.), Media Studies: A reader (2nd ed., pp. 271-282). New York: New York University Press.

Hartman, C. (2002). City for Sale: The transformation of San Francisco (2nd ed.). Berkeley: University of California Press.

Harvey, D. (2003), The right to the city. International Journal of Urban and Regional Research, 27: 939-941

Harvey, D. (2008). The right to the city, New Left Review, 53(Sept - Oct), pp. 23-40.

Herbert, S. (2001). Policing the contemporary city: fixing broken windows or shoring up neo-liberalism? Theoretical Criminology, 5(4), 445-466.

Herbert, S., \& Brown, E. (2006). Conceptions of Space and Crime in the Punitive Neoliberal City. Antipode: A Journal of Radical Geography, 755-777.

Heying, C. (2010). Brew to Bikes: Portland's Artisan Economy. Portland: Ooligan Press.

Holland, W. W. (2009). Who is my neighbor?: Framing Atlanta's movement to end homelessness, 1900--2005. ProQuest Dissertations and Theses, 409.

Homeless, T. N. C. f. t., \& Poverty, T. N. L. C. o. H. a. (2006). A Dream Denied: The Criminalization of Homelessness in U.S. Cities.

Homes not Handcuffs: The Criminalization of Homelessness in U.S. Cities. (2009).). Washington DC: The National Coalition for the Homeless 
The National Law Center on Homelessness and Poverty.

Innes, J., \& Booher, D. E. (2003). Collaborative policymaking: governance through dialogue. In M. Hajer \& H. Wagenaar (Eds.), Deliberative Policy Analysis: Understanding Governance in the Network Society (pp. 113-138). Cambridge: Cambridge University Press.

Innes, Judith E. (1995). Planning Theory's Emerging Paradigm: Communicative Action and Interactive Practice. Journal of Planning Education and Research, 14(3), 183189.

Ingram, H., \& Schneider, A. (1993). Constructing Citizenship: The Subtle Messages of Policy Design. In H. Ingram \& S. R. Smith (Eds.), Public Policy for Democracy (pp. 68-94). Washington DC: The Brookings Institution.

Ingram, H., Schneider, A. L., \& deLeon, P. (2007). Social Construction and Policy Design. In P. A. Sabatier (Ed.), Theories of the Policy Process (2 ed., pp. 93-126).

Jacobs, K. (2006). Discourse Analysis and its Utility for Urban Policy Research. Urban Policy and Research, 24(1), 39-52.

Jacobs, J. (1961). The death and life of great American cities. [New York]: Random House.

Jacobs, K, \& Manzi, T. (1996). Discourse and policy change: the significance of language for housing research. Housing Studies, 11(4), 543-560. 
Johnson, S. R. (2004). The Myth and Reality of Portland's Engaged Citizenry and Process-Oriented Government. In C. Ozawa (Ed.), The Portland Edge: Challenges in Growing Communities. Washington, DC: Washington, DC : Island Press.

Katz, M. B. ([1989] 2013). The undeserving poor : from the war on poverty to the war on welfare. New York: New York : Pantheon Books.

Keil, R. (1998). Los Angeles: Globalization, Urbanization and Social Struggles. Chichester: John Wiley \& Sons.

King, Brayden. (2008). A Social Movement Perspective of Stakeholder Collective Action and Influence. Business and Society, 47(1), 21-49.

Knight, H. (2010a, March 2). Mayor to introduce 2 plans for sit/lie law to clear sidewalks. The San Francisco Chronicle, p. A1. San Francisco, CA.

Knight, H. (2010b, September 19). Groups Stand Up Against Sit-lie Law. The San Francisco Chronicle, p. C1. San Francisco, CA.

Knight, H. (2010c, October 19). CAMPAIGN 2010 Propositions L and M; Measure and “poison” counterpart divide SF. The San Francisco Chronicle, p. C1. San Francisco, CA.

Knight, H. (2010d, November 3). Prop. B rejected - controversial sit/lie L passes. The San Francisco Chronicle, p. A12. San Francisco, CA. 
Knight, H., \& Cote, J. (2010, April 6). Sit/lie Campaign Drawing Attention Even in Britain. The San Francisco Chronicle, p. C1. San Francisco, CA.

Kohn, M. (2004). Brave new neighborhoods: the privatization of public space. New York: Routledge.

Learn, S., \& Oliver, G. (2002, January 24). City Mulls Loitering Crackdown. The Oregonian, p. B01. Portland, OR.

Lee, C. (2007). Is There a Place for Private Conversation in Public Dialogue? Comparing Stakeholder Assessments of Informal Communication in Collaborative Regional Planning. American Journal of Sociology, 113(1), 41-96.

Leeson, F. (2002, August 16). City Backs Away From Writing Loitering Rule. The Oregonian, p. C03.

Lefebvre, H. (1996). Writings on Cities (E. Kofman and E. Lebas, Trans.). Cambridge, Mass: Blackwell Publishers.

Lofland, L. (1998). The public realm: exploring the city's quintessential social territory. Hawthorne N.Y.: Aldine de Gruyter

Loukaitou-Sideris, A., \& Ehrenfeucht, R. (2009). Sidewalks: Conflict and Negotiation over Public Space. Cambridge: The MIT Press.

Low, S. (2006). The politics of public space. New York: Routledge. 
MacLeod, Gordon and Kevin Ward. (2002) Spaces of Utopia and Dystopia: Landscaping the Contemporary City. Geogr. Ann., 84 B (3-4): 153-170

Marris, P., \& Thornham, S. (2006). Ideology and Discourse Introduction. In P. Marris \& S. Thornham (Eds.), Media Studies: A reader (2nd ed., pp. 267-269). New York: New York University Press.

Marston, G. (2004). Social Policy and Discourse Analysis: Policy Change in Public Housing. Burlington, VT: Ashgate Publishing Company.

Matthews, P. (2010). Mind the gap? The persistence of pathological discourses in Urban regeneration policy. Housing, Theory and Society, 27(3), 221-240.

Mayer, M. (2010). Punishing the Poor - a debate: Some questions on Waquant's theorizing the neoliberal state. Theoretical Criminology, 14(1), 93-103.

McAdam, D. (1996). Conceptual origins, current problems, future directons. In D. McAdam, J. McCarthy, \& M. Zald (Eds.), Comparative perspectives on social movements: Political opportunities, mobilizing structures, and cultural framings. Cambridge: Cambridge University Press.

McCarthy, J., \& Zald, M. (2006). The enduring vitality of the resource mobilization theory of social movements. In J. Turner (Ed.), Handbook of Sociological Theory. Springer Science \& Business Media. 
McCombs, M., \& Shaw, D. (2009). The Agenda-Setting Function of Mass Media. In K. Krippendorff \& M. A. Bock (Eds.), The Content Analysis Reader (pp. 99-105). Los Angeles: Sage Publications, Inc.

McVeigh, R., Myers, D. J., \& David, S. (2004). Corn, Klansmen, and Coolidge : Structure and Fr aming in Social Movements. Social Forces, 83(2), 653-690. https://doi.org/10.1353/sof.2005.0019

Meyer, D. S. (2002). Opportunities and Identities: Bridge-Building in the Study of Social Movements. In D. S. Meyer, N. Whittier, \& B. Robnett (Eds.), Social Movements: Identity, Culture, and the State. New York: Oxford University Press.

Mitchell, D. (1997). The annihilation of space by law: The roots and implications of the anti-homeless laws in the united states. Antipode: A Journal of Radical Geography, 29(3), 303-335.

Mitchell, D. (2003). The right to the city: social justice and the fight for public space. New York: Guilford Press.

Morgen, S. (2002). The politics of welfare and poverty research. Anthropological Quarterly, 75(4), 745-757.

Murphy, S. (2009). "Compassionate" strategies of managing homelessness: postrevanchist geographies in San Francisco Antipode: A Journal of Radical Geography, 41(2), 305-325. 
Nakamura, M. (2002, September 19). Protest Takes Stand For Sitting On Sidewalks. The Oregonian, p. D03.

Nevius, C. W. (2009, December 19). It's time to get tough on toughs in Haight. The San Francisco Chronicle, p. C1. San Francisco, CA.

Nevius, C. W. (2010a, February 27). Haight Walk Converts Newsom to Sit/lie. The San Francisco Chronicle, p. C1. San Francisco, CA.

Nevius, C. W. (2010b, May 11). Backers Must Stand/Shout in Face of Sit/lie Opposition. The San Francisco Chronicle, p. C1. San Francisco, CA.

Newman, K., \& Massengill, R. P. (2006). The Texture of Hardship: Qualitative Sociology of Poverty, 1995-2005. Annual Review of Sociology, 32, 423-446.

Noy, Darren. (2009). When Framing Fails: Ideas, Influence, and Resources in San Francisco's Homeless Policy Field. Social Problems, 56(2), 223-242.

Oliver, P. E., \& Meyer, D. J. (1999). How Events Enter the Public Sphere: Conflict, Location, and Sponsorship in Local Newspaper Coverage of Public Events. American Journal of Sociology, 105(1), 38-87.

Parker, S., \& Fopp, R. (2004). 'I'm the Slice of Pie that's Ostracized ...'. Foucault's Technologies, and Personal Agency, in the Voice of Women who are Homeless, Adelaide, South Australia. Housing, Theory and Society, 21(4), 145-154. doi:10.1080/14036090410011415 
Pimpare, S. (2004). The New Victorians: Poverty, Politics, and Propaganda in Two Gilded Ages. New York: The New Press.

Pimpare, S. (2008). A People's History of Poverty in America. New York: The New Press.

Pimsleur, J. L. (1992, August 27). Police Commission Reverses Its New Policy on Street Sweeps. The San Francisco Chronicle, p. A20. San Francisco, CA.

Piven, F. F., \& Cloward, R. A. (1977). Poor People's Movements: Why they succeed, how they fail. New York: Pantheon Books.

Piven, F. F. (2002). Welfare Policy and American Politics. In F. F. Piven, J. Acker, M. Hallock \& S. Morgen (Eds.), Work, Welfare and Politics (pp. 19-34). Eugene: University of Oregon Press.

Piven, F. F. (2010). A response to Wacquant. Theoretical Criminology, 14.

Portland City Council, Portland City Council Sess. (2007).

Portland City Council Meeting, (2007).

Potter, T., Rubio, M., \& Reynolds, S. (2006). Street Access for Everyone: Recommendations of the SAFE Workgroup. Portland: City of Portland.

Purcell, Mark (2002). Excavating Lefebvre: The right to the city and its urban politics of the inhabitant. GeoJournal 58: 99-108 
Reese, Ellen, \& Newcombe, Garnett. (2003). Income Rights, Mothers' Rights, or Workers' Rights? Collective Action Frames, Organizational Ideologies, and the American Welfare Rights Movement. Social Problems, 50(2).

Rein, \& Schon. (1993). The Argumentative turn in policy analysis and planning. In F. Fischer \& J. Forester (Eds.). Durham, N.C. : Duke University P

Rose, J. (2002, September 20). Street Beat: Claustrophobic Juror Ends Up In A County Jail Cell For A Day. The Oregonian, p. E02.

Rose, J. (2006, December 10). A better plan for vagrancy? The Oregonian, p. C01.

Rose, J. (2006b, December 14). Portland Set to Give "sit-lie" Law the Boot. The Oregonian, p. B02. Portland, OR.

Ryan, C., \& Gamson, W. a. (2006). The Art of Reframing Political Debates. Contexts, 5(1), 13-18. https://doi.org/10.1525/ctx.2006.5.1.13

Sabatier, P. (2000). Theories of the policy process. Journal of European Public Policy, $7(1), 135-140$.

Sabatier, P. A. (Ed.) (2007). Theories of the policy process (2nd ed. ed.). Boulder, Colo.: Boulder, Colo. : Westview Press.

Sandalow, M. (1993, December 10). D.C. Group for Homeless Criticizes Jordan's Matrix Program. The San Francisco Chronicle, p. D3. San Francisco, CA.

Sandberg, Sveinung. (2006). Fighting Neo-liberalism with Neo-liberal Discourse: ATTAC Norway, Foucault and Collective Action Framing, 5(3), 209-227. 
Schneider, Barbara, Chamberlain, Kerry, \& Hodgetts, Darrin. (2010). Representations of Homelessness in Four Canadian Newspapers: Regulation, Control and Social Order. Journal of Sociology \& Social Welfare, XXXVII(4).

Schneider, A., \& Ingram, H. (1993). How the Social Construction of Target Populations Contributes to Problems in Policy Design. Policy Currents, 3(1).

Shlay, A. B., \& Rossi, P. H. (1992). Social Science Research and Contemporary Studies of Homelessness. Annual Review of Sociology, 18, 129-160.

Smith, N. (1996). The New Urban Frontier: Gentrification and the revanchist city. London: Routledge.

Smith, N. (1998). Giuliani Time: The Revanchist 1990s. Social Text(57), 1-20. doi: $10.2307 / 466878$

Smith, Neil. (2002) New Globalism, New Urbanism: Gentrification as Global Urban Strategy. Antipode.

Snow, D. A., Soule, S. A., \& Kriesi, H. (2004). The Blackwell companion to social movements. Malden, MA: Malden, MA : Blackwell Pub.

Sorensen, A., \& Sagaris, L. (June 01, 2010). From Participation to the Right to the City: Democratic Place Management at the Neighbourhood Scale in Comparative Perspective. Planning Practice and Research, 25, 3, 297-316.

Staeheli, L. A. (2010). Political geography: democracy and the disorderly public. Progress in Human Geography, 34(1), 67-78. doi:10.1177/0309132509105006 
Staeheli, L., \& Mitchell, D. (2008). The People's Property? Power, Politics, and the Public. New York: Routledge.

Stern, H. (2002, October 28). Mayor: Money Key to Luring Jobs. The Oregonian, p. D01. Portland, OR.

Stern, H. (2003). Police Shut Down Peace Camp Across From City Hall. The Oregonian, p. B02.

Stinchcombe, A. (1963). Institutions of Privacy in the Determination of Police Administrative Practice. American Journal of Sociology, 69(2), 150-160.

Stone, D. (2001). Policy Paradox: The art of political decision making (3rd ed.): W.W. Norton \& Company.

Susser, I. (1996). The Construction of Poverty and Homelessness in US Cities Annual Review of Anthropology, 25, 411-435.

Swyngedouw, E. (1997). Neither global nor local: "Glocalization" and the politics of scale. In K. R. Cox (Ed.), Spaces of Globalization (pp. 137-166). New York: Guilford Press.

Tarrow, S. (1994). Power in Movement: Social Movements, Collective Action and Politics. Cambridge: Cambridge University Press.

The San Francisco Chronicle. (2010a, January 28). Urban Fear and Loathing. The San Francisco Chronicle, p. A15. San Francisco, CA. 
The San Francisco Chronicle. (2010b, October 9). Sit/lie Concerns - No Paranoid Fantasy. The San Francisco Chronicle, p. A9. San Francisco, CA.

The San Francisco Chronicle. (2010c, October 24). Best people, ideas to move forward; THE CHRONICLE RECOMMENDS In San Francisco. The San Francisco Chronicle, p. E8. San Francisco, CA.

Torgenson, D. (2003). Democracy through policy discourse. In M. Hajer \& H. Wagenaar (Eds.), Deliberative Policy Analysis: Understanding Governance in the Network Society (pp. 113-138). Cambridge: Cambridge University Press.

Van Gorp, B. (2007). The Constructionist Approach to Framing: Bringing Culture Back In. Journal of Communication, 57(1), 60-78. doi:10.1111/j.14602466.2006.00329.x

Vogel, N. (2009, December 19). Haight's bullies. The San Francisco Chronicle, p. A9. San Francisco, CA.

Wacquant, L. (2001). The penalisation of poverty and the rise of neo-liberalism. European Journal on Criminal Policy and Research, 9, 401-412.

Wacquant, L. (2012). Three steps to a historical anthropology of actually existing neoliberalism. Social Anthropology, 20(1), 66-79.

Waldron, J. (1991). HOMELESSNESS AND THE ISSUE OF FREEDOM. Ucla Law Review, 39(2), 295-324. 
Watson, S. (1984). Definitions of homelessness: a feminist perspective. Critical Social Policy, 4(60), 60-73.

Widdowfield, Rebekah. (2001). Beggars, Blaggers And Bums? Media Representations of Homeless People. British Academy Review.

Williams, J. C. (2005). The Politics of Homelessness: Shelter Now and Political Protest. Political Research Quarterly, 58(3), 497-509.

Wacquant, L. (2001). The penalisation of poverty and the rise of neo-liberalism. European Journal on Criminal Policy and Research, 9, 401-412.

Wacquant, L. (2012). Three steps to a historical anthropology of actually existing neoliberalism. Social Anthropology, 20(1), 66-79.

Whyte, W. (1980). The social life of small urban spaces. Washington D.C.: Conservation Foundation.

Wright, J. D., Rubin, B. A., \& Devine, J. A. (1998). Beside the Golden Door: Policy, Politics, and the Homeless. New York: Aldine De Gruyter.

Wright, T. (1997). Out of place : homeless mobilizations, subcities, and contested landscapes. Albany :: State University of New York Press.

Yin, R. (1984) Case Study Research: Design and Methods. Thousand Oaks: Sage Publications, Inc. 
Yin, R. (2003). Case Study Research: Design and Methods. Third Edition. Thousand Oaks: Sage Publications, Inc. 